\title{
REDOX-ACTIVE BIOINSPIRED CATALYSTS - SYNTHESES, CHARACTERISATION AND AN APPLICATION
}

PhD Dissertation

ZITA CSENDES

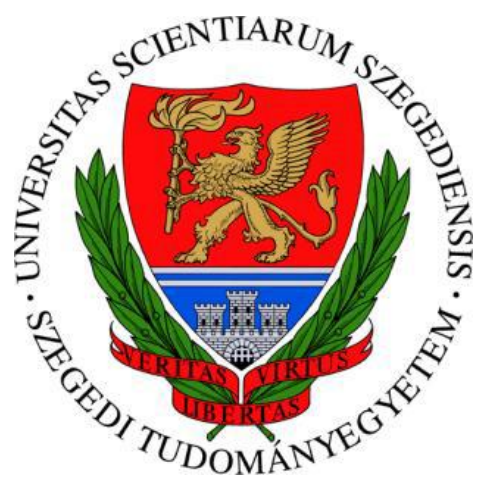

Supervisors: DR. ISTVÁN PÁLINKÓ

DR. PÁL SIPOS

Doctoral School of Chemistry

Material and Solution Structure Research Group

Department of Organic Chemistry

Department of Inorganic and Analytical Chemistry

Faculty of Science and Informatics | University of Szeged

Szeged

2014 


\section{Table of contents}

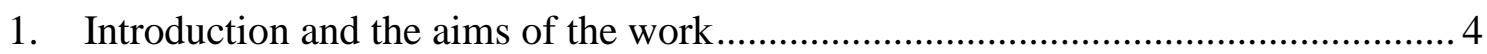

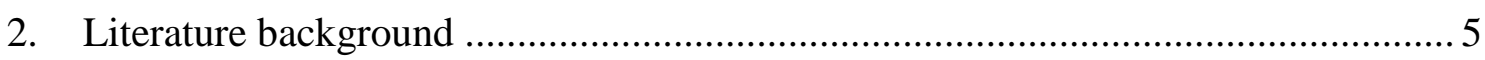

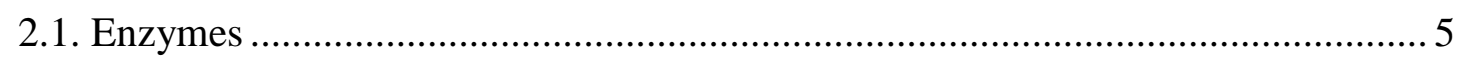

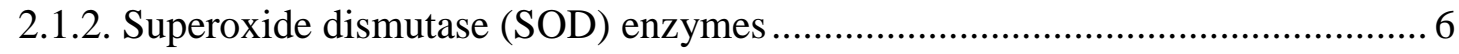

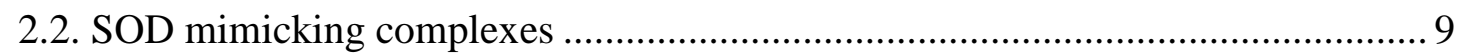

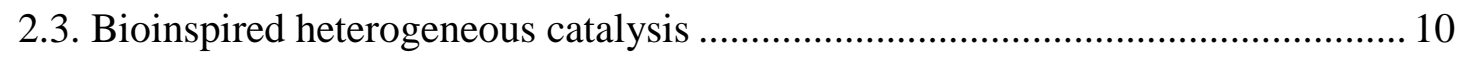

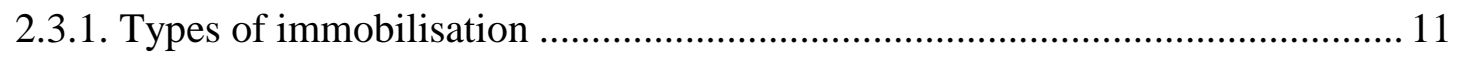

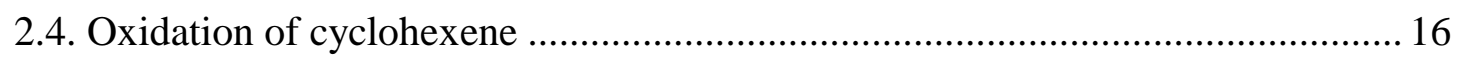

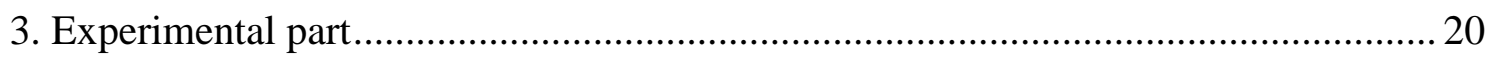

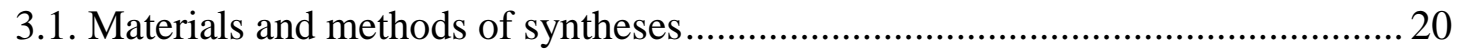

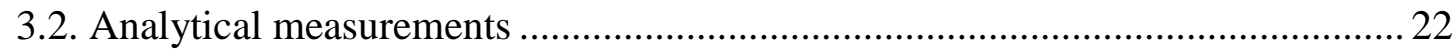

3.3. UV-Vis diffuse reflectance spectroscopy ....................................................... 22

3.4. Electron paramagnetic resonance (EPR) measurements ................................... 23

3.5. X-ray absorption spectroscopy (XAS) measurements ...................................... 23

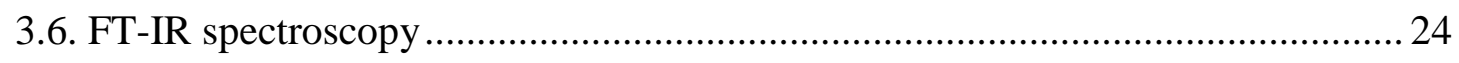

3.7. Testing the superoxide dismutase activity …..................................................... 25

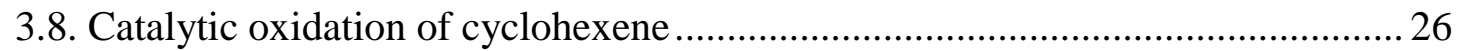

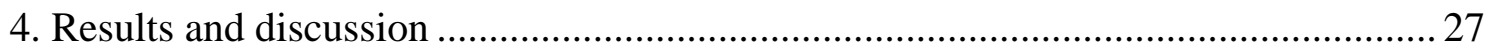

4.1. Mid IR spectra of the anchored and non-anchored ligands.............................. 27

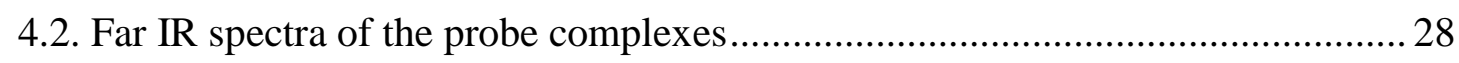

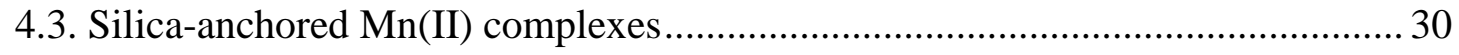

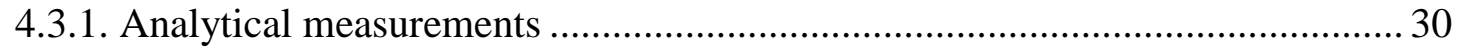

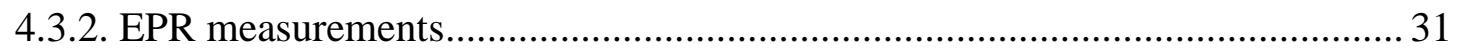

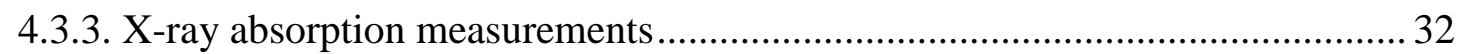

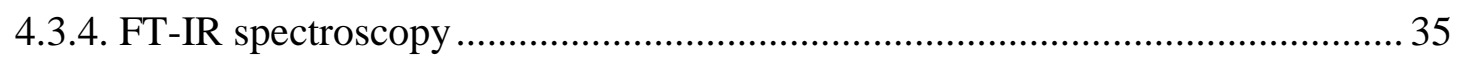

4.3.5. Testing the superoxide dismutase activity ................................................... 44

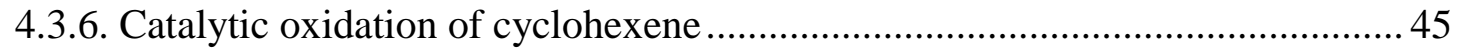

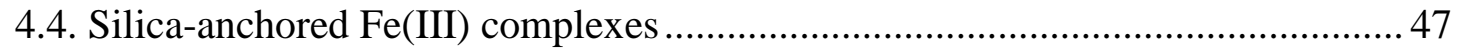

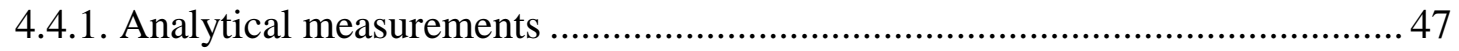

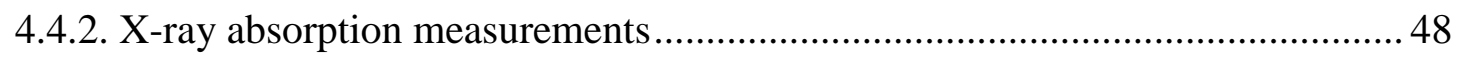

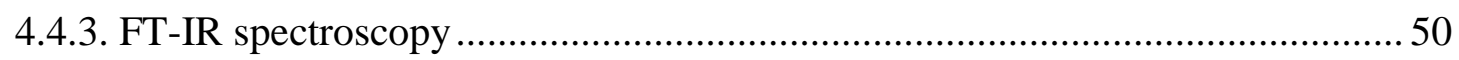




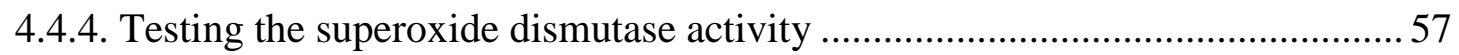

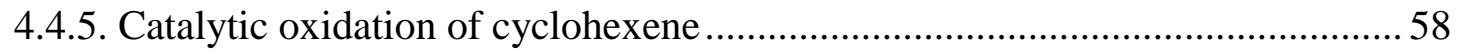

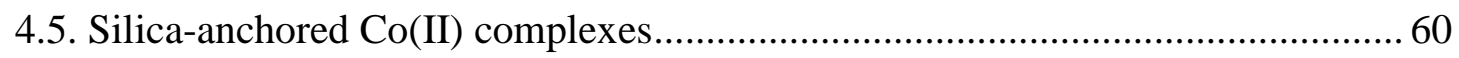

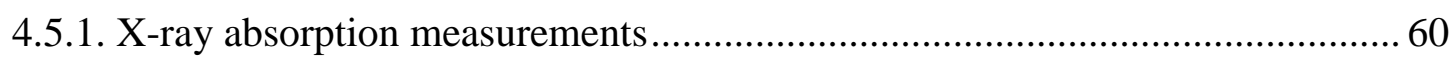

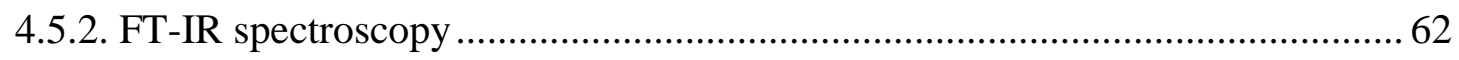

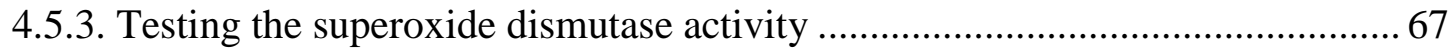

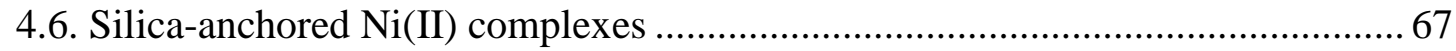

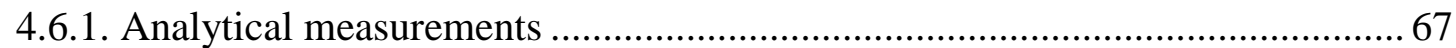

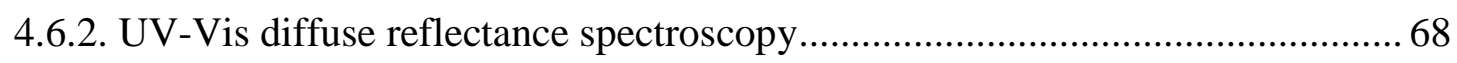

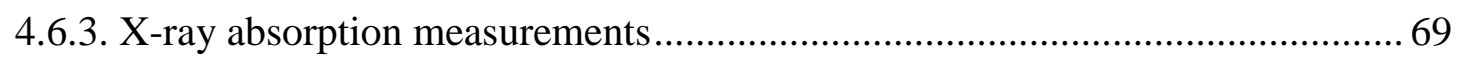

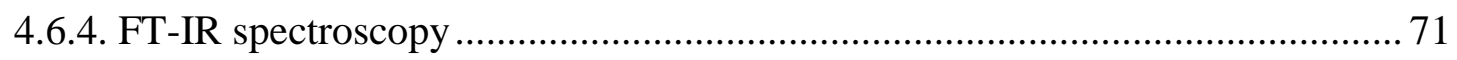

4.6.5. Testing the superoxide dismutase activity ...................................................... 76

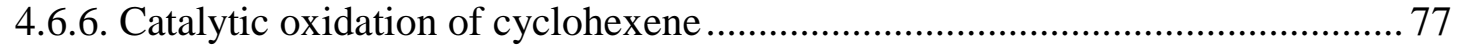

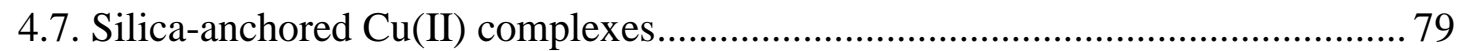

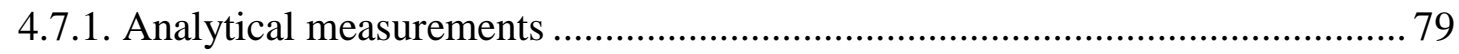

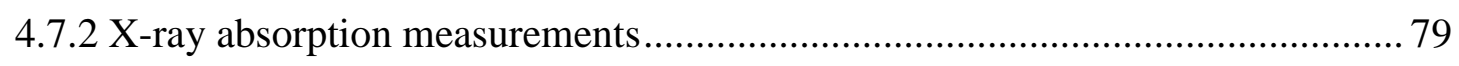

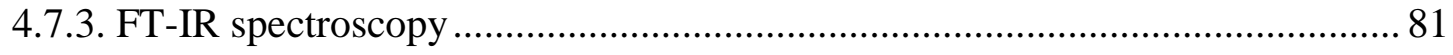

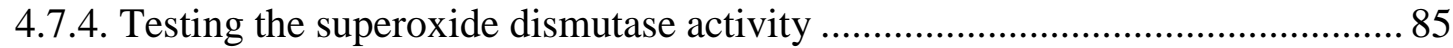

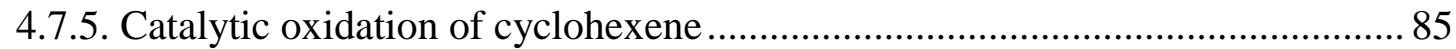

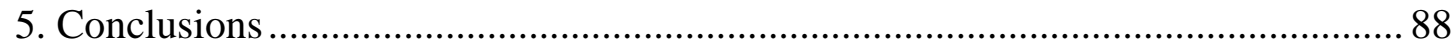

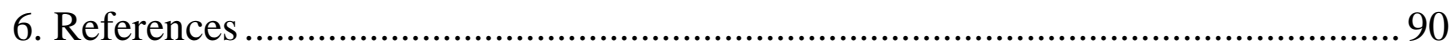




\section{Introduction and the aims of the work}

It is a general aim of modern catalysis to develop products that are able to act as highly active and, more importantly, highly selective catalysts throughout the field of chemical synthesis. In order to achieve this goal, various approaches are possible. One of the most promising ways is mimicking nature's most efficient catalysts, the enzymes. Even though living organisms contain several thousand enzymes for basically all conceivable chemical reactions, simply applying them in the synthesis of, e.g., commodity or specialty chemicals has obstacles: they are very sensitive to the environment; they work in narrow temperature and pressure ranges and in psychological aqueous solution. These shortcomings may be eliminated if a functional mimic of the active site of the enzyme is immobilised over various supports. Redox-active transition metals can be used as centre ions, while amino acids or other molecules containing groups that are able to coordinate, as ligands. Immobilising these substances on various supports facilitates the recovery and reusability of the catalyst.

In order to obtain highly active and selective biomimetic catalysts to be used in the synthesis of fine chemicals, I have constructed immobilised $\mathrm{Mn}$ (II)-, Fe(III)-, $\mathrm{Co}(\mathrm{II})-, \mathrm{Ni}(\mathrm{II})-$ and $\mathrm{Cu}(\mathrm{II})-\mathrm{C}-$ protected amino acid complexes on chloropropylated silica gel through covalent grafting. The active sites of the various types of the superoxide dismutase enzyme served as structural or functional models for the complexes. The structural features of the surface complexes were elucidated by various instrumental methods and their redox activities were probed by a biochemical test reaction. Then, many of these substances were tested as catalysts in the oxidation of cyclohexene. Cyclohexene is suitable model substrate for oxidation reactions since it has $\mathrm{C}=\mathrm{C}$ and $\mathrm{C}-\mathrm{H}$ bonds as well. The formation of the allylic oxidation products 2 cyclohexene-1-ol and 2-cyclohexene-1-one indicates the favoured attack of the activated $\mathrm{C}-\mathrm{H}$ bond, while if cyclohexene oxide is the main product epoxidation is the primary reaction on the $\mathrm{C}=\mathrm{C}$ bond.

Results of this work are presented and discussed in the dissertation. 


\section{Literature background}

\subsection{Enzymes}

Enzymes are large protein molecules with three-dimensional structure that are efficient catalysts in biochemical reactions. They increase the rate of the reaction by providing an alternative reaction pathway with lowering the energy of the transition state; thus decreasing the activation energy. Most enzyme catalysed reactions occur $10^{3}$ to $10^{8}$ times faster than the uncatalysed ones. The enzymes, just like any other catalyst, only accelerate the reaction, do not alter the equilibrium of the reaction, and they regain their original state by the end of the reaction they catalyse $[1,2]$.

Enzymes have a special region called the active site. The active site is the location where the substrates bind and the catalytic transformations take place. Lock and key hypothesis, presented by Emil Fischer in 1894 [3], is the simplest model to show how the enzymes work. The active site has a complementary shape to the substrate; they are in a relationship of a lock and a key. Daniel Koshland, in 1958 [4], suggested that the active site was flexible and altered its conformation to fit the substrate molecule. The substrate is bound to it, forming an enzyme-substrate complex, then this complex is converted to enzyme-product complex, which dissociates to the enzyme and the $\operatorname{product}(\mathrm{s})$.

Enzymes are very specific, they interact with one or just few substrates to produce products and catalyse only one particular reaction. They are working in physiological environment and can be denatured in a variety of ways resulting in the loss of their catalytic activity. Some enzymes contain a non-protein compound called cofactor, which is required for the catalysis. Cofactors are inorganic or organic compounds. Organic groups can be either prosthetic groups, which are tightly and permanently bound or coenzymes, which are loosely and temporarily bound to the enzyme molecule.

Metalloenzymes contain metal complexes in their active sites, where the transition metal is responsible for their catalytic activity. The metal ion is bound by amino acids from the protein scaffold $[1,2]$.

The International Union of Biochemistry and Molecular Biology has classified the enzymes by the kind of the catalysed chemical reactions in the following six categories (where EC number stands for Enzyme Commission number):

EC 1 Oxidoreductases: catalyse oxidation and reduction reactions 
EC 2 Transferases: catalyse functional group transfer reactions

EC 3 Hydrolases: catalyse the hydrolysis of the substrate

EC 4 Lyases: cleave $\mathrm{C}-\mathrm{C}, \mathrm{C}-\mathrm{O}, \mathrm{C}-\mathrm{N}$ and $\mathrm{P}-\mathrm{O}$ bonds by means other than oxidation and hydrolysis

EC 5 Isomerases: catalyse isomerisation reactions

EC 6 Ligases: join two molecules by the formation of new bonds [5].

\subsubsection{Superoxide dismutase (SOD) enzymes}

Superoxide dismutase enzymes protect cells from the attack of superoxide radical anions $\left(\mathrm{O}_{2}{ }^{-}\right)$. These radical species are generated in small quantities during $\mathrm{O}_{2}$ metabolism and responsible for inflammation, neuronal degeneration, diabetes, cancer and ageing. Nature has evolved several different SOD enzymes that convert these reactive species to oxygen and hydrogen peroxide through a dismutation reaction (1) [6, 7].

$$
2 \mathrm{O}_{2}{ }^{--}+2 \mathrm{H}^{+} \rightarrow \mathrm{O}_{2}+\mathrm{H}_{2} \mathrm{O}_{2}
$$

Based on the metal cofactors in the active site of SOD enzymes four classes (Cu,ZnSOD [8], FeSOD [9], MnSOD [10] and NiSOD [11]) can be distinguished.

$\mathrm{Cu}, \mathrm{ZnSOD}$ is found in all eukaryotic species and in several bacteria. The structural arrangements of the enzymes are different. In prokaryotes, there are monomeric [12], dimeric forms [13] and equilibria between monomeric and dimeric forms [14]. In eukaryotes the enzyme is homo-dimeric, with one $\mathrm{Cu}$ (II) and one $\mathrm{Zn}$ (II) ion per monomer and a molecular weight of $32 \mathrm{kDa}$ [15]. The geometry around the $\mathrm{Cu}(\mathrm{II})$ ion, i.e., in the oxidised form, is distorted; it is between square planar and square pyramidal, the metal ion is coordinated to four histidine imidazoles and the fifth

position is filled by a weakly bound water molecule located at a distance of 2.5-3.0 $\AA$ from the $\mathrm{Cu}$ (II) ion. The geometric arrangement around the $\mathrm{Zn}$ (II) ion is close to tetrahedral with three His and one aspartate ligands. One of the three His ligands is bound to both the $\mathrm{Cu}(\mathrm{II})$ and the $\mathrm{Zn}(\mathrm{II})$ ions through its two imidazole nitrogen $[15,16]$ (Figure 1). 


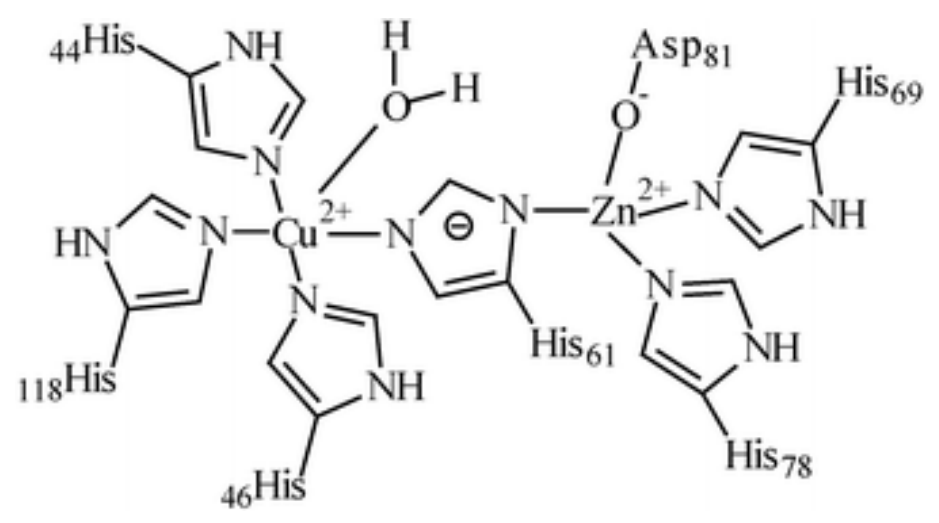

Figure 1 The active centre of the $\mathrm{Cu}, \mathrm{ZnSOD}$ enzyme.

The dismutation is a two-step reaction involving the reduction of $\mathrm{Cu}$ (II) and the oxidation of $\mathrm{Cu}(\mathrm{I})$. The first superoxide radical anion binds with one $\mathrm{O}$ to the $\mathrm{Cu}(\mathrm{II})$ centre, displacing the axial water molecule and is hydrogen bonded with the second $\mathrm{O}$ to an Arg molecule. $\mathrm{Cu}$ (II) oxidises the anion to $\mathrm{O}_{2}$, the reduced $\mathrm{Cu}(\mathrm{I})$ centre binds only three His residues, the bridging His is protonated and coordinated only to the $\mathrm{Zn}$ (II)ion, which becomes tetrahedral. The second superoxide radical anion binds to the coordinatively unsaturated $\mathrm{Cu}(\mathrm{I})$ ion; then, it positions one $\mathrm{O}$ through hydrogen bonding to the protonated His-61. Electron transfer coupled with proton transfer, the reformation of the imidazolate bridge, and the addition of a second proton from a water molecule gives $\mathrm{H}_{2} \mathrm{O}_{2}$. The $\mathrm{Zn}$ (II) ion does not play a direct role in the catalysis, it only supports the fast protonation of the $\mathrm{N} \tau$ nitrogen of His61 disconnected from the copper ion upon reduction $[8,17,18]$.

The FeSOD enzyme is present predominantly in bacteria and the chloroplast of plants, the MnSOD enzyme is found in many bacteria and mitochondria of higher organisms. The Fe- and the MnSOD enzymes are homologous both in their structure and amino acid sequence and considered to form a single class of SOD enzymes [19]. They are dimers or tetramers with one $\mathrm{Mn}$ or Fe ion per monomer unit and with a molecular weight of $22 \mathrm{kDa}$. The geometry around the metal ion is trigonal bipyramidal, coordinated by two histidine and one aspartate ligands in the equatorial plane and a histidine and a solvent molecule in the axial plane (Figure 2). The solvent molecule, that is $\mathrm{OH}^{-}$in the oxidised and $\mathrm{H}_{2} \mathrm{O}$ in the reduced form of the enzyme, is supported by an extensive network of H-bonds [20, 21]. 


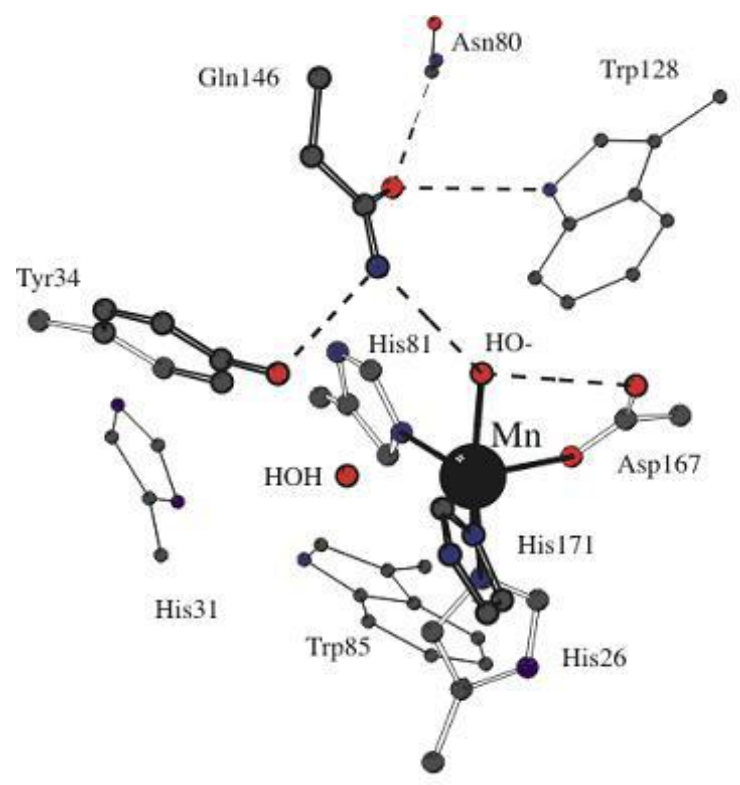

Figure 2 The active centre of MnSOD enzyme.

The major difference in the mechanism of the Fe- and MnSOD enzymes relative to the $\mathrm{Cu}, \mathrm{ZnSOD}$ enzyme is that in the formers the superoxide radical anion does not displace the solvent molecule but binds to the metal ion, increasing its coordination number. The two-step reaction mechanism is described as follows $(2,3)$ :

$$
\begin{aligned}
& \mathrm{SOD}\left(\mathrm{M}^{3+}-\mathrm{OH}^{-}\right)+\mathrm{O}_{2}^{\cdot-}+\mathrm{H}^{+} \rightarrow \mathrm{SOD}\left(\mathrm{Fe}^{2+}-\mathrm{OH}_{2}\right)+\mathrm{O}_{2} \\
& \mathrm{SOD}\left(\mathrm{Fe}^{2+}-\mathrm{OH}_{2}\right)+\mathrm{O}_{2}^{\cdot-}+\mathrm{H}^{+} \rightarrow \mathrm{SOD}\left(\mathrm{Fe}^{3+}-\mathrm{OH}^{-}\right)+\mathrm{H}_{2} \mathrm{O}_{2}
\end{aligned}
$$

where M stands for Fe or Mn [22, 23].

$\mathrm{Ni}$-containing SOD enzymes were first discovered in Streptomyces species [11] and in cyanobacteria [24]. This enzyme exists as a homohexamer consisting of fourhelix-bundle subunits. During catalysis, the oxidation state of the metallic centre cycles between $2+$ and $3+$. In the reduced state $\mathrm{Ni}(\mathrm{II})$ has square planar geometry coordinated by two thiolate groups of Cys 2 and Cys6, the deprotonated amide nitrogen of Cys2 and the amino nitrogen of His1 (Figure 3). In the oxidised form, $\mathrm{Ni}$ (III) is found in a squarepyramidal coordination environment with the axial binding of the imidazole nitrogen of His1 [25-27]. 


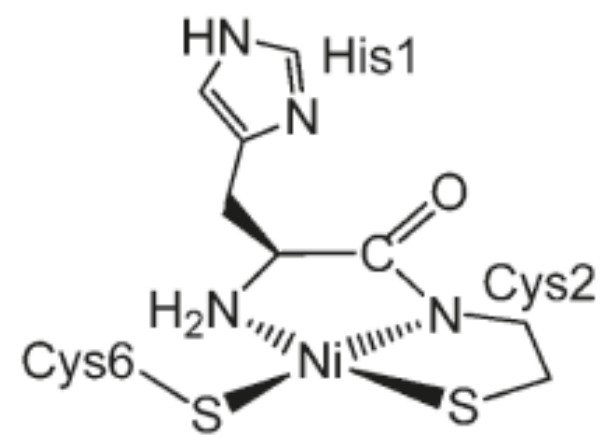

Figure 3 The active centre of NiSOD enzyme.

\subsection{SOD mimicking complexes}

Many homogeneous SOD mimicking complexes displaying appreciable SOD activities have been reviewed previously [28]. Several types of non-macrocyclic and macrocyclic polydentate molecules can be applied as ligands [29]. Fe(III) complexes with porphyrin and other polidentate ligands were synthesised. The porphyrin complex catalysed more efficiently the dismutation of the superoxide radical anions [30]. Fe(III) salen-type complexes were prepared and tested for their SOD-like activity. The SOD activity of the complexes differed depending on the applied ligands [31]. Fe(III) and $\mathrm{Mn}$ (II) complexes with an acyclic, rigid pentadentate ligand catalysed the fast disproportionation of superoxide [32]. MnSOD enzyme mimics have also been reviewed recently. Usually porphyrins, pyrroloquinoline quinones, salens and nitroxides were used as ligands. In general porphyrin based mimics were the best catalysts, while nitroxides were weak SOD mimics [33]. Imidazolate-bridged $\mathrm{Cu}$ (II)-Zn(II) complex with three multidentate ligands showed higher SOD activity than the $\mathrm{Cu}$ (II) complex from which it was built up, although it was about two magnitude lower than the native $\mathrm{Cu}, \mathrm{ZnSOD}$ enzyme [34]. The SOD activity of $1: 1$ and $1: 2 \mathrm{Cu}$ (II) complexes of curcumin were examined. The 1:1 complex was ten times more active than the 1:2 complex, since the former had distorted orthorhombic geometry, which could easily undergo geometry changes during its reaction with superoxide radical anion, while the latter was square planar and this rigid structure made the reaction unfavourable [35]. Several $\mathrm{Cu}$ (II) complexes with different carboxylate containing ligands were prepared and their SOD activities were determined. Some of the ligands contained nitrogen donor groups as well. All the complexes exhibited high SOD activity, and were only one 
magnitude lower than that of the native Cu,ZnSOD enzyme [36]. Several tetra-, pentaand hexacoordinate $\mathrm{Cu}(\mathrm{II})$ complexes with $\mathrm{N}_{3}$ donor isoindoline-based ligands were synthesised and their SOD activities were determined. The SOD activity depended on the structure and redox behaviour of the complexes [37]. The SOD activity of macrocyclic Ni(II) complexes showed that the complexes are potent NiSOD enzyme mimics [38]. Imidazolate-bridged $\mathrm{Cu}-\mathrm{Cu}, \mathrm{Cu}-\mathrm{Zn}$ and $\mathrm{Cu}-\mathrm{Ni}$ complexes showed very similar SOD activities when the same ligands were applied. The activities depended on the ligands used. In general complexes with macrocyclic ligands were more active than complexes with open chain ligands. Strong ligand field causes loss of SOD activity [39]. The superoxide radical scavenging activities of various metallobacitracin complexes were found to decrease in the order of $\mathrm{Mn}$ (II) $>\mathrm{Cu}$ (II) $>\mathrm{Co}$ (II) $>\mathrm{Ni}$ (II) [40]. $\mathrm{Mn}(\mathrm{II}), \mathrm{Fe}(\mathrm{III}), \mathrm{Co}(\mathrm{II}), \mathrm{Ni}(\mathrm{II})$ and $\mathrm{Cu}(\mathrm{II})$ complexes with $\mathrm{N}_{3}$ or $\mathrm{N}_{3} \mathrm{O}$ donor ligands were prepared. $\mathrm{Mn}(\mathrm{II}), \mathrm{Fe}(\mathrm{III})$ and $\mathrm{Cu}(\mathrm{II})$ complexes showed the highest SOD-like activities, while $\mathrm{Ni}$ (II) complexes have no appreciable activities.

\subsection{Bioinspired heterogeneous catalysis}

Enzymes catalyse a wide-range of chemical transformations. They often provide high regio- and stereoselectivity and operate under physiological conditions. Enzymecatalysed reactions can be alternatives to traditional organic syntheses under benign environmental conditions [41]. Under non-physiological environments, such as extreme temperature, $\mathrm{pH}$, non-aqueous solvents, enzymes are unstable and are easily inactivated. Therefore, they have several limitations for broader applications. Moreover, the recovery and the reuse of enzymes are also cumbersome. These drawbacks can be eliminated and more stable and reusable catalysts may be produced by immobilising the enzyme over various supports by employing methods that preserve the catalytic activity and selectivity of the support-free enzyme [42, 43].

Active and selective solid catalysts can be also fabricated by immobilising the active site or a structural or functional model of the active site of enzymes [44]. Both approaches are pursued in the world and promising results emerge. In these biomimetic catalysts, the centre ions are redox-active transition metal ions [45] and the ligands are amino acids [46] or other molecules, that are capable of coordination [47]. The immobilised complexes are often called bioinspired catalysts and their activities and 
selectivities may resemble to those of the enzymes. These substances are capable of working under more rigorous conditions and they can easily be recovered and recycled [48].

The potential advantages of immobilisation are:

- higher temperature and $\mathrm{pH}$ stabilities,

- increased activity in non-aqueous solvents,

- long-term stability,

- higher resistance to contamination,

- ease of separation from the reaction mixture,

- easy recycling.

The main disadvantages of immobilisation are:

- reduction in activity under physiological conditions,

- developing suitable methods can be expensive,

- diffusional limitation $[49,50]$.

\subsubsection{Types of immobilisation}

The main techniques for immobilisation are:

- adsorption,

- $\quad$ ionic interaction,

- covalent bonding,

- entrapment,

- $\quad$ crosslinking (in the case of enzymes) [51].

Adsorption, including hydrogen bonding, hydrophobic and van der Waals interactions, is a simple way to immobilise the catalysts. These bindings are usually too weak and leaching may also occur. The advantage of this method is its reversibility, i.e., the support can readily be regenerated and reused [52, 53].

Some literature examples are described in the followings.

Catalase was adsorbed onto a poly(2-hydroxyethylmethacrylate)-histidine membrane. The catalytic activity was smaller but the optimum temperature range was broader than that of the free enzyme. The enzyme could be readily adsorbed and desorbed, indicating the reusability of the membrane [54]. 
Biomimetic $\mathrm{Cu}(\mathrm{II})$ complexes were adsorbed on poly(4-vinylpyridine) and were used for the catalytic oxidation of phenol. The best conversion was $56 \%$ when the initial $\mathrm{Cu}$ (II) ion content was $200 \mathrm{mg} \mathrm{L}^{-1}$, and leaching was no more than $5 \mathrm{mg} \mathrm{L}^{-1}$ [55]. A binuclear carboxylate-bridged $\mathrm{Mn}(\mathrm{II}) \mathrm{Mn}(\mathrm{III})$ complex was anchored on silica by adsorption. The catalyst performed well in the epoxidation of alkenes, and could be recycled five times without significant loss in the catalytic activity [56].

Superoxide dismutase enzyme mimicking $\mathrm{Cu}(\mathrm{II})$ and $\mathrm{Cu}(\mathrm{II})-\mathrm{Zn}(\mathrm{II})$ complexes were immobilised on silica gel by adsorption. The immobilisation by hydrogen bonds increased the SOD activity of the complexes relative to the free forms [57].

Ionic bonding is a simple and reversible method to immobilise enzymes and biomimetic complexes. Nevertheless, it can be difficult to find the optimum conditions, where the substances are fully active and leaching is negligible, since this type of immobilisation depends on the $\mathrm{pH}$ and the ionic strength of the reaction mixture. Ionexchangers or other carriers that can be functionalised with a variety of positively or negatively charged groups can act as supports [58, 59].

Enzymes can exist in neutral, positively or negatively charged state depending on the $\mathrm{pH}$ of the solution. Candida antarctica lipase B was immobilised on an anionexchanger polyethylene imine. The activity of the enzyme varied upon changing the temperature and $\mathrm{pH}$ of the grafting [60]. Cation-exchanger resins could be used for the immobilisation of several positively charged enzymes and after inactivation the enzyme fully desorbed and the support could be reused [61]. Silica surfaces can be modified, for instance, with carboxylate groups to bind positively charged enzymes (organophosphorus hydrolase) or, for example, with quaternary ammonium groups to bind negatively charged enzymes (glucose oxidase) [62, 63].

Zeolites are cation-exchangers that can incorporate either the metal ions, then the complexes can be constructed inside the support [64] or the prepared biomimetic metal complexes with strong ionic interactions [65]. Zeolites have porous structure resulting in shape-selective reactions. $\mathrm{Cr}(\mathrm{III}), \mathrm{Mn}(\mathrm{II}), \mathrm{Fe}(\mathrm{III}), \mathrm{Co}(\mathrm{II}), \mathrm{Ni}(\mathrm{II})$ and $\mathrm{Cu}(\mathrm{II})$ ions were successfully exchanged into $\mathrm{NaY}$ zeolites, and were used as catalysts in the oxidation of alkenes. The results showed that the conversion and the selectivity of the reactions differed widely. The Mn-NaY had the highest reactivity and selectivity to ethers [66].

Cationic $\mathrm{Cu}$-histidine complexes were exchanged into $\mathrm{NaY}$ zeolite. The amount of the exchanged complex depended on the $\mathrm{pH}$ of the solution. The coordination sphere 
of $\mathrm{Cu}(\mathrm{II})$ changed in the cages of the zeolite, and an oxygen atom of the framework replaced one of the ligands [67].

Fe(III)-Schiff base complexes have been immobilised in zeolite Y. The compound oxidised cyclooctane with $90 \%$ conversion and were cyclooctanone selective (85\%) in the presence of $\mathrm{H}_{2} \mathrm{O}_{2}$. No metal leaching was observed during the reaction [68].

Other cation-exchanger compounds, such as montmorillonites can be used as supports. A SOD enzyme mimicking imidazolate-bridged $\mathrm{Cu}-\mathrm{Zn}$ complex was immobilised through electrostatic forces in montmorillonite. The SOD activity of the complex after immobilisation was only slightly reduced relative to the free enzyme [69].

Layered double hydroxides (LDHs) are anion-exchanger inorganic materials. Metal complexes can be intercalated directly or indirectly between the hydrotalcite layers. Pre-formed anionic $[\mathrm{Cu} \text { (nitrilotriacetate) }]^{-}$and $[\mathrm{Ni} \text { (nitrilotriacetate) }]^{-}$was intercalated into $\mathrm{ZnCr}-\mathrm{LDH}$ by the direct method, while during the indirect method, the anionic ligand was intercalated first; then, the metal complex was formed [70].

Anionic Fe(III) porphyrins were intercalated into ZnAl-LDHs and were used for alkene oxidations as catalysts. In some cases the catalytic activity of the heterogenised form was higher than that of the homogeneous one, but the opposite effect was also observed [71].

$\mathrm{Cu}$ (II) complexes were immobilised in $\mathrm{ZnAl}-\mathrm{LDH}$ as well. The materials catalysed the peroxidative oxidation of alkanes and were reused at least five times without any changes in the catalytic activities. The conversions obtained were comparable to those of the homogeneous catalysts, while the selectivity values were higher [72].

Bioinspired imidazolate-bridged $\mathrm{Cu}-\mathrm{Zn}$ complex was grafted on different types of silica by ionic interactions to mimic the structure and functionalities of the $\mathrm{Cu}, \mathrm{ZnSOD}$ enzyme. The bare complex displays lower superoxide disproportionation activity than the anchored ones. The mesostructured silica was considered to be the mimic of the proteomic skeleton [73].

Covalent binding is a strong, primary bond between the enzyme or the metal complex and the support; therefore, the catalysts do not suffer from leaching during the catalytic reactions. The main disadvantages of this type of anchoring are that the support is usually unusable after the deactivation of the catalyst resulting in additional costs and the enzyme conformation may change upon anchoring, leading to decrease in 
enzyme activity. Nevertheless, this is the most widely used method for immobilisation. Mostly polymers and silicates are used as supports, since choosing suitable reagents, reactive functional groups can be easily created on their surface [74-76].

Eupergit ${ }^{\circledR} \mathrm{C}$ is an acrylic resin which has oxirane functional groups that can react with the free amino groups of the enzymes to form stable covalent bond between $\mathrm{pH} 1$ and 12. Catalase was covalently immobilised on this carrier, and the resulting material displayed higher thermal and long-term stabilities than the free enzyme, and remarkably good reusability [77].

Horse liver alcohol dehydrogenase and ketoreductase were immobilised on functionalised silica particles. Due to conformational changes the specific activities of the anchored enzymes decreased by $60-70 \%$. The immobilised alcohol dehydrogenase showed different stereoselectivity relative the free form, while the attached ketoreductase preserved that of the support-free one.

The MnSOD enzyme was covalently grafted onto modified supermagnetic nanoparticles. The immobilisation increased the reusability and the resistance of the enzyme to $\mathrm{pH}$, temperature, enzyme inhibitors and detergents [78].

The application of polymer-bound metal complexes in organic transformations is of great interest. $\mathrm{Cu}$ (II)-valine complex was built on crosslinked poly(styrene-divinyl benzene) co-polymer. In the first step, the amino acid was immobilised, then the metal complex was formed. The compound catalysed the oxidation of alcohols and alkenes and could be recycled several times without noticeable loss in selectivity [79].

Polymeric support was covalently functionalised with tetradentate Schiff base ligand, and then, $\mathrm{Cu}(\mathrm{II}), \mathrm{Co}(\mathrm{II})$ or $\mathrm{Ni}(\mathrm{II})$ ions were complexed to them. They were used in the catalytic oxidation of various alkenes, alkanes, alcohols and thioethers with higher yield and selectivity than the neat complexes, and they were stable and could be reused more than five times without any loss in their activities [80].

$\mathrm{Cu}(\mathrm{II})$-histidine complexes were covalently grafted onto a chlorinated polystyrene resin as $\mathrm{Cu}, \mathrm{ZnSOD}$ enzyme mimics. The superoxide dismutase activities of the substances were tested. Samples having protected amino acids as ligand displayed outstanding SOD activities [81].

The various forms of silica have silanol groups on their surface that can be functionalised, and then used for immobilising transition metal-containing catalysts [82]. Schiff base ligands were anchored onto silica surface via covalent bonds, then were reacted with $\mathrm{Mn}(\mathrm{II})$ ions to form the corresponding metal complexes. Both the 
neat and the heterogenised complexes were applied in the catalytic epoxidation of alkanes. In most cases the yields were similar [83].

$\mathrm{Cu}$ (II) biomimetic complexes were grafted onto silica surface and were used for catalysing the oxidation of 3,5-ditert-butylcatechol. In the immobilised systems higher reactivity was observed than in the homogenous ones [84].

A short peptide, with His-Glu-Glu-Glu motif was immobilised on silica carrier via solid-phase peptide synthesis, and their $\mathrm{Cu}(\mathrm{II})$ and $\mathrm{Fe}(\mathrm{III})$ complexes were constructed via self-assembly. The catalysts displayed excellent catalytic activities in the oxidation of cyclohexane, and there was no metal leaching [85].

Transition metal-salicylaldimine complexes were synthesised on mesoporous silica nanoparticles (MSNs) with covalent grafting. In styrene oxidation the catalysts were highly active ( $\sim 99 \%$ conversions), Cu-MSN was the most epoxide selective ( $80 \%)$, while $\mathrm{Mn}-$ and Co-MSN had moderate epoxide selectivities ( 65\%). The catalysts maintained their activities after reuse [86].

2-acetylpyridine was directly anchored to aminopropyl silica gel, then it was coordinated to $\mathrm{Ni}(\mathrm{II})$ ions. The prepared catalyst was applied in the synthesis of dihydropyrimidinones under solvent-free conditions using microwave irradiation. Few minutes were enough for the reaction to occur, and the catalyst could be reused [87].

Another possibility of immobilisation is the entrapment of an enzyme or biomimetic complex in a polymer network such as an organic polymer or in an inorganic matrix such as silica prepared by the sol-gel method. The advantage of this method is that the catalyst is protected from the direct contact with the environment, but additional covalent attachment is often required to prevent leaching [88].

The immobilisation of lipase by entrapment in sol-gel materials increased the enzyme activity in organic solvents. The encapsulated lipases are good catalysts in the kinetic resolution of chiral alcohols and amines. The heterogenised substances could be recycled with maintaining their enantioselectivities [89].

The Cu,ZnSOD enzyme was successfully encapsulated in amphiphilic copolymer nanovesicles. The structural and functional integrities of the enzyme did not change upon entrapment, the enzyme remained active, could disproportionate the superoxide radicals and was protected from proteolytic attack [90].

Ship-in-bottle synthesis is another method for trapping biomimetic molecules inside the pores of the host. The preformed complex can be used as template during the synthesis of the carrier [91]. 
Transition metal-Schiff base complexes were immobilised by the sol-gel method in silica aero- and xerogels. The aerogel entrapped cobalt(salen) complex catalysed the oxidation of ethylbenzene to acetophenone with good selectivity. Leaching of cobalt ions was less than $0.1 \%$ [92].

Crosslinking of enzymes is a method for immobilising support-free enzyme, where the enzyme acts as support. Enzymes can be crosslinked intermolecularly or crosslinkers, such as bifunctional agents (glutaraldehyde), can be used to bind enzymes to each other. This way the advantages and disadvantages associated with the carriers are eliminated [93].

Intermolecularly crosslinked superoxide dismutase, haemoglobin and catalase were prepared and used efficiently in scavenging oxygen-derived free radicals [94].

Putting all these pieces of information together, one can conclude, that secondary bonds are relatively weak, thus, the immobilised catalyst may not survive harsher conditions. Primary bonds are stronger, and promise catalysts with higher stabilities. The ranges of the optimum conditions for ionic interactions are relatively narrow making the synthesis more difficult. Covalent grafting offers the greatest control of immobilisation and the most resistant catalysts to extreme conditions. These advantages compensate the possible loss in the catalytic activity.

\subsection{Oxidation of cyclohexene}

Catalytic epoxidation of alkenes by various oxidants is of interest since epoxides are intermediates and precursors to many useful chemical products [95], such as food additives, agrochemicals, drugs, [96] perfumes and sweeteners [97]. Cyclohexene oxide is used in the synthesis of many products, e.g., chiral pharmaceuticals, epoxy paints, pesticides, dyestuffs and rubber promoters [98].

Mainly hydrogen peroxide, organic peroxides (tert-butyl hydroperoxide), peracids (peracetic acid, $m$-chloroperbenzoic acid) and molecular oxygen are used as oxidants for oxidation of alkenes [99].

$\mathrm{H}_{2} \mathrm{O}_{2}$ is an attractive primary oxidant for liquid-phase reactions, since it is relatively cheap, readily available and useful for the synthesis of fine chemicals [100].

tert-Butyl hydroperoxide (TBHP) is also a suitable oxygen source, since it can be easily activated by transition metal complexes, has good thermal stability and is soluble 
in non-polar solvents [101]. Peracids can epoxidise alkenes without adding catalyst; however, for the uncatalysed reaction relatively high reaction temperatures and long reaction times are needed [102]. These drawbacks can be eliminated by adding transition metal catalyst to the reaction [103]. Molecular oxygen is the cheapest, the most environmentally benign and readily available oxidant, many researchers try to activate it with biomimetic catalysts [104].

The catalytic oxidation of cyclohexene takes place according to the following equation (4); the main products are shown [105]:

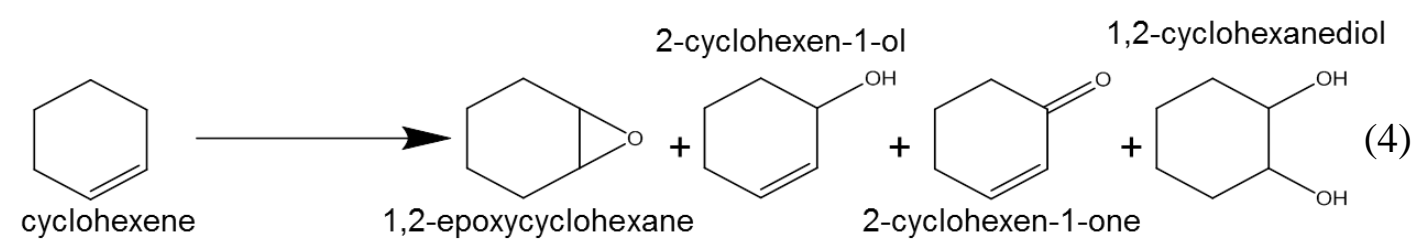

A Mn(II) complex with imidazole containing bioinspired ligands were covalently anchored on functionalised silica surface. The surface-grafted and the neat biomimetic material were tested as catalyst for cyclohexene epoxidation using $\mathrm{H}_{2} \mathrm{O}_{2}$ as oxidant, in an acetone/methanol solvent mixture, at $22{ }^{\circ} \mathrm{C}$ for $24 \mathrm{~h}$. Ammonium acetate was used as cocatalyst. The ratio of oxidant to substrate was $2: 1$. The reactions did not take place in the absence of catalyst. The supported complex was more active than the homogeneous one, the total epoxide yield was $68.7 \%$ [106]. $\mathrm{CH}_{3} \mathrm{COONH}_{4}$ is required for the efficient and epoxide-selective catalytic performance. It promoted the oxidation of $\mathrm{Mn}^{2+}$ by lowering the redox potential of the $\mathrm{Mn}(\mathrm{II}) / \mathrm{Mn}$ (III) couple and acted as a bifunctional acid-base system [107].

$\left[\mathrm{Mn}(\mathrm{II})(\mathrm{phen})_{2}\right]\left(\mathrm{CF}_{3} \mathrm{SO}_{3}\right)_{2}$ was grafted onto mesoporous SBA-15. This material could catalyse the epoxidation with peracetic acid efficiently, and it was recyclable [108].

A Mn(II)-pyrazolylpyridine complex covalently anchored onto mesoporous SBA15 was used as catalyst in the epoxidation of various alkenes with peracids. Applying acetonitrile as solvent, $0{ }^{\circ} \mathrm{C}$ reaction temperature and 30 min reaction time, more than 99\% conversion and $96 \%$ epoxide selectivity could be reached [109].

Non-heme iron(III) catalyst was synthesised on silica and used as catalyst in the oxidation of cyclohexene with $\mathrm{H}_{2} \mathrm{O}_{2}$, in $\mathrm{CH}_{3} \mathrm{CN}$ for 24 h. 2-Cyclohexen-1-ol and 2- 
cyclohexen-1-one were the main products, and the catalyst could be reused with a yield loss of $\sim 4 \%$ per use [110].

Maximum $18 \%$ conversion of cyclohexene could be reached by iron(III)-salen intercalated in $\alpha$-zirconium phosphate, in the presence of TBHP after $6 \mathrm{~h}$, when the substrate:oxidant ratio was 5. The major oxidation product was 2-cyclohexen-1-one $(75 \%)[111]$.

Nickel(II) complexes formed with macrocyclic ligands were immobilised in montmorillonite and MCM-41. The yield of cyclohexene epoxide in the presence of TBHP depended on the solvent and the support. For montmorillonite, 100\% epoxide selectivity could be reached when $\mathrm{CHCl}_{3}$ was the solvent; however, the conversion was only $8 \%$. Changing the solvent to $\mathrm{CH}_{3} \mathrm{CN}$ decreased the selectivity to $41 \%$, and increased the conversion to $32 \%$. Under the same conditions, MCM-41 usually increased the conversions and did not change the selectivity of the reaction. There was no desorption during the reaction [112].

Polymer-anchored $\mathrm{Cu}(\mathrm{II})$ Schiff base complex was prepared and its catalytic activity was tested in the oxidation of cyclohexene with TBHP at $50{ }^{\circ} \mathrm{C}$ and $7 \mathrm{~h}$ reaction time. Altering the solvent resulted in shift of the selectivities. Water $>$ tetrahydrofuran $>$ acetonitrile were selective in the formation of ketone, while dichloromethane was selective in epoxide formation. The conversions were close to each other. The catalyst could be recycled and reused several times without much loss in the catalytic activities [113].

$\left[\mathrm{Cu}(\mathrm{His})_{2}\right]^{+}$complex was exchanged into $\mathrm{Na}-\mathrm{Y}$ zeolite and the solid material catalysed the oxidation of cyclohexene with TBHP at $60{ }^{\circ} \mathrm{C}$. After $24 \mathrm{~h}$, the conversion was $28 \%$ and 1,2-cyclohexanediol was the main product. $\mathrm{Cu}$ (II)-leaching was not observed during the reaction [114].

$\mathrm{Cu}$ (II) and $\mathrm{Co}$ (II) salycilaldimine complexes were anchored on silica supports and were evaluated for the oxidation of cyclohexene with $\mathrm{H}_{2} \mathrm{O}_{2}$, in acetonitrile, at $60{ }^{\circ} \mathrm{C}$ for $27 \mathrm{~h}$. The oxidant:substrate ratio was $1: 1$. The immobilised catalyst favoured the allylic oxidation pathway, i.e., 2-cyclohexen-1-ol and 2-cyclohexen-1-one were the major products. In most cases, the $\mathrm{Co}(\mathrm{II})$ catalyst was more active and more selective in the formation of ketone than the $\mathrm{Cu}(\mathrm{II})$ catalyst [115].

Cobalt(II), nickel(II), copper(II) complexes with 1-(2-pyridylazo)-2-naphthol ligand were immobilised in zeolite Y. The resulting catalysts oxidised cyclohexene very slowly in decane, when TBHP was the oxidising agent in decane at $30{ }^{\circ} \mathrm{C}$. After $24 \mathrm{~h}$, 
maximum 35\% conversion of cyclohexene could be reached. The conversions changed on altering the metal ion in the following order: $\mathrm{Co}(\mathrm{II})>\mathrm{Cu}(\mathrm{II})>\mathrm{Ni}$ (II). In all instances, 1-tert-butyl-peroxy-2-cyclohexene was the main product, indicating the involvement of $\mathrm{tBuOO}$ radical as a reactive intermediate $[116,117]$.

Alumina-supported Mn(II)-, $\mathrm{Co}(\mathrm{II})-, \mathrm{Ni}(\mathrm{II})-$ and $\mathrm{Cu}(\mathrm{II})$-tetradentate Schiff-base ligand complexes catalysed the oxidation of cyclohexene with $\mathrm{H}_{2} \mathrm{O}_{2}$ and TBHP in various solvents, under reflux for $8 \mathrm{~h}$. The substrate to oxidant ratio was 1:1.6. On using $\mathrm{H}_{2} \mathrm{O}_{2}$, cyclohexene epoxide was the main product; thus, oxidation occurred on the double bond, when TBHP was the oxidant, the reaction was selective towards 2cyclohexene-1-one formation. It seems that these reactions proceed through different intermediates. The conversions differed widely depending on the solvents and the metal ions. They decreased in the order of dichloromethane $>$ chloroform $>$ methanol $>$ acetonitrile and $\mathrm{Mn}(\mathrm{II})>\mathrm{Co}(\mathrm{II})>\mathrm{Ni}(\mathrm{II})>\mathrm{Cu}(\mathrm{II})$. Although leaching of the metal ions did not occur during the reactions, the catalytic activity was lowered upon reuse by $\sim 2.7 \%$ [118].

In general, when $\mathrm{H}_{2} \mathrm{O}_{2}$ or TBHP was used as oxidant $24 \mathrm{~h}$ reaction time or high temperature was needed to reach reasonable conversions. The selectivities depended on the applied solvents and co-catalyst. High epoxide-selectivity resulted in the decrease of the conversion. Peracetic acid is not so often used in transition metal catalysed epoxidation of cyclohexene, since it catalyses the reaction without catalyst as well. However, applying catalyst, peracetic acid can be more reactive and can epoxidise alkenes with higher conversions, under lower reaction time. 


\section{Experimental part}

\subsection{Materials and methods of syntheses}

For the syntheses, C-protected (in the form of methyl ester) L-histidine, Ltyrosine, L-cysteine and L-cystine, and tert-butoxycarbonyl(BOC)-protected L-histidine and L-tyrosine were used as ligands. Metal ion sources were $\mathrm{MnCl}_{2} \cdot 5 \mathrm{H}_{2} \mathrm{O}, \mathrm{FeCl}_{3} \cdot 6 \mathrm{H}_{2} \mathrm{O}$, $\mathrm{CoCl}_{2} \cdot 6 \mathrm{H}_{2} \mathrm{O}, \mathrm{NiCl}_{2} \cdot 6 \mathrm{H}_{2} \mathrm{O}$ and $\mathrm{CuCl}_{2} \cdot 2 \mathrm{H}_{2} \mathrm{O}$. Chloropropylated silica gel (SG - particle size: $230-400$ mesh, BET surface area: $500 \mathrm{~m}^{2} / \mathrm{g}$, functionalisation: $8 \%$ )] was used as support. These materials as well as the 2-propanol solvent were products of Aldrich Chemical Co. All the chemicals were of analytical grade and were used without further purification.

The general features of the syntheses are as follows. The first step of immobilisation was the reaction of the appropriately protected amino acid $(1.75 \mathrm{mmol})$ and the support ( $0.5 \mathrm{~g}$, containing $0.35 \mathrm{mmol}$ of chlorine atoms). The C-protected amino acids were covalently grafted onto the support through $\mathrm{N}$-alkylation like reaction, while the $\mathrm{N}$-protected ones were with esterification reaction by refluxing the mixture in 2propanol $\left(60 \mathrm{~cm}^{3}\right)$ under basic conditions. After $24 \mathrm{~h}$, the solid substance was filtered, washed several times in order to remove the uncoupled amino acid excess and dried. Complexation followed the anchoring: the grafted support was soaked in the 2propanolic $\left(60 \mathrm{~cm}^{3}\right)$ solution of the metal salt $(1.75 \mathrm{mmol})$ under continuous stirring at room temperature for $24 \mathrm{~h}$. After filtering and washing, the obtained material was divided into two parts. Half of it was set aside. This is what we call covalent grafting under ligand-poor conditions, i.e., only the immobilised protected amino acids were available for coordination. To the other half, 2-propanolic $\left(60 \mathrm{~cm}^{3}\right)$ solution of the appropriately protected amino acid derivative was added in excess $(0.875 \mathrm{mmol})$, and the suspension was continuously stirred at room temperature for $24 \mathrm{~h}$. Then, the solid material was filtered, rinsed with 2-propanol several times and dried. Latter was named covalent grafting under ligand-excess conditions, i.e., the surface-grafted complex might have rearranged in the presence of excess amino acid mixture.

Surface-grafted complexes were prepared having both uniform and mixed amino acid derivatives (two protected amino acids were used) as ligands. Two methods were applied for the syntheses when mixed ligands were used. In method ' $A$ ', one of the protected amino acid ester was covalently anchored to the surface of the support; then, it 
was soaked in the metal salt solution, and after filtering and thorough washing the final substance was made by allowing complexation with excess amounts of the other amino acid ester. In method ' $B$ ' a 1:1 molar mixture of the protected amino acids was grafted onto the surface of the support; then, the metal complex was formed. Parts of the materials thus formed were further treated in excess 1:1 protected amino acid mixtures resulting in the formation of surface-anchored complexes under ligand-excess conditions. The other experimental parameters were the same as described above.

The synthesised materials and their code used in the followings are listed as follows:

SG-His-OMe-M

SG-His-OMe-M-H-His-OMe

SG-Tyr-OMe-M,

SG-Tyr-OMe-M-H-Tyr-OMe,

SG-Cys-OMe-M,

SG-Cys-OMe-M-H-Cys-OMe,

$\mathrm{SG}-(\mathrm{Cys}-\mathrm{OMe})_{2}-\mathrm{M}$,

SG-(Cys-OMe $)_{2}-\mathrm{M}-\mathrm{H}-(\mathrm{Cys}-\mathrm{OMe})_{2}$,

SG-His-OMe-M-H-Tyr-OMe,

SG-Tyr-OMe-M-H-His-OMe,

SG-His-OMe;Tyr-OMe-M,

SG-His-OMe;Tyr-OMe-M-H-His-OMe;H-Tyr-OMe,

SG-His-OMe-M-H-Cys-OMe,

SG-Cys-OMe-M-H-His-OMe,

SG-His-OMe;Cys-OMe-M,

SG-His-OMe;Cys-OMe-M-H-His-OMe;H-Cys-OMe,

SG-His-OMe-M-(H-Cys-OMe $)_{2}$,

SG-(Cys-OMe $)_{2}-\mathrm{M}-\mathrm{H}-\mathrm{His}-\mathrm{OMe}$,

SG-His-OMe;(Cys-OMe $)_{2}-\mathrm{M}$,

SG-His-OMe;(Cys-OMe $)_{2}-\mathrm{M}-\mathrm{H}-\mathrm{His}-\mathrm{OMe}$;(H-Cys-OMe $)_{2}$,

SG-(Boc-His-O),

SG-(Boc-Tyr-O),

where $\mathrm{M}$ means the applied metal ion, i.e., $\mathrm{Mn}(\mathrm{II}), \mathrm{Fe}(\mathrm{III}), \mathrm{Co}(\mathrm{II}), \mathrm{Ni}(\mathrm{II})$ or $\mathrm{Cu}(\mathrm{II})$. complex made under ligand-poor conditions, complex made under ligand-excess conditions, 


\subsection{Analytical measurements}

The amount of metal ions on the surface-modified silica gel was measured by an Agilent 7700x ICP-MS. Before measurements, a few milligrams of the anchored complexes measured by analytical accuracy were digested in $1 \mathrm{~cm}^{3} \mathrm{cc} . \mathrm{H}_{2} \mathrm{SO}_{4}$; then, they were diluted with distilled water to $50 \mathrm{~cm}^{3}$ and filtered.

The nitrogen content of the samples was determined by the Kjeldahl method. 5 $\mathrm{cm}^{3}$ cc. $\mathrm{H}_{2} \mathrm{SO}_{4}$ and $1 \mathrm{~cm}^{3} 30 \%$ solution of $\mathrm{H}_{2} \mathrm{O}_{2}$ were added to approximately $100 \mathrm{mg}$ of the grafted complexes weighed by analytical accuracy. $\mathrm{CuSO}_{4} \cdot 5 \mathrm{H}_{2} \mathrm{O}$ was used as catalyst to increase the boiling point of the medium. The reaction mixture was boiled for some hours, to obtain colourless mixture from the initially dark-coloured suspension. Then it was diluted with $40 \mathrm{~cm}^{3}$ distilled water and was distilled with a $20 \%$ solution of sodium hydroxide in the presence of phenolphthalein indicator. The released ammonia was absorbed in $0.1 \mathrm{M}$ solution of $\mathrm{HCl}$. Then, the remainder acid was titrated with 0.1 $\mathrm{M}$ solution of $\mathrm{NaOH}$ in the presence of methyl orange indicator.

\subsection{UV-Vis diffuse reflectance spectroscopy}

For the optical characterisation of the Ni(II)-containing samples, UV-Vis diffuse reflectance spectroscopy (UV-Vis DRS) was used. A Micropack HPX-2000 High Power Xenon Lamp was the light source and an Ocean Optics ADC1000-USB diode array photometer was applied as detector. Spectra were recorded in the range of 350-850 nm using a Micropack ISP508RGT integration sphere. Approximately $100 \mathrm{mg}$ of samples were used for each measurement and their spectra were recorded without any additional sample preparation.

Let me summarise here the expected spectral features and how they are translated to structural information.

In the electronic spectra of octahedral $\mathrm{Ni}(\mathrm{II})$ complexes three spin-allowed transitions are expected. The ${ }^{3} \mathrm{~A}_{2 \mathrm{~g}} \rightarrow{ }^{3} \mathrm{~T}_{2 \mathrm{~g}}(\mathrm{v} 1)$ transition appears at $1300-800 \mathrm{~nm}$, the ${ }^{3} \mathrm{~A}_{2 \mathrm{~g}} \rightarrow{ }^{3} \mathrm{~T}_{1 \mathrm{~g}}(\mathrm{~F})(\mathrm{v} 2)$ appears at $800-500 \mathrm{~nm}$, while the ${ }^{3} \mathrm{~A}_{2 \mathrm{~g}} \rightarrow{ }^{3} \mathrm{~T}_{1 \mathrm{~g}}(\mathrm{P})$ (v3) transition is between 400-300 nm. Tetrahedral Ni(II) complexes have bands at 1400-900 nm corresponding to ${ }^{3} \mathrm{~T}_{1} \rightarrow{ }^{3} \mathrm{~A}_{2}$ (v2) transition, at 800-550 nm due to the ${ }^{3} \mathrm{~T}_{1 \mathrm{~g}} \rightarrow{ }^{3} \mathrm{~T}_{1 \mathrm{~g}}(\mathrm{P})(\mathrm{v} 3)$ transition, and the ${ }^{3} \mathrm{~T}_{1} \rightarrow{ }^{3} \mathrm{~T}_{2}(v 1)$ transition is just occasionally observed. Square planar 
$\mathrm{Ni}$ (II) complexes show three strong absorptions in the range of $450-300 \mathrm{~nm}$ arising from the ${ }^{1} \mathrm{~A}_{1 \mathrm{~g}} \rightarrow{ }^{1} \mathrm{~A}_{2 \mathrm{~g}},{ }^{1} \mathrm{~A}_{1 \mathrm{~g}} \rightarrow{ }^{1} \mathrm{~B}_{1 \mathrm{~g}},{ }^{1} \mathrm{~A}_{1 \mathrm{~g}} \rightarrow{ }^{1} \mathrm{E}_{\mathrm{g}}$ transitions [119].

\subsection{Electron paramagnetic resonance (EPR) measurements}

EPR measurements were only used for the Mn(II)-containing samples. The spectra were recorded with a BRUKER EleXsys E500 spectrometer (microwave frequency $9.51 \mathrm{GHz}$, microwave power $12 \mathrm{~mW}$, modulation amplitude $5 \mathrm{G}$, modulation frequency $100 \mathrm{kHz}$ ) in quartz EPR tubes at room temperature. Approximately $10 \mathrm{mg}$ of samples were used for each measurement and their spectra were recorded without any additional sample preparation.

All recorded EPR spectra were simulated with a spectrum decomposition method by the EPR [120] computer program. The determined $A_{\text {iso }}$ values suggest the coordination geometry of the complexes. If $A_{\text {iso }}=80-100 \mathrm{G}$, the complexes are octahedral, in tetrahedral coordination it is $20-25 \%$ lower [121].

\subsection{X-ray absorption spectroscopy (XAS) measurements}

The major characteristics of this method are described briefly in the followings. $\mathrm{XAS}$ is the measurement of the X-ray absorption coefficient of a material as a function of energy. X-ray energies are high enough to eject one or more core electrons from an atom, via the photoelectric effect. These electrons have well-defined binding energies. The absorption coefficient decreases with the increase in energy, until it reaches the binding energy of an inner electron. This is the absorption edge of the element. At this point a sharp peak appears in the spectrum and the corresponding energy is the so-called threshold energy.

The importance of XAS derives from the fact that there is fine structure superimposed on the absorption edge. This fine structure is often divided into X-ray absorption near edge structure (XANES), for structure in the immediate vicinity of the edge and extended X-ray absorption fine structure (EXAFS), referring to structure well above the absorption edge. The various regions of the X-ray absorption spectrum provide different information. XANES gives information on the bonding character, the oxidation state and the coordination geometry of the element studied, while from the 
EXAFS region structural parameters like coordination number, bond lengths, etc. can be extracted.

The measurements were carried out on the K-edge of the metals at MAX-lab at beamline I811. This is a superconducting multipole wiggler beamline equipped with a water-cooled channel cut $\mathrm{Si}(111)$ double crystal monochromator delivering at $10 \mathrm{keV}$, approximately $2 \times 10^{15}$ photons/s/0.1\% bandwidth with horizontal and vertical FWHM of 7 and $0.3 \mathrm{mrad}$, respectively [122]. A beamsize of $0.5 \mathrm{~mm} \times 1.0 \mathrm{~mm}$ (width $\times$ height) was used. The incident beam intensity $\left(\mathrm{I}_{0}\right)$ was measured with an ionisation chamber filled with a mixture of $\mathrm{He} / \mathrm{N}_{2}$. Higher order harmonics were reduced by detuning the second monochromator to $50-70 \%$ of the maximum intensity, depending on the metal. Data collection was performed in transmission mode. $300 \mathrm{mg}$ samples were measured in Teflon spacers with Kapton tape windows. Data were treated by the Demeter program package $[123,124]$.

XAS spectra were normalised to an edge jump of unity and the removal of the background absorption was done.

The EXAFS data were $k^{3}$-weighted and Fourier transformed in the range of $k=$ 2-12 $\AA^{-1}$. The ranges for the backtransform were 1-3 $\AA$ for all complexes. The fitted parameters included the amplitude reduction factor $\left(S_{0}{ }^{2}\right)$, interatomic distances $(\mathrm{R})$, Debye-Waller factors $\left(\sigma^{2}\right)$ and energy shift $\left(\Delta \mathrm{E}_{0}\right)$. The coordination numbers $(\mathrm{N})$ were kept constant during each optimisation, but a range of coordination numbers were used to find the best fit.

The main objectives of these measurements were to determine the coordination numbers, geometries around the metal ions, and to find out whether the sulphur atom was coordinated to the central ion in the anchored $\mathrm{Mn}(\mathrm{II}), \mathrm{Fe}(\mathrm{III}), \mathrm{Co}(\mathrm{II}), \mathrm{Ni}$ (II) or $\mathrm{Cu}(\mathrm{II})$ complexes.

\subsection{FT-IR spectroscopy}

Structural information on each step of the synthesis procedure was obtained by far- and mid-range infrared spectroscopy. Mid-range spectra were recorded with a BIORAD Digilab Division FTS-65 A/896 FT-IR spectrophotometer with $4 \mathrm{~cm}^{-1}$ resolution, measuring diffuse reflectance. 256 scans were collected for each spectrum. $300 \mathrm{mg} \mathrm{KBr}$ and $10 \mathrm{mg}$ sample were combined and finely grounded. Spectra were evaluated by the 
Win-IR package. They were baseline-corrected, smoothed (if it was necessary) and the spectra of the supports were subtracted. The $3800-600 \mathrm{~cm}^{-1}$ wavenumber range was investigated. The comparison of the difference mid IR spectra of the anchored amino acid derivatives with and without metal ion, and the spectra of the pristine amino acid derivatives gives indirect information on the coordinating groups. The difference $\Delta[\Delta=$ $\left.v_{\mathrm{asym}(\mathrm{COO}-)}-v_{\mathrm{sym}(\mathrm{COO}-)}\right]$ between the asymmetric and symmetric carboxylate vibrations gives information about the coordination mode of the carboxylate group. The coordination can be either bidentate chelating $\left(\Delta_{\text {complex }}<\Delta_{\text {ligand }}\right)$ or bidentate bridging $\left(\Delta_{\text {complex }} \sim \Delta_{\text {ligand }}\right)$ or monodentate $\left(\Delta_{\text {complex }}>\Delta_{\text {ligand }}\right)$ [125]. A shift in the position of the carbonyl group and the phenolic $\mathrm{C}-\mathrm{O}$ or the absence of the $\mathrm{S}-\mathrm{H}$ stretching vibration are indicators of the participation of these groups in complexation $[126,127]$.

Far-range spectra were recorded with a BIO-RAD Digilab Division FTS-40 vacuum FT-IR spectrophotometer with $4 \mathrm{~cm}^{-1}$ resolution. 256 scans were collected for each spectrum. The Nujol mull technique was used between two polyethylene windows (the suspension of $10 \mathrm{mg}$ sample and a drop of Nujol mull). Spectra were evaluated by the Win-IR package. They were baseline-corrected and smoothed (if it was necessary). Unfortunately, in several cases the spectra could not be used for evaluation. The spectra in the far IR region provide direct information on metal ion-functional group coordination, although assignation of the vibrations in the far IR spectra is not a trivial exercise. For making it easier probe complexes having uniform, thus easily identifiable coordinating groups were prepared and their far IR spectra were registered. $\mathrm{Mn}(\mathrm{II})$, $\mathrm{Fe}(\mathrm{III}), \mathrm{Co}(\mathrm{II}), \mathrm{Ni}(\mathrm{II})$ and $\mathrm{Cu}(\mathrm{II})$ complexes of imidazole, isopropylamine and monosodium malonate were prepared. Each probe complex was synthesised via using 2-propanol $\left(10 \mathrm{~cm}^{3}\right)$ as solvent. The metal salt $\left(4 \times 10^{-4} \mathrm{~mol}\right)$ and the ligand $\left(2.4 \times 10^{-3}\right.$ mol) were stirred for $24 \mathrm{~h}$ at room temperature to get solid precipitate. The obtained materials were filtered and washed with 2-propanol.

\subsection{Testing the superoxide dismutase activity}

The SOD activity was tested by the Beauchamp-Fridovich reaction [128]. For this biochemical test reaction riboflavin, L-methionine and nitro blue tetrazolium were used. Under aerobic conditions reaction takes place on illumination between riboflavin and Lmethionine. It is a reduction and the reduced form of riboflavin reacts with oxygen 
forming a peroxide derivative. This derivative decomposes giving the superoxide radical anion. This radical ion is captured by the nitro blue tetrazolium (NBT) and its original yellow colour turns blue.

The transformation can be followed by Vis spectrophotometry, measuring the absorbance at $560 \mathrm{~nm}$. If our enzyme mimicking material works well, it successfully competes with NBT in capturing the superoxide radical ion. Thus, the photoreduction of NBT is inhibited. The SOD probe reaction was carried out at room temperature in a suspension of the immobilised complex at $\mathrm{pH}=7$ ensured with a phosphate or for the $\mathrm{Mn}(\mathrm{II}) \quad$ complexes, 4-(2-hydroxyethyl)-1-piperazineethanesulfonic acid (HEPES) buffer. The reaction mixture contained $0.1 \mathrm{~cm}^{3}$ of $0.2 \mathrm{mM}$ riboflavin, $0.1 \mathrm{~cm}^{3}$ of $5 \mathrm{mM}$ NBT, $2.8 \mathrm{~cm}^{3}$ of $50 \mathrm{mM}$ buffer, containing EDTA $(0.1 \mathrm{mM})$, L-methionine (13 $\left.\mathrm{mM}\right)$ and the catalyst. Riboflavin was added last and the reaction was initiated by illuminating the tubes with two $15 \mathrm{~W}$ fluorescent lamps. Equilibrium could be reached in 10 minutes. EDTA masks the interfering metal ion traces, since the metal ion-EDTA complexes have no SOD activity. From the resulting graph the volume of enzyme mimicking complex corresponding to $50 \%$ inhibition $\left(\mathrm{IC}_{50}\right)$ was registered to allow a comparison with the efficiency of the real enzyme and other SOD mimics. The enzyme mimic works the better when the $\mathrm{IC}_{50}$ is the smaller. There was no reaction without illumination and the support did not display SOD activity either.

\subsection{Catalytic oxidation of cyclohexene}

In the reaction a vial with septum was loaded with the catalyst $(25 \mathrm{mg})$, acetone $(10 \mathrm{ml})$, cyclohexene $(5 \mathrm{mmol})$ and 1 (for the $\mathrm{Mn}(\mathrm{II})$ complexes) or $2.5 \mathrm{mmol}$ peracetic acid ( $\sim 39 \%$ in acetic acid). After 1 (for the $\mathrm{Mn}(\mathrm{II})$ complexes) or $3 \mathrm{~h}$ continuous stirring at room temperature, the mixture was analysed quantitatively by a Hewlett-Packard 5890 Series II gas chromatograph (GC) using an Agilent HP-1 column and the internal standard technique. The temperature was increased in stages from $50{ }^{\circ} \mathrm{C}$ to $250{ }^{\circ} \mathrm{C}$. The products were identified by the authentic samples. 


\section{Results and discussion}

\subsection{Mid IR spectra of the anchored and non-anchored ligands}

From the mid IR difference spectra of the silica gel anchored C-protected amino acids (Figure 4), it is clear that covalent anchoring of the ligands were successful, since well-structured spectra were obtained after removing the contribution of the support. Comparison of these spectra with those of the C-protected amino acids (Figure 5), reveals that in all cases carboxylate vibrations appeared. It means that the $\mathrm{C}$-protecting group hydrolysed upon covalent anchoring, due to the basic conditions, and is present as carboxylate group in the samples. One must keep this fact in mind, nevertheless, the code of the materials, e.g., SG-His-OMe, was not changed, it contains the formula of the initial C-protected amino acid.

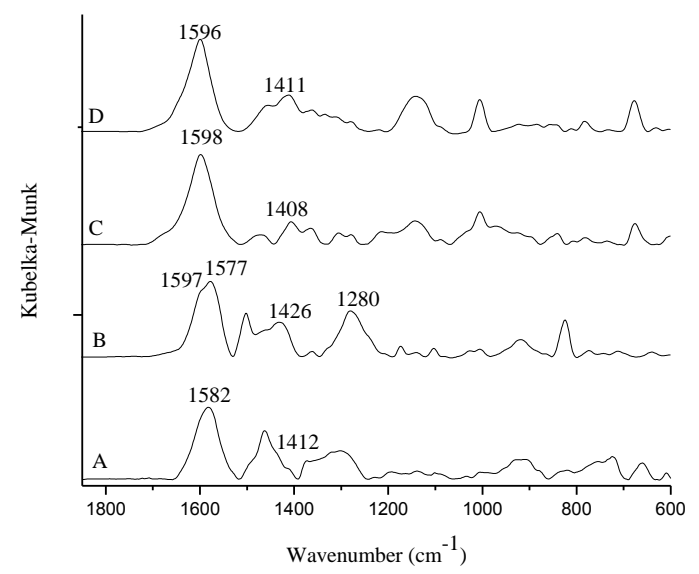

Figure 4 The IR spectra of A - SG-His-OMe, B - SG-Tyr-OMe, C - SG-Cys-OMe, $\mathrm{D}-\mathrm{SG}-(\mathrm{Cys}-\mathrm{OMe})_{2}$.

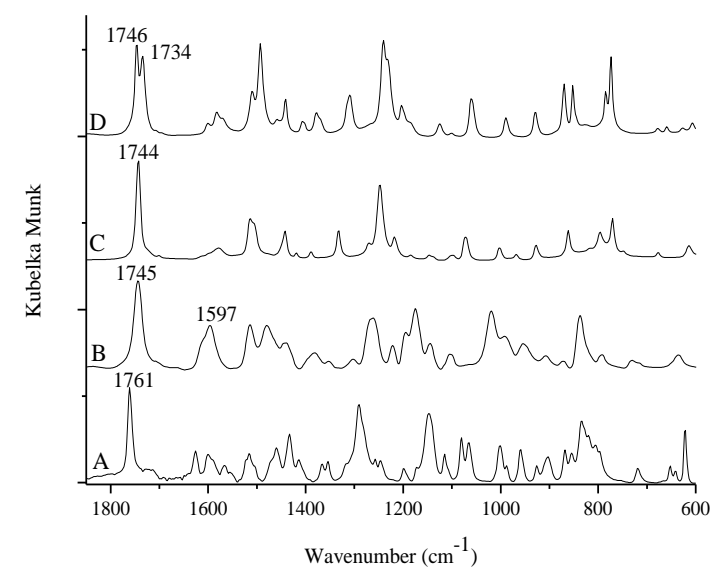

Figure 5 The IR spectra of A - H-His-OMe, B - H-Tyr-OMe, C - H-Cys-OMe, $\mathrm{D}-(\mathrm{H}-\mathrm{Cys}-\mathrm{OMe})_{2}$. 
Grafting of the N-protected amino acids was also successful (Figure 6), the BOC protecting group is stable to hydrolysis under basic conditions, for deprotection, special conditions are needed. Complexes prepared with $\mathrm{N}$-protected amino acids, mainly due to length constraints, are not discussed in the dissertation.

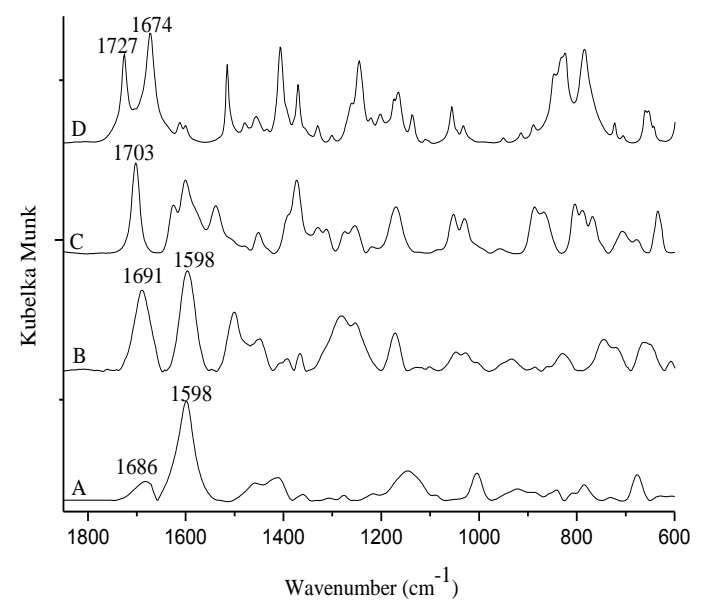

Figure 6 The IR spectra of A - SG-(Boc-His-O), B - SG-(Boc-Tyr-O), $\mathrm{C}$ - Boc-His-OH, D - Boc-Tyr-OH.

\subsection{Far IR spectra of the probe complexes}

Assignments of the metal-ligand vibrations were based on the differences between the vibration bands of the pristine ligand, the metal salt, and the complex in the low-frequency IR region. New bands appearing after metal coordination are usually attributed to metal-ligand vibrations. It was taken into account that in the spectra of the metal salts, there were two absorptions between 500 and $400 \mathrm{~cm}^{-1}$ belonging to the various vibrations of coordinated water stemming from the crystalline water of the starting salts [129].

The low-frequency IR spectrum of isopropylamine contains two main vibrations at 465 and $400 \mathrm{~cm}^{-1}$ related to the in-plane and out-of-plane $\mathrm{C}-\mathrm{C}-\mathrm{N}$ deformations, respectively [130]. In the spectra of the complexes with isopropylamine (Figure 7), two new bands appeared at $377-370 \mathrm{~cm}^{-1}$ and $275-265 \mathrm{~cm}^{-1}$. They most probably correspond to the $\mathrm{M}(\mathrm{II})-\mathrm{N}_{\text {amino }}$ bonds (M(II) stands for the metal ion applied). These observations are in good agreement with those published for $\mathrm{Cu}$ (II)-ethylenediamine complexes [131]. The bands above $400 \mathrm{~cm}^{-1}$ are attributed to the vibrations of the ligand, and may correspond to the various vibrations of coordinated water. 


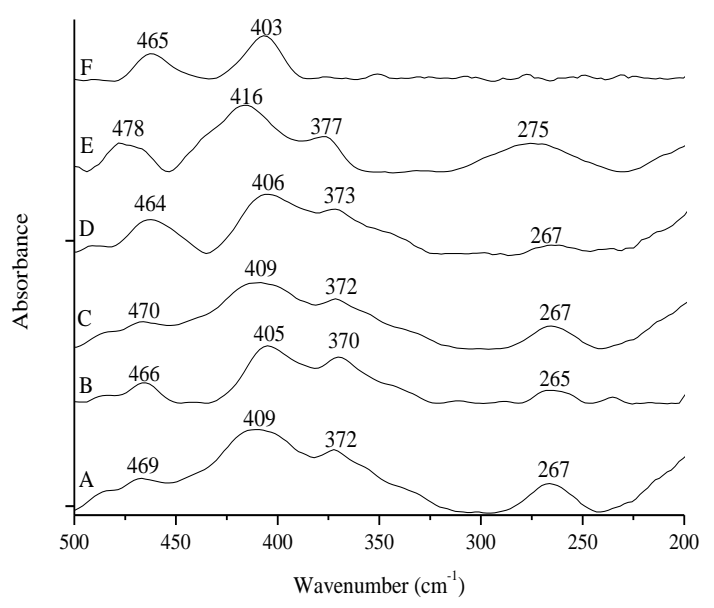

Figure 7 The far IR spectra of isopropylamine complexes with A - Mn(II), B- Fe(III), $\mathrm{C}-\mathrm{Co}(\mathrm{II}), \mathrm{D}-\mathrm{Ni}(\mathrm{II}), \mathrm{E}-\mathrm{Cu}(\mathrm{II})$ and $\mathrm{F}-$ the spectrum of isopropylamine.

The spectrum of imidazole between $500 \mathrm{~cm}^{-1}$ and $200 \mathrm{~cm}^{-1}$ is empty. However, in the spectra of the complexes, a broad band is seen (Figure 8). The band at $291-241 \mathrm{~cm}^{-1}$ belongs to the $\mathrm{M}(\mathrm{II})-\mathrm{N}_{\text {imidazole }}$ stretching mode. These spectra are pronouncedly $\mathrm{M}(\mathrm{II})$ dependent (as opposed to isopropylamine complexes). The $\mathrm{M}(\mathrm{II})-\mathrm{N}_{\text {imidazole }}$ stretching frequency increases in the order of $\mathrm{Cu}(\mathrm{II})>\mathrm{Ni}$ (II) $>\mathrm{Co}(\mathrm{II}) \sim \mathrm{Fe}(\mathrm{III}) \sim \mathrm{Mn}$ (II). Our assignments are in good agreement with literature data [132].

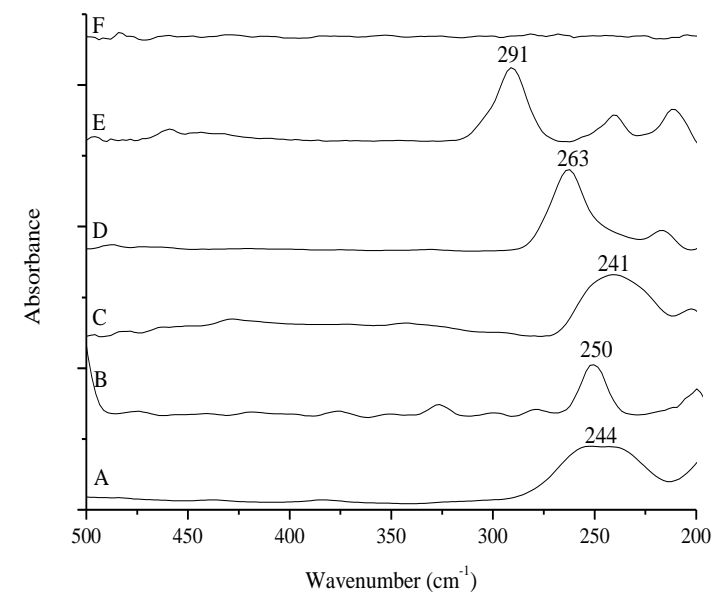

Figure 8 The far IR spectra of imidazole complexes with A - Mn(II), B- Fe(III), $\mathrm{C}-\mathrm{Co}(\mathrm{II}), \mathrm{D}-\mathrm{Ni}(\mathrm{II}), \mathrm{E}-\mathrm{Cu}(\mathrm{II})$ and $\mathrm{F}-$ the spectrum of imidazole.

There are two strong vibrations in the low-frequency IR spectrum of malonic acid. The band at $451 \mathrm{~cm}^{-1}$ corresponds to the $\mathrm{C}-\mathrm{C}-\mathrm{C}$ deformation and the peak at $429 \mathrm{~cm}^{-1}$ indicates skeletal twist [133]. In Figure 9, the spectra of the complexes are displayed. 
These spectra are also M(II)-dependent. The complexes may be divided into two groups. One group exhibits a single band at $344 \mathrm{~cm}^{-1}$, and the other group shows two bands between 370 and $300 \mathrm{~cm}^{-1}$. These bands are considered to be $\mathrm{M}(\mathrm{II})-\mathrm{O}_{\text {malonate }}$ stretching vibrations. It seems that the position of this vibration is very sensitive to the environment. The bands above $390 \mathrm{~cm}^{-1}$ may be attributed to the vibrations of the ligand and coordinated water.

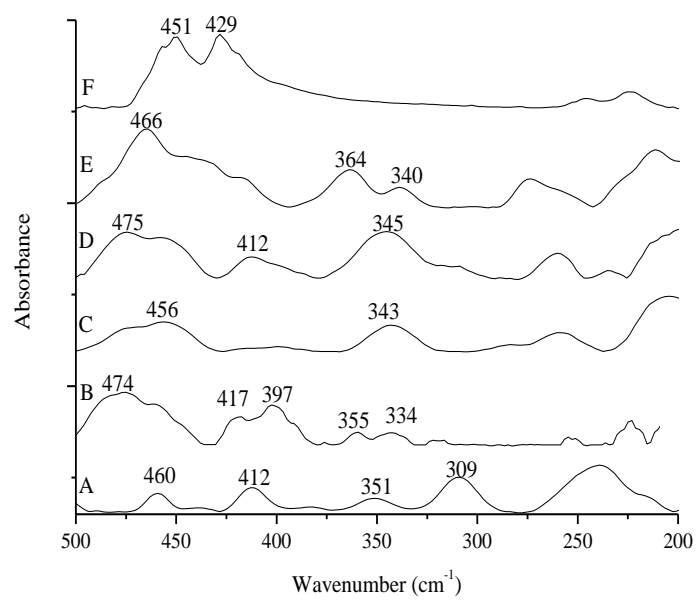

Figure 9 The far IR spectra of monosodium malonate complexes with A - Mn(II), B$\mathrm{Fe}(\mathrm{III}), \mathrm{C}-\mathrm{Co}(\mathrm{II}), \mathrm{D}-\mathrm{Ni}(\mathrm{II}), \mathrm{E}-\mathrm{Cu}(\mathrm{II})$ and the $\mathrm{F}-$ spectrum of monosodium malonate.

\subsection{Silica-anchored $M n(I I)$ complexes}

\subsubsection{Analytical measurements}

The results of the Kjeldahl method and the ICP-MS measurements for the immobilised $\mathrm{Mn}(\mathrm{II})$-complexes containing uniform amino acids as ligands are shown in Table 1.

Covalent grafting of the amino acids was successful in all cases. The conversion of immobilisation ranged from $57-86 \%$ for the C-protected amino acids, since the chloropropylated silica gel contained $0.705 \mathrm{mmol} / \mathrm{g}$ active chlorine. The metal ion to amino acid ratio under ligand-poor conditions is 1:1.5 and 1:1.4 for SG-His-OMe$\mathrm{Mn}(\mathrm{II})$ and SG-Tyr-OMe-Mn(II), respectively, suggesting that complexes formed on the surface are not uniform, that is: there are complexes having 1:1 as well as 1:2 metal ion to ligand ratios. For $\mathrm{SG}-\mathrm{Cys}-\mathrm{OMe}-\mathrm{Mn}(\mathrm{II})$ this ratio is $1: 1$ and for $\mathrm{SG}-(\mathrm{Cys}-\mathrm{OMe})_{2}-$ $\mathrm{Mn}(\mathrm{II})$ is $1: 1.1$, meaning that mainly $1: 1$ complexes are formed. Under ligand-excess 
conditions, these ratios are 1:5.4, 1:2, 1:3.2 and 1:2.5 for SG-His-OMe-Mn(II)-H-HisOMe, SG-Tyr-OMe-Mn(II)-H-Tyr-OMe, SG-Cys-OMe-Mn(II)-H-Cys-OMe and SG-(Cys-OMe $)_{2}-\mathrm{Mn}(\mathrm{II})-\mathrm{H}-(\mathrm{Cys}-\mathrm{OMe})_{2}$, respectively. It seems that in all cases a mixture of various complexes were formed on the surface of the support. For SG-His$\mathrm{OMe}-\mathrm{Mn}(\mathrm{II})-\mathrm{H}-\mathrm{His}-\mathrm{OMe}$, the 1:5.4 ratio may indicate that there are non-coordinating C-protected histidine molecules hydrogen-bonded to each other, since this ratio is much larger than those found for the others.

Table 1 Amino acid and $\mathrm{Mn}^{2+}$ content of the samples obtained from Kjeldahl type Ndetermination and ICP-MS measurements.

\begin{tabular}{lcc}
\hline Sample & $\begin{array}{c}\text { Amino acid content } \\
(\mathrm{mmol} / \mathrm{g})\end{array}$ & $\begin{array}{c}\mathrm{Mn}^{2+} \text { content } \\
(\mathrm{mmol} / \mathrm{g})\end{array}$ \\
\hline SG-His-OMe-Mn(II) & 0.496 & 0.321 \\
SG-His-OMe-Mn(II)-H-His-OMe & 1.726 & 0.410 \\
SG-Tyr-OMe-Mn(II) & 0.575 & 0.607 \\
SG-Tyr-OMe-Mn(II)-H-Tyr-OMe & 0.847 & \\
SG-Cys-OMe-Mn(II) & 0.605 & 0.363 \\
SG-Cys-OMe-Mn(II)-H-Cys-OMe & 1.955 & \\
SG-(Cys-OMe $)_{2}-\mathrm{Mn}(\mathrm{II})$ & 0.405 & 0.895 \\
SG-(Cys-OMe $)_{2}-\mathrm{Mn}(\mathrm{II})-\mathrm{H}-(\mathrm{Cys}-\mathrm{OMe})_{2}$ & & \\
\hline
\end{tabular}

\subsubsection{EPR measurements}

All EPR spectra, recorded for the different amino acid containing samples, could be characterised by the superposition of a very broad singlet signal and a well-resolved signal of six lines. The broad signal $\left(\mathrm{g}_{\text {iso }}=2.013 \pm 0.003\right.$ and linewidth $\mathrm{w}=450 \pm 130$ $\mathrm{G}$ ) is typical for coupled $\mathrm{Mn}^{2+}$ centres. The significant signal broadening is due to the dipolar interactions and a random orientation of the paramagnetic metal ions. The wellresolved component is probably originated from isolated $\mathrm{Mn}^{2+}$ centres. The six hyperfine lines with $\mathrm{g}_{\text {iso }}=1.9985 \pm 0.0001$ and $\mathrm{A}_{\text {iso }}=88.5 \pm 0.1 \mathrm{G}$ are due to the interaction of the electron spin with the nuclear $\operatorname{spin}\left({ }^{55} \mathrm{Mn}, \mathrm{I}=5 / 2\right)$. The observed $\mathrm{g}$ values are very close to that of the free electron, suggesting the absence of spin orbit coupling in the ground state. These features are characteristic of oxygen coordinated $\mathrm{Mn}^{2+}$ ion in disordered systems, and the $\mathrm{A}_{\mathrm{iso}}$ values suggest that the $\mathrm{Mn}(\mathrm{II})$ in the 
immobilised complexes is in an octahedral coordination environment [121, 134]. Exemplary experimental and simulated EPR spectra are shown in Figure 10.

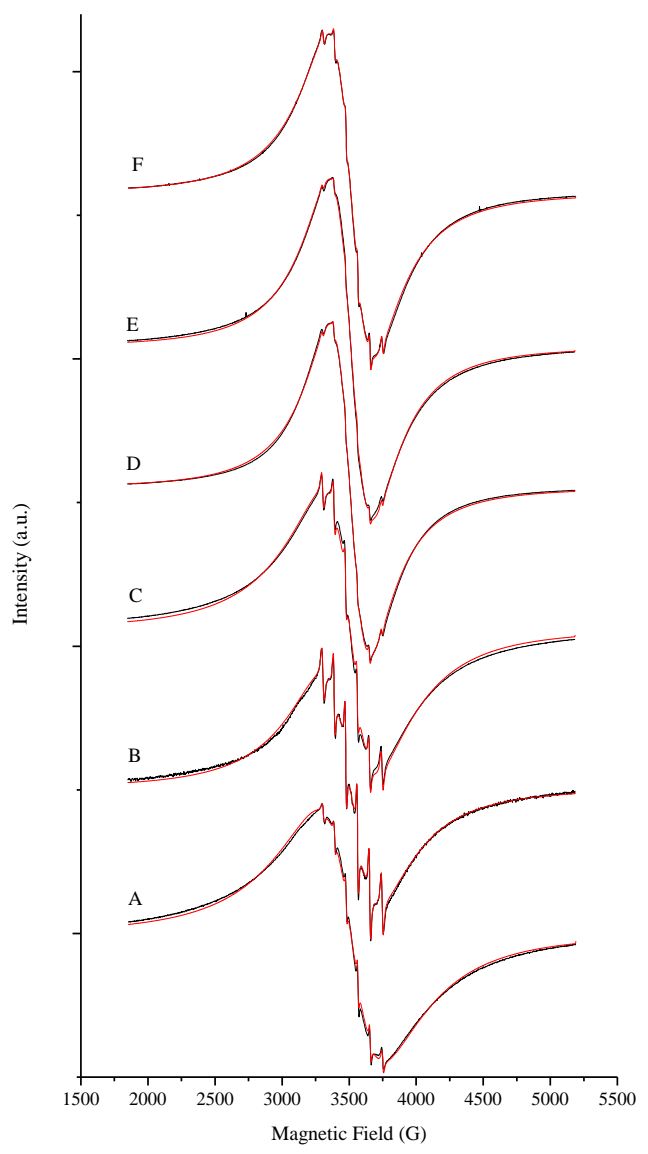

Figure 10 Experimental (black line) and simulated (red line) EPR spectra of A - SG-His-OMe-Mn(II), B - SG-His-OMe-Mn(II)-H-His-OMe, C - SG-Cys-OMe-Mn(II), D - SG-Cys-OMe-Mn(II)-H-Cys-OMe, E - SG-(Cys-OMe $)_{2}-\mathrm{Mn}(\mathrm{II}), \mathrm{F}-\mathrm{SG}-(\mathrm{Cys}-\mathrm{OMe})_{2}-\mathrm{Mn}(\mathrm{II})-\mathrm{H}-(\mathrm{Cys}-\mathrm{OMe})_{2}$.

\subsubsection{X-ray absorption measurements}

Mn K-edge XAS spectra were recorded only for some complexes focusing on the S-containing samples, in order to determine whether the sulphur atom was coordinated to the central ion. The XANES spectra of the materials are displayed in Figure 11. 


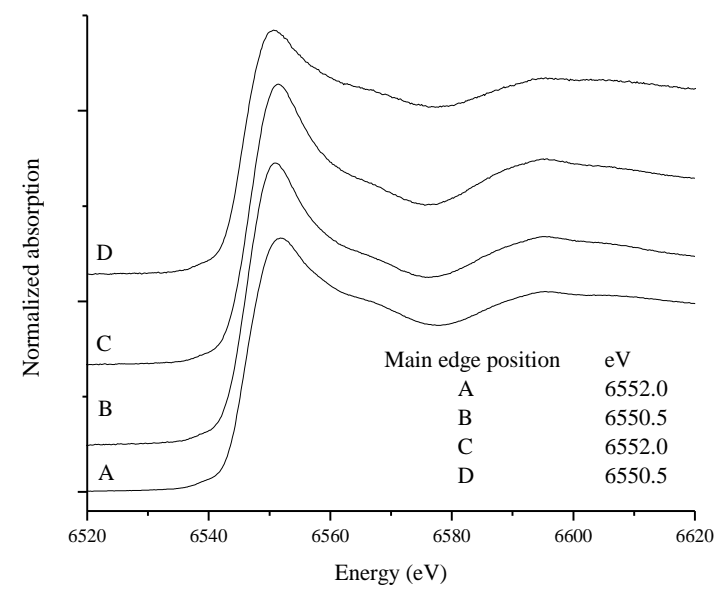

Figure $11 \mathrm{Mn}$ K-edge XANES spectra of A - SG-His-OMe-Mn(II), B - SG-Cys-OMe-Mn(II), C - SG-(Cys-OMe) $)_{2}-\mathrm{Mn}(\mathrm{II})$, D - SG-His-OMe-Mn(II)-H-Cys-OMe immobilised complexes.

The weak pre-edge feature in the Mn K-edge XANES spectra, corresponding to $1 \mathrm{~s} \rightarrow 3 \mathrm{~d}$ transitions around $6540 \mathrm{eV}$ indicates symmetric geometry and high coordination number, since these transitions are Laporte-forbidden in centrosymmetric environments, that is the immobilised $\mathrm{Mn}(\mathrm{II})$ complexes are octahedral. The intensity of the $1 \mathrm{~s} \rightarrow 3 \mathrm{~d}$ pre-edge transitions is inversely proportional to coordination number [135]. This is consistent with the EPR observations. The position of the main edge can provide information on the nature of the coordinating atoms. Substitution of O or N donor atoms by S-donor ligands induces a shift $(\sim 2 \mathrm{eV})$ in the edge energy to lower values [136]. The main edge position $(\sim 6552 \mathrm{eV})$ is shifted towards lower energies for SG-CysOMe-Mn(II) and SG-His-OMe-Mn(II)-H-Cys-OMe relative to the other two grafted complexes, indicating the coordination of the thiolate group.

The Fourier-transformed EXAFS data (without phase correction) are shown in Figure 12, and the results of fitting are reported in Table 2. 


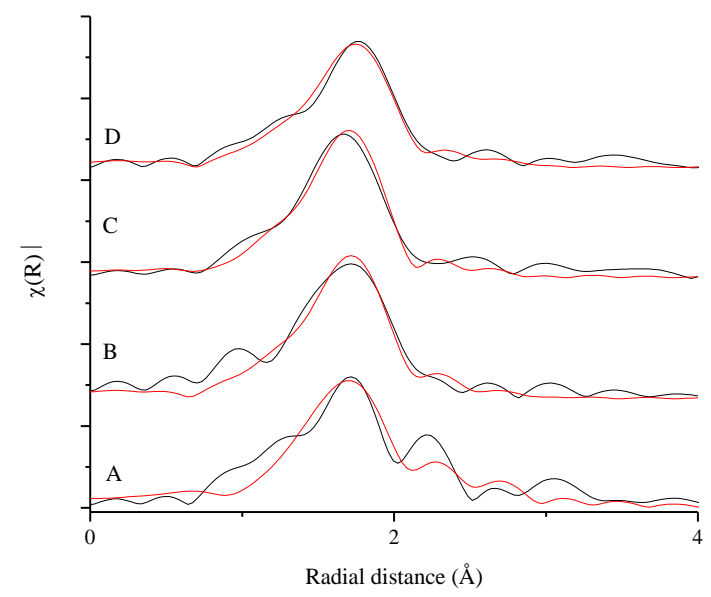

Figure 12 Fourier-transformed EXAFS data (without phase correction) of A - SG-His-OMe-Mn(II), B - SG-Cys-OMe-Mn(II), C - SG-(Cys-OMe) $)_{2}-\mathrm{Mn}(\mathrm{II})$, D - SG-His-OMe-Mn(II)-H-Cys-OMe, red line - fit, black line - experimental.

Table 2 Parameters deduced from the fitted EXAFS spectra $(\mathrm{N}$ - coordination number, $\mathrm{R}$ - bond length, $\sigma^{2}$ - Debye-Waller factor, $\Delta \mathrm{E}_{0}$ - energy shift, $\mathrm{R}$ factor - goodness of fit).

\begin{tabular}{lcccccc}
\hline Sample & $\left(\mathrm{Mn}^{2+}-\right) \mathrm{X}$ & $\mathrm{N}$ & $\mathrm{R}(\AA)$ & $\sigma^{2}\left(\AA^{2}\right)$ & $\Delta \mathrm{E}_{0}(\mathrm{eV})$ & $\mathrm{R}$ factor \\
\hline SG-His-OMe-Mn(II) & $\mathrm{O} / \mathrm{N}$ & 6 & 2.18 & 0.0153 & 3.40 & 0.0509 \\
SG-Cys-OMe-Mn(II) & $\mathrm{O} / \mathrm{N}$ & 5 & 2.21 & 0.0112 & 0.40 & 0.0118 \\
& $\mathrm{~S}$ & 1 & 2.64 & 0.0220 & & \\
& & & & & & \\
SG-(Cys-OMe) ${ }_{2}-\mathrm{Mn}(\mathrm{II})$ & $\mathrm{O} / \mathrm{N}$ & 6 & 2.19 & 0.0108 & 1.28 & 0.0139 \\
SG-His-OMe-Mn(II)- & $\mathrm{O} / \mathrm{N}$ & 5.4 & 2.22 & 0.0122 & 1.33 & 0.0101 \\
H-Cys-OMe & $\mathrm{S}$ & 0.6 & 2.66 & 0.0492 & & \\
\hline
\end{tabular}

The EXAFS measurements revealed that six oxygen/nitrogen atoms were (by these measurements the difference between oxygen and nitrogen cannot be estimated clearly, they scatter the photoelectrons nearly the same way, due to their similar atomic masses) in the first coordination sphere of SG-His-OMe-Mn(II), where the $\mathrm{Mn}(\mathrm{II})-\mathrm{O} / \mathrm{N}$ bond distance was fitted to be $2.18 \AA$. In SG-(Cys-OMe $)_{2}-\mathrm{Mn}$ (II) the first coordination shell contains six oxygen/nitrogen atoms as well with a $\mathrm{Mn}(\mathrm{II})-\mathrm{O} / \mathrm{N}$ bond length of 2.19 $\AA$ A. For SG-Cys-OMe-Mn(II) two different interatomic distances can be distinguished in the first shell. The first one corresponds to the $\mathrm{Mn}(\mathrm{II})-\mathrm{O} / \mathrm{N}$ distance of $2.21 \AA$ with a coordination number of five, while the second peak is related to a $\mathrm{Mn}(\mathrm{II})-\mathrm{S}$ distance ( $\mathrm{R}$ 
$=2.64 \AA$ ), where the coordination number is one. For SG-His-OMe-Mn(II)-H-CysOMe to the $\mathrm{Mn}(\mathrm{II})-\mathrm{O} / \mathrm{N}$ distance is $2.22 \AA$ with a coordination number of 5.4 and $\mathrm{Mn}(\mathrm{II})-\mathrm{S}$ distance is $2.66 \AA(\mathrm{N}=0.6)$. It can be concluded that the sulphur atom of cysteine was coordinated when the amino acid was covalently anchored, and when it was non-grafted to the surface of the support as well. These results are similar to those obtained with $\mathrm{Mn}(\mathrm{II})$ ion coordinated with various carboxylates or histidine as ligands [137].

\subsubsection{FT-IR spectroscopy}

The coordinating groups were identified through comparing the difference mid IR spectra (the spectrum of the support was subtracted) of the silica gel grafted amino acids and the difference spectra of the immobilised complexes prepared under ligand-poor conditions or the spectra of the pristine amino acids and the difference spectra of the anchored complexes prepared under ligand-excess conditions.

In the difference spectrum of $\mathrm{SG}-(\mathrm{His}-\mathrm{OMe})$ the $v_{\text {asym(COO-) }}$ and $v_{\mathrm{sym}(\mathrm{COO}-)}$ stretching frequencies can be seen at $1582 \mathrm{~cm}^{-1}$ and $1412 \mathrm{~cm}^{-1}$, respectively (Figure 4, trace A). To assign the $v_{\text {sym(COO-) }}$ vibrations, Raman spectra (not shown) were registered as well, since these vibrations are more intense there. $\Delta$ is $170 \mathrm{~cm}^{-1}$ here, while it is found to be $146 \mathrm{~cm}^{-1}\left(\Delta=1588 \mathrm{~cm}^{-1}-1442 \mathrm{~cm}^{-1}\right)$ for the complex prepared under ligand-poor conditions (Figure 13, trace A), suggesting that the carboxylate group coordinates as bidentate ligand. The band at $259 \mathrm{~cm}^{-1}$ in the far IR spectrum of the material (Figure 14, trace A) indicates that the imidazole nitrogen takes part in the complexation, the vibrations at 350 and $326 \mathrm{~cm}^{-1}$ correspond to the $\mathrm{Mn}-\mathrm{O}_{\text {carboxylate }}$ vibrations, while the bands above $400 \mathrm{~cm}^{-1}$ can be assigned as the $\mathrm{Mn}$-coordinated water vibrations, originated from the crystalline water of the Mn salt.

Adding C-protected histidine in excess (Figure 13, trace B) resulted in the rearrangement of the surface-grafted ligand-poor complex. This spectrum is very similar to that of the pristine C-protected histidine (Figure 5, trace A), the carbonyl band (1761 $\mathrm{cm}^{-1}$ ) did not move, meaning that the carbonyl oxygen is not coordinated to the centre ion. (In the last step of the synthesis neutral conditions were applied, that is the nonanchored C-protected amino acids were not deprotected). The $\mathrm{Mn}(\mathrm{II})-\mathrm{N}_{\text {imidazole }}$ vibration 
is observed at $266 \mathrm{~cm}^{-1}$, the bands above $400 \mathrm{~cm}^{-1}$ can be assigned as coordinated water and/or ligand vibrations (Figure 14, trace B).

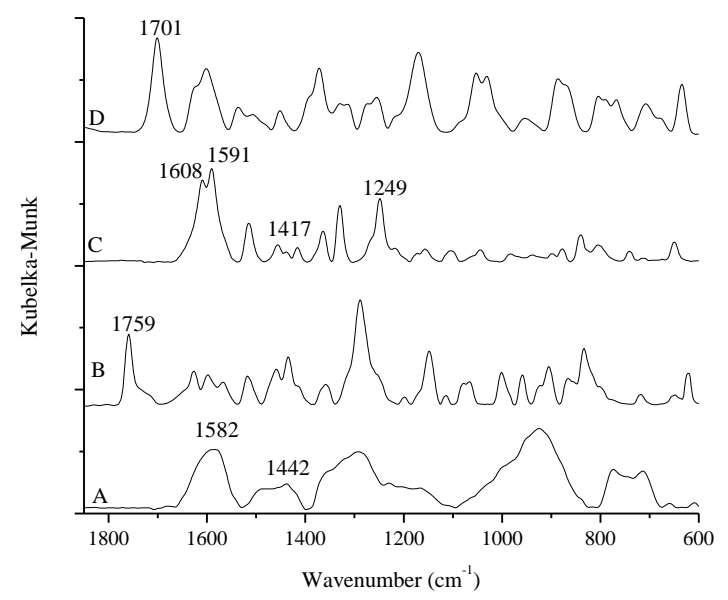

Figure 13 The IR spectra of A - SG-His-OMe-Mn(II), B - SG-His-OMe-Mn(II)-H-His-OMe, C - SG-Tyr-OMe-Mn(II), D - SG-Tyr-OMe-Mn(II)-H-Tyr-OMe.

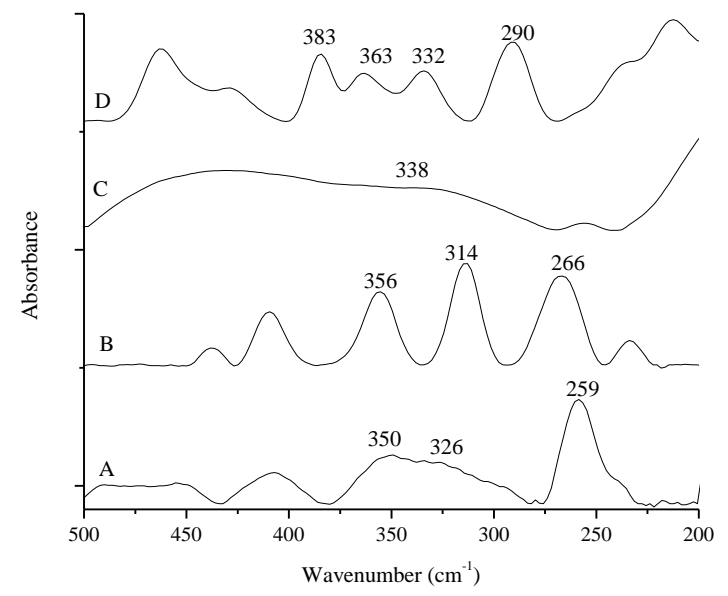

Figure 14 The far IR spectra of A - SG-His-OMe-Mn(II), B - SG-His-OMe-Mn(II)-H-His-OMe, C - SG-Tyr-OMe-Mn(II), D - SG-Tyr-OMe-Mn(II)-H-Tyr-OMe.

$\Delta$ is $1577 \mathrm{~cm}^{-1}-1426 \mathrm{~cm}^{-1}=151 \mathrm{~cm}^{-1}$ for $\mathrm{SG}-($ Tyr-OMe) (Figure 4 , trace $\mathrm{B}$ ), while it is $1608 \mathrm{~cm}^{-1}-1417 \mathrm{~cm}^{-1}=191 \mathrm{~cm}^{-1}$ for SG-(Tyr-OMe)-Mn(II) (Figure 13, trace $\mathrm{C}$ ), indicating that the carboxylate group acts as monodentate ligand. The phenolic $\mathrm{C}-\mathrm{O}$ is coordinated to the centre ion, since its vibration moved to $1249 \mathrm{~cm}^{-1}$ from 1280 $\mathrm{cm}^{-1}$. In the far IR range, a broad band can be seen from $300-500 \mathrm{~cm}^{-1}$ due to the different $\mathrm{Mn}-\mathrm{O}$ vibrations. 
The carbonyl band appears at $1745 \mathrm{~cm}^{-1}$ in the spectrum of H-Tyr-OMe (Figure 5, trace B). In the spectrum of the complex prepared under ligand-excess conditions (Figure 13, trace D), it is shifted to $1701 \mathrm{~cm}^{-1}$, meaning that the carbonyl oxygen takes part in the complexation. Now, the far IR spectrum is more resolved, the vibrations at 383 and $290 \mathrm{~cm}^{-1}$ indicate the coordination of the amino nitrogen. The bands at 363 and $332 \mathrm{~cm}^{-1}$ are the $\mathrm{Mn}-\mathrm{O}$ vibrations. Water molecules saturate the coordination sphere of the metal ion in this case as well.

Putting together all the information, for the surface-bound complexes the following structures are suggested:

SG-His-OMe-Mn(II)

$\mathrm{N}_{\text {imidazoleHissurf }} \mathrm{O}_{\text {carboxylateHissurf }} \mathrm{O}_{\text {carboxylateHissurf }} \mathrm{H}_{2} \mathrm{O}, \mathrm{H}_{2} \mathrm{O}, \mathrm{H}_{2} \mathrm{O}$,

SG-His-OMe-Mn(II)-H-His-OMe

$\mathrm{N}_{\text {imidazoleHissurf }} \mathrm{O}_{\text {carboxylateHissurf }} \mathrm{O}_{\text {carboxylateHissurf }} \mathrm{N}_{\text {imidazoleHis }} \mathrm{N}_{\text {imidazoleHis }} \mathrm{H}_{2} \mathrm{O}$,

SG-Tyr-OMe-Mn(II)

$\mathrm{O}_{\text {carboxylateTyrsurf }} \mathrm{O}_{\text {phenolateTyrsurf }} \mathrm{H}_{2} \mathrm{O}, \mathrm{H}_{2} \mathrm{O}, \mathrm{H}_{2} \mathrm{O}, \mathrm{H}_{2} \mathrm{O}$,

SG-Tyr-OMe-Mn(II)-H-Tyr-OMe

$\mathrm{O}_{\text {carboxylateTyrsurf }} \mathrm{O}_{\text {phenolateTyrsurf }} \mathrm{O}_{\text {carbonylTyr }} \mathrm{N}_{\text {aminoTyr }} \mathrm{H}_{2} \mathrm{O}, \mathrm{H}_{2} \mathrm{O}$,

where 'surf' stands for surface.

For SG-Cys-OMe-Mn(II) (Figure 15, trace A), $\Delta$ is $1610 \mathrm{~cm}^{-1}-1409 \mathrm{~cm}^{-1}=201$ $\mathrm{cm}^{-1}$ suggesting the monodentate carboxylate coordination, since for the ligand (Figure 4 , trace C) $\Delta=190 \mathrm{~cm}^{-1}$. There is no $\mathrm{S}-\mathrm{H}$ vibration at around $2500 \mathrm{~cm}^{-1}$; therefore the thiolate sulphur is coordinated, as it was also learnt from the XAS measurement. In the far IR range (Figure 16, trace A), the broad band between 360 and $300 \mathrm{~cm}^{-1}$ indicates the coordination of the carboxylate oxygen as well as the thiolate sulphur.

Under ligand-excess conditions (Figure 15, trace B), the carbonyl oxygen does not take part in the complexation, since the position of the band $\left(1747 \mathrm{~cm}^{-1}\right)$ does not move relative to that in the pristine amino acid (Figure 5, trace C). The lack of the $\mathrm{S}-\mathrm{H}$ vibration proves that the thiolate group is also coordinated. In the far IR range (Figure 16, trace B) a broad band can be seen between 370 and $300 \mathrm{~cm}^{-1}$ corresponding to the $\mathrm{Mn}(\mathrm{II})-\mathrm{S}_{\text {thiolate }}$ and $\mathrm{Mn}(\mathrm{II})-\mathrm{O}_{\text {carboxylate }}$ vibrations. The bands above $400 \mathrm{~cm}^{-1}$ can be assigned as the $\mathrm{Mn}-$ coordinated water/ligand vibrations. 


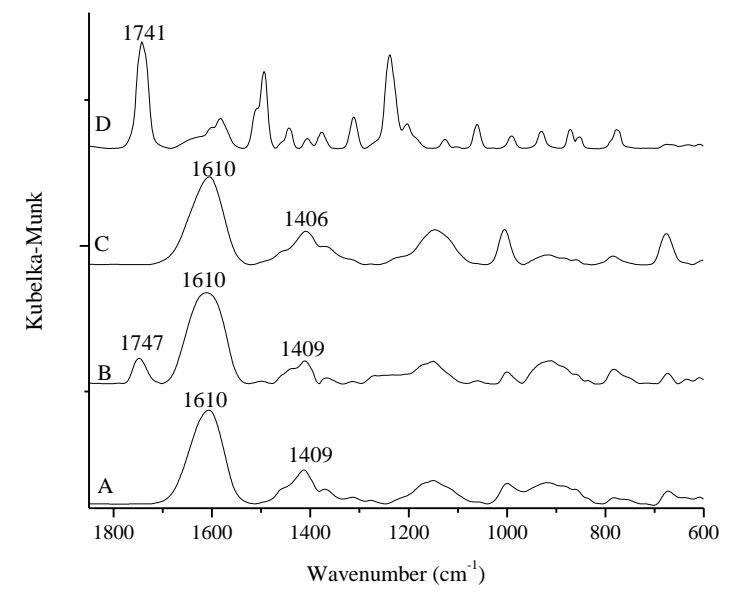

Figure 15 The IR spectra of A - SG-Cys-OMe-Mn(II), B - SG-Cys-OMe-Mn(II)-H-Cys-OMe, C - SG-(Cys-OMe $)_{2}-\mathrm{Mn}(\mathrm{II})$, $\mathrm{D}-\mathrm{SG}-(\mathrm{Cys}-\mathrm{OMe})_{2}-\mathrm{Mn}(\mathrm{II})-(\mathrm{H}-\mathrm{Cys}-\mathrm{OMe})_{2}$.

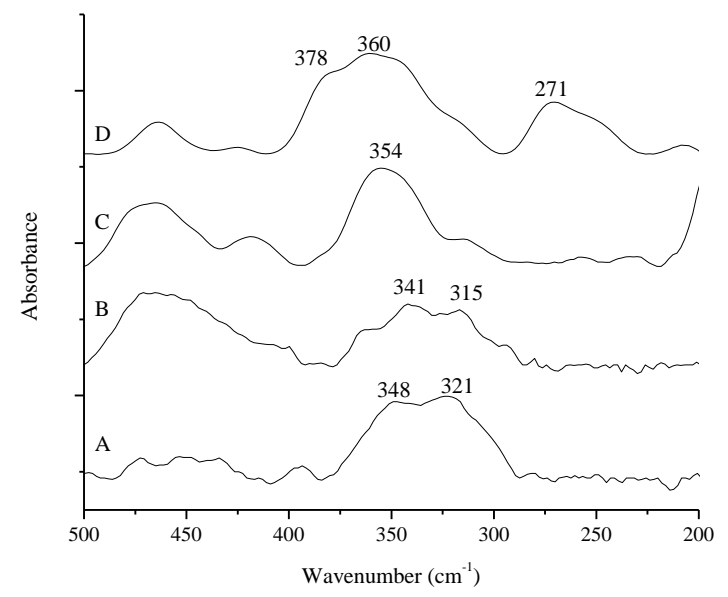

Figure 16 The far IR spectra of A - SG-Cys-OMe-Mn(II), B - SG-Cys-OMe-Mn(II)-H-Cys-OMe, C - SG-(Cys-OMe $)_{2}-\mathrm{Mn}(\mathrm{II})$, $\mathrm{D}-\mathrm{SG}-(\mathrm{Cys}-\mathrm{OMe})_{2}-\mathrm{Mn}(\mathrm{II})-(\mathrm{H}-\mathrm{Cys}-\mathrm{OMe})_{2}$.

As far as $\mathrm{SG}-(\mathrm{Cys}-\mathrm{OMe})_{2}-\mathrm{Mn}(\mathrm{II})$ is concerned (Figure 15, trace C) the carboxylate groups are coordinated in a monodentate manner, since $\Delta$ increased from $185 \mathrm{~cm}^{-1}$ (Figure 4, trace D) to $204 \mathrm{~cm}^{-1}$. In the far IR range, the peak at $354 \mathrm{~cm}^{-1}$ corresponds to the $\mathrm{Mn}(\mathrm{II})-\mathrm{O}_{\text {carboxylate }}$ vibration. Under ligand-excess conditions (Figure 15 , trace D) the carbonyl oxygens are not involved in the coordination, since the stretching vibrations of the carbonyl bands $\left(1746\right.$ and $\left.1734 \mathrm{~cm}^{-1}\right)$ did not shift to lower wavenumbers relative to those in the pristine amino acid (Figure 5, trace D). This is the reason why it is suggested that the added $\mathrm{C}$-protected cystine molecules were 
coordinated with their amino nitrogens. It was confirmed by far IR measurement, since two new bands appeared at 378 and $271 \mathrm{~cm}^{-1}$ due to the coordination of amino nitrogen.

The proposed coordination modes are the followings:

SG-Cys-OMe-Mn(II)

$\mathrm{S}_{\text {thiolateCyssurf }} \mathrm{O}_{\text {carboxylateCysssurf }} \mathrm{H}_{2} \mathrm{O}, \mathrm{H}_{2} \mathrm{O}, \mathrm{H}_{2} \mathrm{O}, \mathrm{H}_{2} \mathrm{O}$,

SG-Cys-OMe-Mn(II)-H-Cys-OMe

$\mathrm{S}_{\text {thiolateCyssurf }} \mathrm{O}_{\text {carboxylateCysssurf }} \mathrm{S}_{\text {thiolateCys }} \mathrm{H}_{2} \mathrm{O}, \mathrm{H}_{2} \mathrm{O}, \mathrm{H}_{2} \mathrm{O}$,

SG-(Cys-OMe $)_{2}-\mathrm{Mn}(\mathrm{II})$

$\mathrm{O}_{\text {carboxylate(Cys)2surf }} \mathrm{O}_{\text {carboxylate(Cys)2surf }} \mathrm{H}_{2} \mathrm{O}, \mathrm{H}_{2} \mathrm{O}, \mathrm{H}_{2} \mathrm{O}, \mathrm{H}_{2} \mathrm{O}$,

SG-(Cys-OMe $)_{2}-\mathrm{Mn}(\mathrm{II})-(\mathrm{H}-\mathrm{Cys}-\mathrm{OMe})_{2}$

$\mathrm{O}_{\text {carboxylate(Cys)2surf }} \mathrm{O}_{\text {carboxylate(Cys)2surf }} \mathrm{N}_{\text {amino(Cys) } 2} \mathrm{~N}_{\text {amino(Cys)2 }} \mathrm{H}_{2} \mathrm{O}, \mathrm{H}_{2} \mathrm{O}$.

In the difference spectrum of SG-His-OMe-Mn(II)-H-Tyr-OMe the $v_{\text {asym(COO-) }}$ and $v_{\mathrm{sym}(\mathrm{COO}-)}$ stretching frequencies of the surface anchored amino acid are seen at 1586 $\mathrm{cm}^{-1}$ and $1440 \mathrm{~cm}^{-1}$, respectively (Figure 17, trace A). $\Delta=146 \mathrm{~cm}^{-1}$, suggesting that the carboxylate group bidentately coordinated. The carbonyl band of H-Tyr-OMe did not move, indicating that the amino acid takes part in the complexation through its amino nitrogen. In the far IR spectrum of the material, the band at $262 \mathrm{~cm}^{-1}$ (Figure 15, trace A) corresponds to the $\mathrm{Mn}(\mathrm{II})-\mathrm{N}_{\text {imidazole }}$ vibration, the band at $330 \mathrm{~cm}^{-1}$ confirms the coordination of the carboxylate oxygens, the vibrations of the coordinated amino nitrogen appear at 382 and $275 \mathrm{~cm}^{-1}$.

In the case of SG-Tyr-OMe-Mn(II)-H-His-OMe (Fig 17, trace B) the vibrations of the anchored tyrosine are covered by the vibrations of the non-grafted H-His-OMe. It can be assumed that the tyrosine is coordinated the same way as in the SG-Tyr-OMe$\mathrm{Mn}(\mathrm{II})$ complex. The carbonyl band of H-His-OMe $\left(1761 \mathrm{~cm}^{-1}\right)$ did not move, meaning that the carbonyl oxygen was not involved in the complexation. In the far IR range, the $\mathrm{Mn}(\mathrm{II})-\mathrm{O}_{\text {carboxylate}}, \mathrm{Mn}(\mathrm{II})-\mathrm{N}_{\text {imidazole }}$ and coordinated water vibrations are observed (Figure 18, trace B).

It is more difficult to evaluate the spectra of the complexes prepared by method ' $B$ ', since the amino acids were added in 1:1 molar ratio both in the fist and the last step of the synthesis and their vibrations are overlapped. Here, numerous types of complexes can be imagined on the support surface. In SG-His-OMe;Tyr-OMe-Mn(II) (Figure 17, trace $\mathrm{C}$ ), histidine and tyrosine are coordinated with their carboxylate oxygens as bidentate and mondentate ligands, since $\Delta$ is 146 and $195 \mathrm{~cm}^{-1}$, respectively. Regarding 
the far IR spectrum of the complex (Figure 18, trace C), the coordination of the imidazole nitrogen $\left(261 \mathrm{~cm}^{-1}\right)$ is confirmed.

Under ligand-excess conditions (Figure 17, trace D), the carbonyl bands did not shift. In the far IR spectrum, a new band appeared corresponding to the $\mathrm{Mn}(\mathrm{II})-\mathrm{N}_{\mathrm{amino}}$ vibration.

In all instances, the bands above $400 \mathrm{~cm}^{-1}$ indicate that water molecules saturate the coordination sphere.

The above-detailed reasoning suggests coordination environments as follows:

SG-His-OMe-Mn(II)-H-Tyr-OMe

$\mathrm{N}_{\text {imidazoleHissurf }} \mathrm{O}_{\text {carboxylateHissurf }} \mathrm{O}_{\text {carboxylateHissurf }} \mathrm{N}_{\text {aminoTyr }} \mathrm{N}_{\text {aminoTyr }}, \mathrm{H}_{2} \mathrm{O}$,

SG-Tyr-OMe-Mn(II)-H-His-OMe

$\mathrm{O}_{\text {carboxylateTyrsurf }} \mathrm{O}_{\text {phenolateTyrsurf }} \mathrm{N}_{\text {imidazoleHis }}, \mathrm{N}_{\text {imidazoleHis }}, \mathrm{H}_{2} \mathrm{O}, \mathrm{H}_{2} \mathrm{O}$,

SG-His-OMe;Tyr-OMe-Mn(II)

$\mathrm{N}_{\text {imidazoleHissurf }} \mathrm{O}_{\text {carboxylateHissurf }} \mathrm{O}_{\text {carboxylateHissurf }} \mathrm{O}_{\text {carboxylateTyrsurf }} \mathrm{O}_{\text {phenolateTyrsurf }} \mathrm{H}_{2} \mathrm{O}$,

SG-His-OMe;Tyr-OMe-Mn(II)-H-His-OMe;H-Tyr-OMe

$\mathrm{N}_{\text {imidazoleHissurf }} \mathrm{O}_{\text {carboxylateHissurf }} \mathrm{O}_{\text {carboxylateTyrsurf }} \mathrm{N}_{\text {imidazoleHis }} \mathrm{N}_{\text {aminoTyr }} \mathrm{H}_{2} \mathrm{O}$.

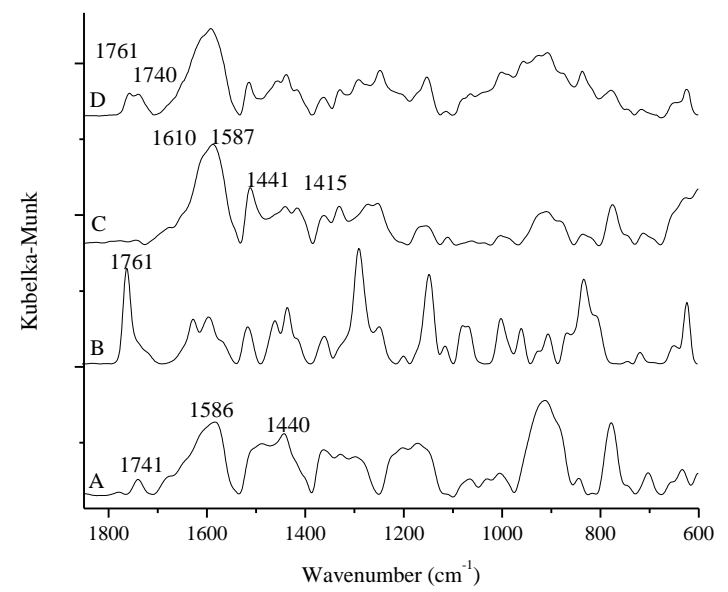

Figure 17 The IR spectra of A - SG-His-OMe-Mn(II)-H-Tyr-OMe, B - SG-Tyr-OMe-Mn(II)-H-His-OMe, C - SG-His-OMe;Tyr-OMe-Mn(II), D - SG-His-OMe;Tyr-OMe-Mn(II)-H-His-OMe; H-Tyr-OMe. 


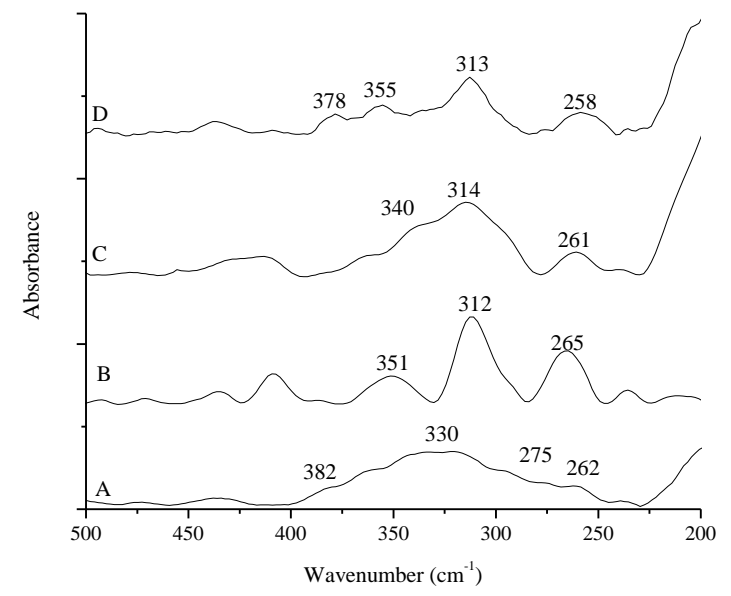

Figure 18 The far IR spectra of A - SG-His-OMe-Mn(II)-H-Tyr-OMe, B - SG-Tyr-OMe-Mn(II)-H-His-OMe, C - SG-His-OMe;Tyr-OMe-Mn(II), D - SG-His-OMe;Tyr-OMe-Mn(II)-H-His-OMe; H-Tyr-OMe.

In Figure 19, trace A depicts the difference spectrum of SG-His-OMe-Mn(II)-HCys-OMe. The structure of SG-His-OMe-Mn(II) was determined above (p. 35). It is clear that adding C-protected cysteine in excess rearranged the surface complex. The stretching vibration of the carbonyl band shifted $3 \mathrm{~cm}^{-1}$ to $1741 \mathrm{~cm}^{-1}$ from $1744 \mathrm{~cm}^{-1}$, which is far too small to indicate its coordination. Both the absence of the $\mathrm{S}-\mathrm{H}$ vibration and the results of the EXAFS measurement confirm that the thiolate sulphur participates in the complexation. It can be learnt from the far IR spectrum (Figure 20, trace A) that the amino nitrogen is not coordinated.

For SG-Cys-OMe-Mn(II)-H-His-OMe (Figure 19, trace B), the carbonyl oxygen of C-protected histidine takes part in the complexation, since the position of the carbonyl band, which was found to be at $1761 \mathrm{~cm}^{-1}$ in the spectrum of the free ligand, moved to $1748 \mathrm{~cm}^{-1}$. The band at $254 \mathrm{~cm}^{-1}$ indicates the coordination of the imidazole nitrogen (Figure 20, trace B).

Studying the mid IR difference spectra of SG-His-OMe;Cys-OMe-Mn(II) (Figure 19 , trace C) reveals that the carboxylate vibrations of the amino acids are overlapped. The same coordination mode may be assumed for the ligands as it was determined, when they were used separately. As far as the spectrum of the anchored complex prepared under ligand-excess conditions is concerned (Figure 19, trace D), the carbonyl bands did not $\left(1759,1741 \mathrm{~cm}^{-1}\right)$ shift. In the far IR range (Figure 20, traces C and D) 
there are bands attributed to the vibrations of $\mathrm{M}-\mathrm{O}_{\text {carboxylate }}, \mathrm{M}-\mathrm{N}_{\text {imidazole }}$ and coordinated water.

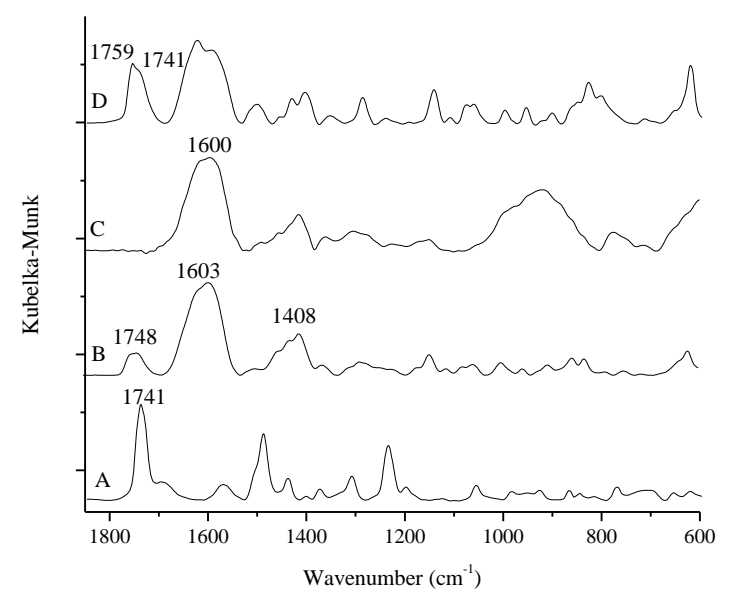

Figure 19 The IR spectra of A - SG-His-OMe-Mn(II)-H-Cys-OMe, B - SG-Cys-OMe-Mn(II)-H-His-OMe, C - SG-His-OMe;Cys-OMe-Mn(II), D - SG-His-OMe;Cys-OMe-Mn(II)-H-His-OMe;H-Cys-OMe.

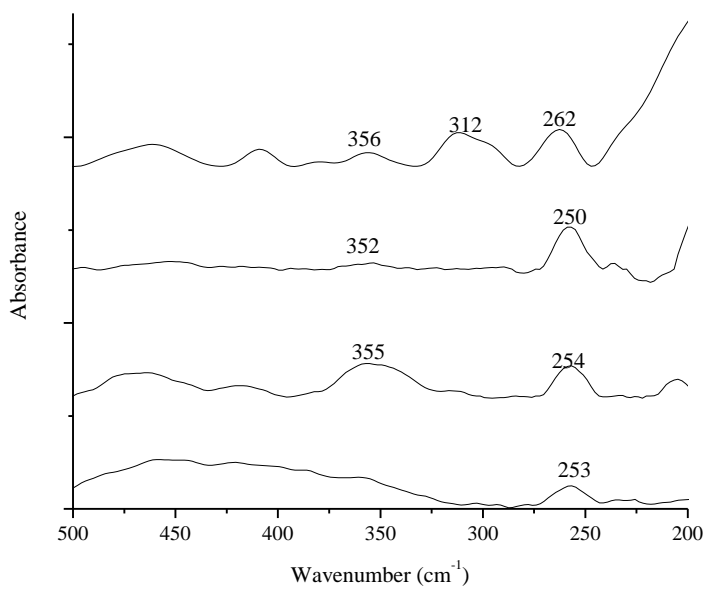

Figure 20 The far IR spectra of A - SG-His-OMe-Mn(II)-H-Cys-OMe, B - SG-Cys-OMe-Mn(II)-H-His-OMe, C - SG-His-OMe;Cys-OMe-Mn(II), D - SG-His-OMe;Cys-OMe-Mn(II)-H-His-OMe;H-Cys-OMe.

The proposed structures are as follows:

SG-His-OMe-Mn(II)-H-Cys-OMe

$\mathrm{N}_{\text {imidazoleHissurf }} \mathrm{O}_{\text {carboxylateHissurf }} \mathrm{O}_{\text {carboxylateHissurf }} \mathrm{S}_{\text {thiolateCys }} \mathrm{H}_{2} \mathrm{O}, \mathrm{H}_{2} \mathrm{O}$,

SG-Cys-OMe-Mn(II)-H-His-OMe

$\mathrm{S}_{\text {thiolateCyssurf }} \mathrm{O}_{\text {carboxylateCysssurf }} \mathrm{N}_{\text {imidazoleHis }} \mathrm{O}_{\text {carbonylHis }} \mathrm{H}_{2} \mathrm{O}, \mathrm{H}_{2} \mathrm{O}$, 
SG-His-OMe;Cys-OMe-Mn(II)

$\mathrm{N}_{\text {imidazoleHissurf }} \mathrm{O}_{\text {carboxylateHissurf }} \mathrm{O}_{\text {carboxylateHissurf }} \mathrm{S}_{\text {thiolateCyssurf }} \mathrm{O}_{\text {carboxylateCysssurf }} \mathrm{H}_{2} \mathrm{O}$,

SG-His-OMe;Cys-OMe-Mn(II)-H-His-OMe; H-Cys-OMe

$\mathrm{N}_{\text {imidazoleHissurf }} \mathrm{O}_{\text {carboxylateHissurf }} \mathrm{S}_{\text {thiolateCyssurf }} \mathrm{N}_{\text {imidazoleHis }} \mathrm{S}_{\text {thiolateCys }} \mathrm{H}_{2} \mathrm{O}$.

In Figure 21, trace $\mathrm{A}$ is the spectrum of SG-His-OMe-Mn(II)-(H-Cys-OMe $)_{2}$. Adding C-protected cystine to SG-His-OMe-Mn(II) rearranged the surface complex. The stretching vibration of the carbonyl bands $\left(1745,1735 \mathrm{~cm}^{-1}\right)$ did not move relative to the free C-protected cystine. It can coordinate only with the amino nitrogens as the far IR spectrum (Figure 22, trace A) attests - the $\mathrm{Mn}(\mathrm{II})-\mathrm{N}_{\text {amino }}$ vibrations appear at 382 and $271 \mathrm{~cm}^{-1}$.

For SG-(Cys-OMe $)_{2}-\mathrm{Mn}(\mathrm{II})-\mathrm{H}-\mathrm{His}-\mathrm{OMe}$ (Figure 21, trace B), a relatively weak carbonyl oxygen vibration can be observed, shifted to $1741 \mathrm{~cm}^{-1}$. The band at $257 \mathrm{~cm}^{-1}$ indicates the coordination of the imidazole nitrogen as well. (Figure 22, trace B).

In $\mathrm{SG}-\mathrm{His}-\mathrm{OMe} ;(\mathrm{Cys}-\mathrm{OMe})_{2}-\mathrm{Mn}(\mathrm{II})$ the anchored amino acids are proposed to coordinate with the carboxylate groups and the imidazole nitrogen (Figures 21, 22, trace C).

Under ligand-excess conditions (Figure 21, trace D), there is a broad vibration at $1745 \mathrm{~cm}^{-1}$, which can be attributed to the unshifted carbonyl bands of C-protected cystine and C-protected histidine as well. From the far IR range (Figure 22, trace D), the coordination of the amino nitrogen $\left(383 \mathrm{~cm}^{-1}\right)$, the carboxylate oxygen $\left(358 \mathrm{~cm}^{-1}\right)$, the imidazole nitrogen $\left(257 \mathrm{~cm}^{-1}\right.$ ) and water (above $400 \mathrm{~cm}^{-1}$ ) can be learnt.

On the basis of the observations and the accumulated knowledge described at the complexes formed with uniform ligands, the following structures for the covalently immobilised complexes may be proposed:

SG-His-OMe-Mn(II)-(H-Cys-OMe $)_{2}$

$\mathrm{N}_{\text {imidazoleHissurf }} \mathrm{O}_{\text {carboxylateHissurf }} \mathrm{O}_{\text {carboxylateHissurf }} \mathrm{N}_{\text {amino(Cys) } 2} \mathrm{~N}_{\text {amino(Cys) } 2} \mathrm{H}_{2} \mathrm{O}$,

SG-(Cys-OMe $)_{2}-\mathrm{Mn}(\mathrm{II})-\mathrm{H}-\mathrm{His}-\mathrm{OMe}$

$\mathrm{O}_{\text {carboxylate(Cys)2surf }} \mathrm{O}_{\text {carboxylate(Cys)2surf }} \mathrm{N}_{\text {imidazoleHis }} \mathrm{O}_{\text {carbonylHis }} \mathrm{H}_{2} \mathrm{O}, \mathrm{H}_{2} \mathrm{O}$,

SG-His-OMe;(Cys-OMe) ${ }_{2}-\mathrm{Mn}(\mathrm{II})$

$\mathrm{N}_{\text {imidazoleHissurf }} \mathrm{O}_{\text {carboxylateHissurf }} \mathrm{O}_{\text {carboxylateHissurf }} \mathrm{O}_{\text {carboxylate(Cys)2surf }} \mathrm{O}_{\text {carboxylate(Cys)2surf }} \mathrm{H}_{2} \mathrm{O}$,

SG-His-OMe;(Cys-OMe $)_{2}-\mathrm{Mn}(\mathrm{II})-\mathrm{H}-\mathrm{His}-\mathrm{OMe} ;(\mathrm{H}-\mathrm{Cys}-\mathrm{OMe})_{2}$

$\mathrm{N}_{\text {imidazoleHissurf }} \mathrm{O}_{\text {carboxylateHissurf }} \mathrm{O}_{\text {carboxylate(Cys)2surf }} \mathrm{N}_{\text {imidazoleHis }} \mathrm{N}_{\text {amino(Cys) } 2} \mathrm{H}_{2} \mathrm{O}$. 


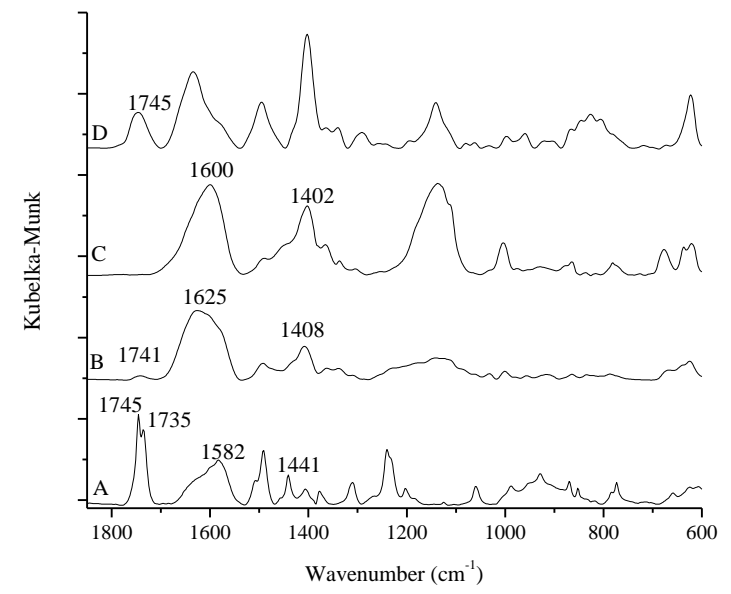

Figure 21 The IR spectra of A - SG-His-OMe-Mn(II)-(H-Cys-OMe $)_{2}$, $\mathrm{B}$ - SG-(Cys-OMe $)_{2}-\mathrm{Mn}$ (II)-H-His-OMe, C - SG-His-OMe;(Cys-OMe) ${ }_{2}-\mathrm{Mn}(\mathrm{II})$, $\mathrm{D}$ - SG-His-OMe;(Cys-OMe $)_{2}-\mathrm{Mn}(\mathrm{II})-\mathrm{H}-\mathrm{His}-\mathrm{OMe} ;(\mathrm{H}-\mathrm{Cys}-\mathrm{OMe})_{2}$.

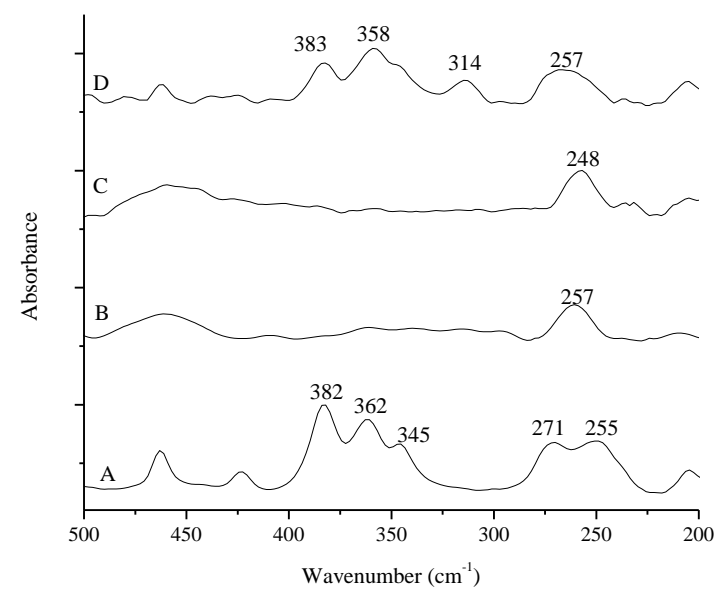

Figure 22 The far IR spectra of A - SG-His-OMe-Mn(II)-H-(Cys-OMe) $)_{2}$, $\mathrm{B}$ - SG-(Cys-OMe) $)_{2}-\mathrm{Mn}$ (II)-H-His-OMe, C - SG-His-OMe;(Cys-OMe $)_{2}-\mathrm{Mn}(\mathrm{II})$, $\mathrm{D}$ - SG-His-OMe;(Cys-OMe $)_{2}-\mathrm{Mn}(\mathrm{II})-\mathrm{H}-\mathrm{His}-\mathrm{OMe} ;(\mathrm{H}-\mathrm{Cys}-\mathrm{OMe})_{2}$.

\subsubsection{Testing the superoxide dismutase activity}

All materials displayed catalytic activity, i.e., could catalyse the dismutation of the superoxide radical anion. Catalytic activities are close to each other (Table 3). It seems that all the immobilised complexes promote this reaction similarly. The superoxide dismutase activities do not depend on the coordinating groups. There is no common structural feature in the first five most active complexes. The most active anchored complex was found to be SG-His-OMe-Mn(II)-H-His-OMe. 
Table 3 The SOD activities of the surface grafted complexes. The best catalysts are highlighted in red.

\begin{tabular}{|c|c|}
\hline Materials & $\mathrm{IC}_{50}(\mu \mathrm{M})$ \\
\hline Cu,ZnSOD enzyme & 0.4 \\
\hline SG-His-OMe-Mn(II) & 31 \\
\hline SG-His-OMe-Mn(II)-H-His-OMe & 26 \\
\hline SG-Tyr-OMe-Mn(II) & 35 \\
\hline SG-Tyr-OMe-Mn(II)-H-Tyr-OMe & 45 \\
\hline SG-Cys-OMe-Mn(II) & 39 \\
\hline SG-Cys-OMe-Mn(II)-H-Cys-OMe & 30 \\
\hline $\mathrm{SG}-(\mathrm{Cys}-\mathrm{OMe})_{2}-\mathrm{Mn}(\mathrm{II})$ & 32 \\
\hline $\mathrm{SG}-(\mathrm{Cys}-\mathrm{OMe})_{2}-\mathrm{Mn}(\mathrm{II})-\mathrm{H}-(\mathrm{Cys}-\mathrm{OMe})_{2}$ & 29 \\
\hline SG-His-OMe-Mn(II)-H-Tyr-OMe & 38 \\
\hline SG-Tyr-OMe-Mn(II)-H-His-OMe & 39 \\
\hline SG-His-OMe;Tyr-OMe-Mn(II) & 37 \\
\hline SG-His-OMe;Tyr-OMe-Mn(II)-H-His-OMe;H-Tyr-OMe & 45 \\
\hline SG-His-OMe-Mn(II)-H-Cys-OMe & 48 \\
\hline SG-Cys-OMe-Mn(II)-H-His-OMe & 30 \\
\hline SG-His-OMe;Cys-OMe-Mn(II) & 41 \\
\hline SG-His-OMe;Cys-OMe-Mn(II)-H-His-OMe;H-Cys-OMe & 28 \\
\hline SG-His-OMe-Mn(II)-(H-Cys-OMe $)_{2}$ & 31 \\
\hline $\mathrm{SG}-(\mathrm{Cys}-\mathrm{OMe})_{2}-\mathrm{Mn}(\mathrm{II})-\mathrm{H}-\mathrm{His}-\mathrm{OMe}$ & 36 \\
\hline SG-His-OMe;(Cys-OMe) $)_{2}-\mathrm{Mn}(\mathrm{II})$ & 58 \\
\hline $\mathrm{SG}-\mathrm{His}-\mathrm{OMe} ;(\mathrm{Cys}-\mathrm{OMe})_{2}-\mathrm{Mn}(\mathrm{II})-\mathrm{H}-\mathrm{His}-\mathrm{OMe} ;(\mathrm{H}-\mathrm{Cys}-\mathrm{OMe})_{2}$ & 62 \\
\hline
\end{tabular}

\subsubsection{Catalytic oxidation of cyclohexene}

The conversion and selectivity results of the immobilised catalysts in the oxidation of cyclohexene with peracetic acid in acetone are reported in Table 4. 
Table 4 The conversion and selectivity results of the oxidation of cyclohexene after $1 \mathrm{~h}$. The best catalysts are highlighted in red.

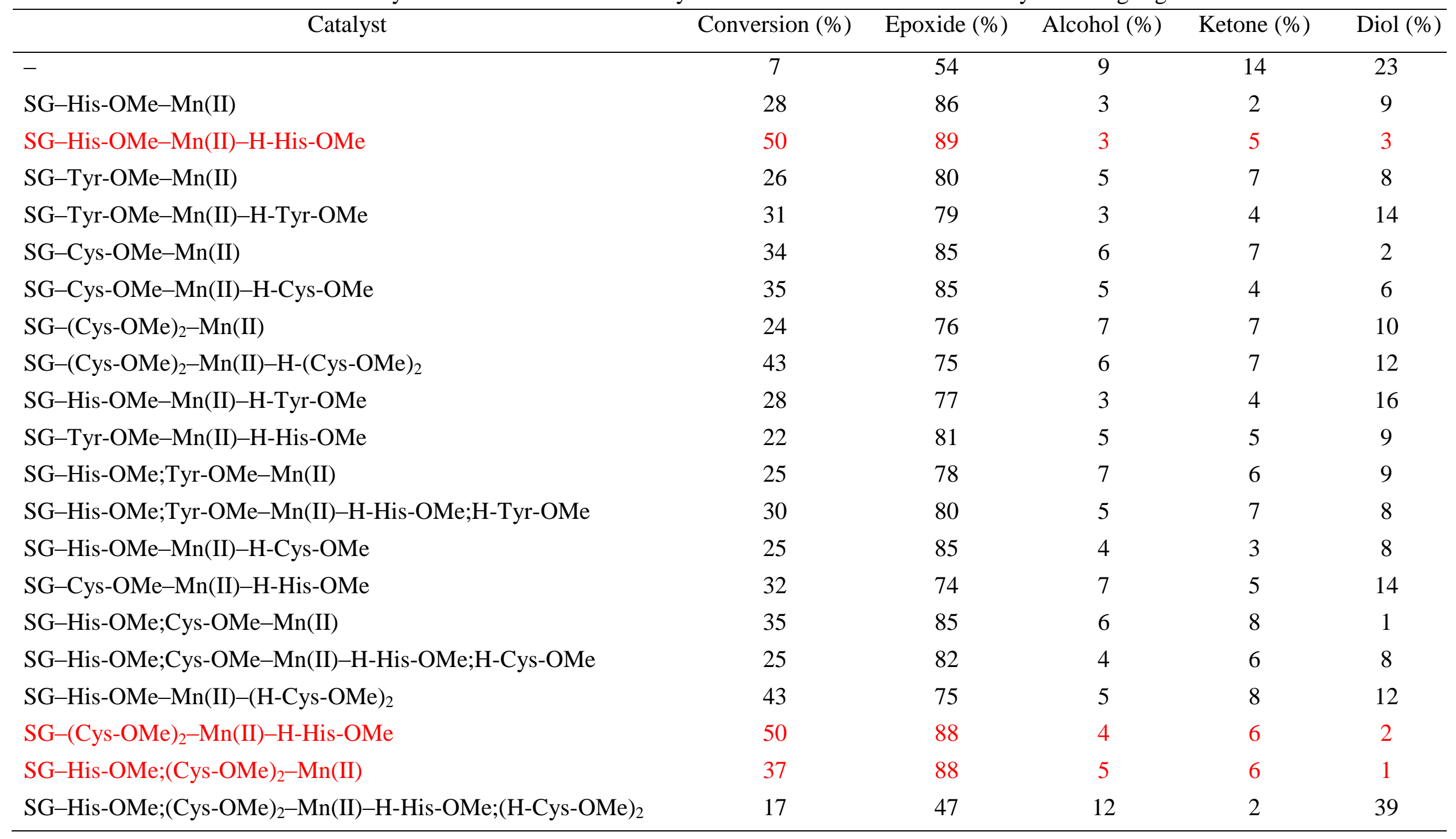


The manganese complexes are probably active in the decomposition of peroxides, i.e., that of the peracetic acid as well. Fortunately, in acetone, the peroxide is protected against decomposition [138]; therefore, acetone was the solvent of choice. This protective property was checked, our immobilised complexes did not promote the decomposition of peracetic acid. Peracetic acid alone (without any catalyst) is a known epoxidation agent. Indeed, epoxidation did occur in our hands as well. The conversion was low; however (Table 4, first entry), in the presence of our immobilised manganese complexes, the transformation of cyclohexene accelerated appreciably; even if conversions over the various immobilised complexes differed significantly. Moreover, the epoxide selectivity also increased considerably relative to the uncatalysed transformation. All the grafted complexes displayed catalytic activity and were selective to cyclohexene oxide formation. The highest activity (50\% conversion) as well as epoxide selectivity (89\%) was reached over SG-His-OMe-Mn(II)-H-His-OMe. There was no leaching of the ligands or the complex either during the reaction. Some of the best catalysts (red ones) were reused two times without significant loss in the catalytic activity and selectivity.

\subsection{Silica-anchored Fe(III) complexes}

\subsubsection{Analytical measurements}

The results of the Kjeldahl method and the ICP-MS measurements for the grafted Fe(III)-complexes containing uniform ligands are displayed in Table 5.

In all cases, the metal ion to amino acid ratios indicate that various kinds of complexes were formed on the surface. The amino acid content of SG-Tyr-OMe$\mathrm{Fe}(\mathrm{III})$ and SG-Tyr-OMe-Fe(III)-H-Tyr-OMe is almost the same, suggesting that the preparation of the ligand-excess complex was not successful. 
Table 5 Amino acid and $\mathrm{Fe}^{3+}$ content of the samples obtained from Kjeldahl type Ndetermination and ICP-MS measurements.

\begin{tabular}{lcc}
\hline Sample & $\begin{array}{c}\text { Amino acid content } \\
(\mathrm{mmol} / \mathrm{g})\end{array}$ & $\begin{array}{c}\mathrm{Fe}^{3+} \text { content } \\
(\mathrm{mmol} / \mathrm{g})\end{array}$ \\
\hline SG-His-OMe-Fe(III) & 0.596 & 0.497 \\
SG-His-OMe-Fe(III)-H-His-OMe & 2.897 & 0.382 \\
SG-Tyr-OMe-Fe(III) & 0.572 & \\
SG-Tyr-OMe-Fe(III)-H-Tyr-OMe & 0.581 & 0.333 \\
SG-Cys-OMe-Fe(III) & 0.460 & \\
SG-Cys-OMe-Fe(III)-H-Cys-OMe & 0.654 & 0.370 \\
SG-(Cys-OMe) $)_{2}-\mathrm{Fe}(\mathrm{III})$ & 0.445 & \\
SG-(Cys-OMe $)_{2}-\mathrm{Fe}(\mathrm{III})-\mathrm{H}-(\mathrm{Cys}-\mathrm{OMe})_{2}$ & 0.924 & \\
\hline
\end{tabular}

\subsubsection{X-ray absorption measurements}

Fe K-edge XAS spectra were recorded for some complexes formed with sulphurcontaining ligands. The XANES spectra of the materials are depicted in Figure 23.

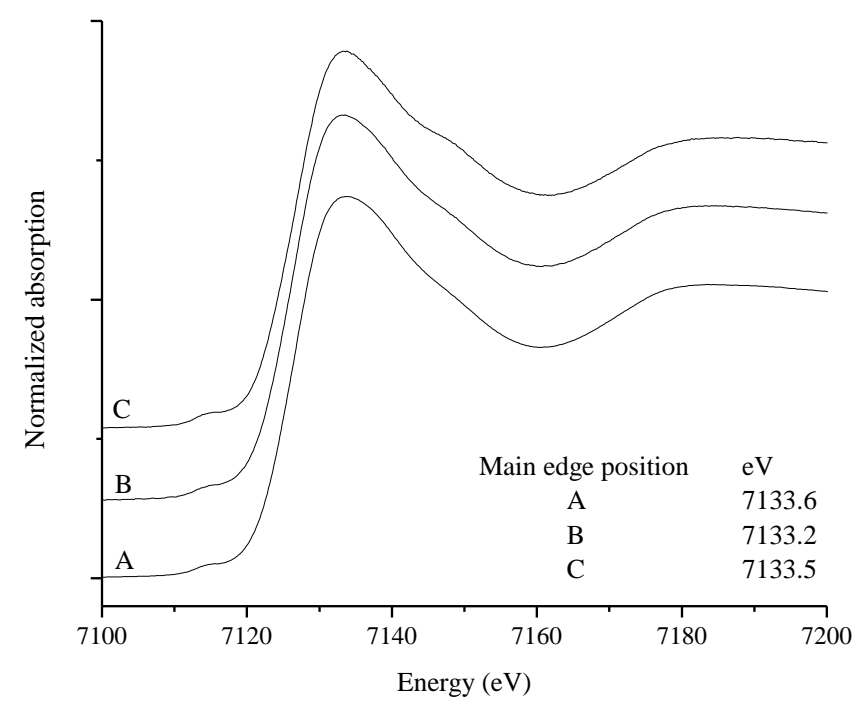

Figure 23 The Fe K-edge XANES spectra of A - SG-(Cys-OMe $)_{2}-\mathrm{Fe}(\mathrm{III})$, B - SG-Cys-OMe-Fe(III), C - SG-His-OMe-Fe(III)-H-Cys-OMe.

Since the local symmetry around Fe is higher in octahedral than in tetrahedral complexes, the intensity of the characteristic pre-edge peak around $7113 \mathrm{eV}$ decreases in the following order: $\mathrm{I}_{\text {tetrahedral }}>\mathrm{I}_{\text {square pyramidal }}>\mathrm{I}_{\text {octahedral }}[139]$. 
Comparison of the normalised intensity of the pre-edge peak in the anchored $\mathrm{Fe}(\mathrm{III})$ complexes $(\mathrm{I} \sim 0.05)$ with that of some reference compounds indicates that the complexes are 5-coordinate; they are square pyramidal [140].

The Fourier-transformed EXAFS data (without phase correction) are displayed in Figure 24, and the results of the fitting are shown in Table 6.

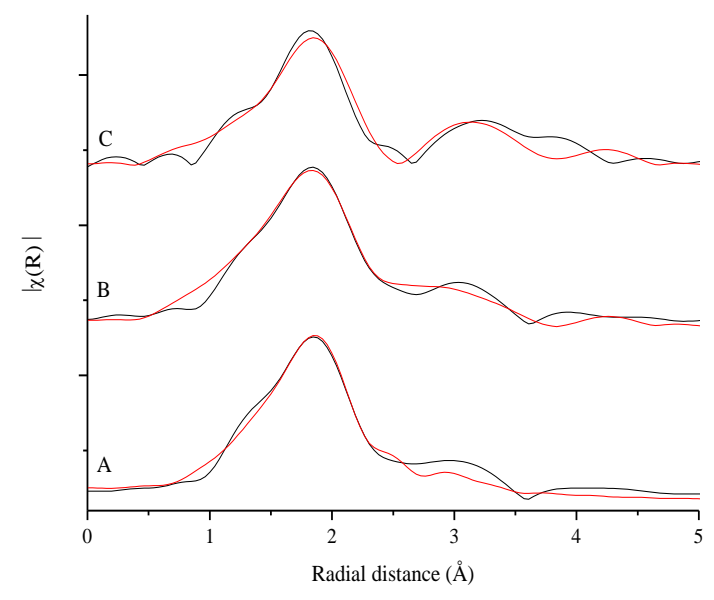

Figure 24 The Fourier-transformed EXAFS data (without phase correction) of A - SG-(Cys-OMe) $)_{2}-\mathrm{Fe}(\mathrm{III}), \mathrm{B}$ - SG-Cys-OMe-Fe(III), C - SG-His-OMe-Fe(III)-HCys-OMe, red line - fit, black line - experimental.

Table 6 Parameters deduced from the fitted EXAFS spectra $(\mathrm{N}$ - coordination number, $\mathrm{R}$ - bond length, $\sigma^{2}$ - Debye-Waller factor, $\Delta \mathrm{E}_{0}$ - energy shift, $\mathrm{R}$ factor - goodness of fit).

\begin{tabular}{lllllll}
\hline Sample & $\left(\mathrm{Fe}^{3+}-\right) \mathrm{X}$ & $\mathrm{N}$ & $\mathrm{R}(\AA)$ & $\sigma^{2}\left(\AA^{2}\right)$ & $\Delta \mathrm{E}_{0}(\mathrm{eV})$ & $\mathrm{R}$ factor \\
\hline SG-(Cys-OMe) $)_{2}-\mathrm{Fe}(\mathrm{III})$ & $\mathrm{O} / \mathrm{N}$ & 5 & 1.98 & 0.0080 & -1.44 & 0.0179 \\
$\mathrm{SG}-\mathrm{Cys}-\mathrm{OMe}-\mathrm{Fe}(\mathrm{III})$ & $\mathrm{O} / \mathrm{N}$ & 4 & 1.98 & 0.0120 & -5.37 & 0.0135 \\
& $\mathrm{~S}$ & 1 & 2.36 & 0.0327 & & \\
& & & & & & \\
SG-His-OMe-Fe(III)-H- & $\mathrm{O} / \mathrm{N}$ & 3.6 & 1.98 & 0.0114 & -5.69 & 0.0120 \\
Cys-OMe & $\mathrm{S}$ & 1.4 & 2.36 & 0.0232 & & \\
\hline
\end{tabular}

In the first coordination shell of $\mathrm{SG}-(\mathrm{Cys}-\mathrm{OMe})_{2}-\mathrm{Fe}(\mathrm{III})$, there are five oxygen/nitrogen atoms, with a Fe(III)-O/N bond length of $1.98 \AA$ A. For SG-Cys-OMe$\mathrm{Fe}(\mathrm{III})$, the first coordination sphere contains four $\mathrm{O} / \mathrm{N}$ atoms and one sulphur atom, where the bond distances were fitted to be 1.98 and $2.36 \AA$, respectively. In SG-His$\mathrm{OMe}-\mathrm{Fe}(\mathrm{III})-\mathrm{H}-\mathrm{Cys}-\mathrm{OMe}$, the $\mathrm{Fe}(\mathrm{III})-\mathrm{O} / \mathrm{N}$ distance is $1.98 \AA$ and the average 
coordination number is 3.6, while for $\mathrm{Fe}(\mathrm{III})-\mathrm{S}$ these date are $2.36 \AA$ and 1.4 , respectively. The thiolate sulphur is coordinated to the $\mathrm{Fe}(\mathrm{III})$ irrespective to whether the cysteine is anchored or non-anchored on the surface of the support.

\subsubsection{FT-IR spectroscopy}

In Figure 25 (trace A), the difference spectrum of SG-His-OMe-Fe(III) is displayed. The $v_{\text {asym(COO-) }}$ and $v_{\text {sym(COO-) }}$ stretching frequencies of the anchored complex are observed at $1630 \mathrm{~cm}^{-1}$ and $1399 \mathrm{~cm}^{-1}$, respectively. $\Delta=231 \mathrm{~cm}^{-1}$, for the ligand it is $170 \mathrm{~cm}^{-1}$. This difference confirms the monodentate nature of the coordinated carboxylate group. The difference spectrum of SG-His-OMe-Fe(III) can be seen in the far IR range in Figure 26, spectrum A. The band at $256 \mathrm{~cm}^{-1}$ indicates that one of the imidazole nitrogen takes part in the complexation. The bands at 352 and $326 \mathrm{~cm}^{-1}$ may be assigned to the $\mathrm{Fe}(\mathrm{III})-\mathrm{O}_{\text {carboxylate }}$ bond. Bidentate binding is quite conceivable under ligand-poor conditions, since there is not enough surface-anchored amino acids in close vicinity to each other for monodentate coordination.

Regarding the mid IR difference spectrum of SG-His-OMe-Fe(III)-H-His-OMe (Figure 25, trace B) it is clear that the surface-anchored complex prepared under ligandpoor conditions rearranged in the presence of excess $\mathrm{C}$-protected histidine. The position of the carbonyl band $\left(1751 \mathrm{~cm}^{-1}\right)$ changed relative to that of the free histidine methylester $\left(1761 \mathrm{~cm}^{-1}\right)$, indicating the coordination of the carbonyl oxygen. The $\mathrm{Fe}(\mathrm{III})-\mathrm{N}_{\text {imidazole }}$ stretching vibration is observed at $265 \mathrm{~cm}^{-1}$ (Figure 26, trace B). The bands above $400 \mathrm{~cm}^{-1}$ can be assigned as coordinated water/ligand vibrations. 


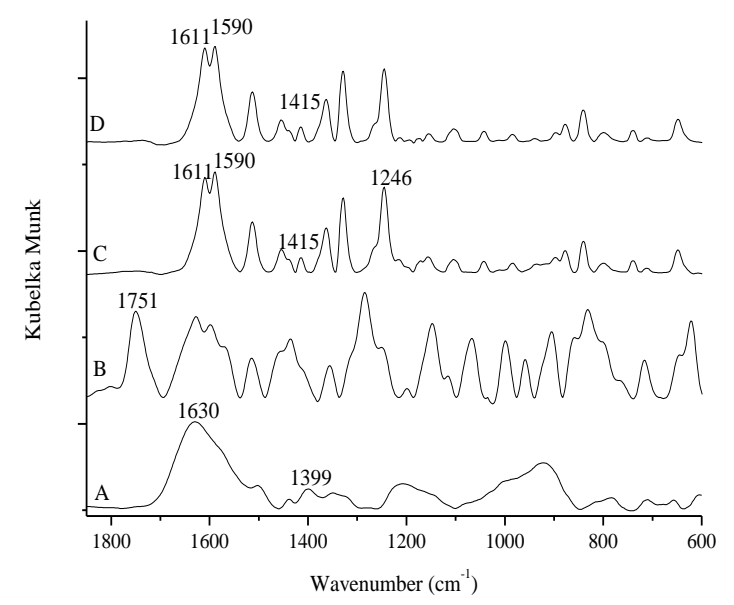

Figure 25 The IR spectra of A - SG-His-OMe-Fe(III), B - SG-His-OMe-Fe(III)-H-His-OMe, C - SG-Tyr-OMe-Fe(III), D - SG-Tyr-OMe-Fe(III)-H-Tyr-OMe.

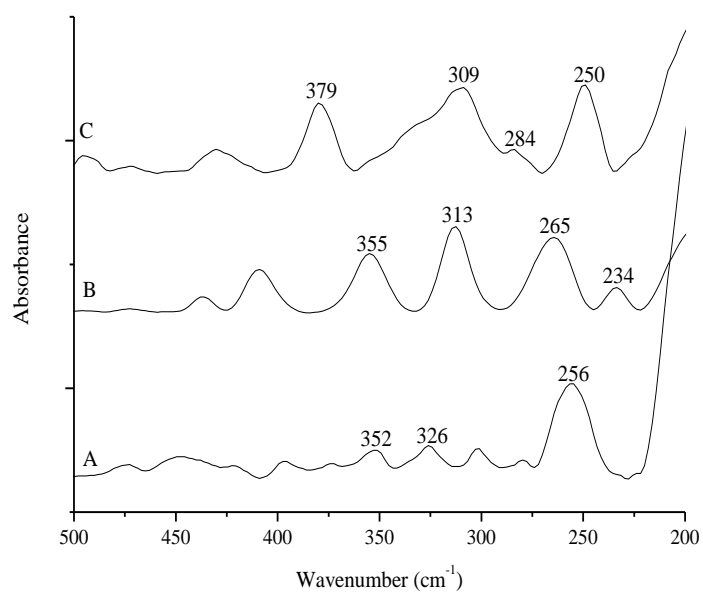

Figure 26 The far IR spectra of A - SG-His-OMe-Fe(III), B - SG-His-OMe-Fe(III)-H-His-OMe, C - SG-Tyr-OMe-Fe(III).

For SG-Tyr-OMe-Fe(III), $\Delta=1611 \mathrm{~cm}^{-1}-1415 \mathrm{~cm}^{-1}=196 \mathrm{~cm}^{-1}$ indicating monodentate coordination of the carboxylate group, since for the ligand this difference is $151 \mathrm{~cm}^{-1}$ (Figure 25, trace $\mathrm{C}$ ). The phenolate oxygen is coordinated to the central ion, since the phenolate $\mathrm{C}-\mathrm{O}^{-}$vibration of the anchored ligand is observed at $1280 \mathrm{~cm}^{-1}$ shifted $1246 \mathrm{~cm}^{-1}$ in the surface-anchored complex. It is easy to observe that the spectra SG-Tyr-OMe-Fe(III) and SG-Tyr-OMe-Fe(III)-H-Tyr-OMe (Figure 25, trace D) are the same. This means that ligand-excess condition did not result the rearrangement of the surface complex, as it was expected from the results provided by the Kjeldahl 
method. In the far IR range (Figure 26, trace C), the bands at 379 and $284 \mathrm{~cm}^{-1}$ reveal that the nitrogen of the secondary amine, which is formed upon covalent grafting, is a coordinating group.

On the basis of the above-listed results and chemical considerations, the following structures for the covalently immobilised complexes may be proposed:

SG-His-OMe-Fe(III)

$\mathrm{N}_{\text {imidazoleHissurf }} \mathrm{O}_{\text {carboxylateHissurf }} \mathrm{H}_{2} \mathrm{O}, \mathrm{H}_{2} \mathrm{O}, \mathrm{H}_{2} \mathrm{O}$,

SG-His-OMe-Fe(III)-H-His-OMe

$\mathrm{N}_{\text {imidazoleHissurf }} \mathrm{O}_{\text {carboxylateHissurf }} \mathrm{O}_{\text {carbonylHis }} \mathrm{N}_{\text {imidazoleHis }} \mathrm{H}_{2} \mathrm{O}$,

SG-Tyr-OMe-Fe(III)

$\mathrm{O}_{\text {carboxylateTyrsurf }} \mathrm{O}_{\text {phenolateTyrsurf }}, \mathrm{N}_{\text {amineTyrsurf }} \mathrm{H}_{2} \mathrm{O}, \mathrm{H}_{2} \mathrm{O}$.

As far as SG-Cys-OMe-Fe(III) is concerned (Figure 27, trace A), the carboxylate group is coordinated as monodentate ligand, since $\Delta$ increased from 190 to $216 \mathrm{~cm}^{-1}$ $\left(1602 \mathrm{~cm}^{-1}-1386 \mathrm{~cm}^{-1}\right)$. The XAS measurement revealed the coordination of the thiolate sulphur, and the lack of the $\mathrm{S}-\mathrm{H}$ vibration further confirms that. Under ligandexcess conditions (Figure 27, trace B) the carbonyl oxygen is not involved in the coordination, since the stretching vibration of the carbonyl band did not shift to lower wavenumbers $\left(1745 \mathrm{~cm}^{-1}\right)$. There is no $\mathrm{S}-\mathrm{H}$ vibration at around $2500 \mathrm{~cm}^{-1}$; therefore, the thiolate sulphur is coordinated.

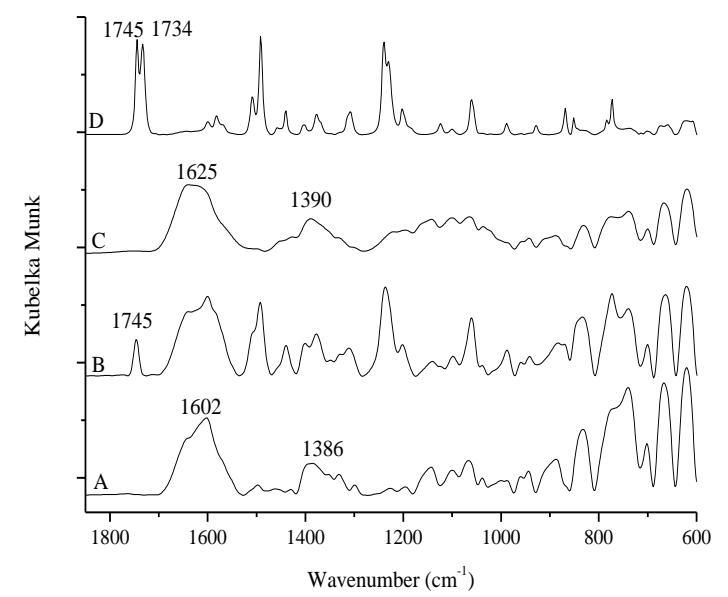

Figure 27 The IR spectra of A - SG-Cys-OMe-Fe(III), B - SG-Cys-OMe-Fe(III)-H-Cys-OMe, C - SG-(Cys-OMe) $)_{2}-\mathrm{Fe}(\mathrm{III})$, $\mathrm{D}-\mathrm{SG}-(\mathrm{Cys}-\mathrm{OMe})_{2}-\mathrm{Fe}(\mathrm{III})-(\mathrm{H}-\mathrm{Cys}-\mathrm{OMe})_{2}$. 


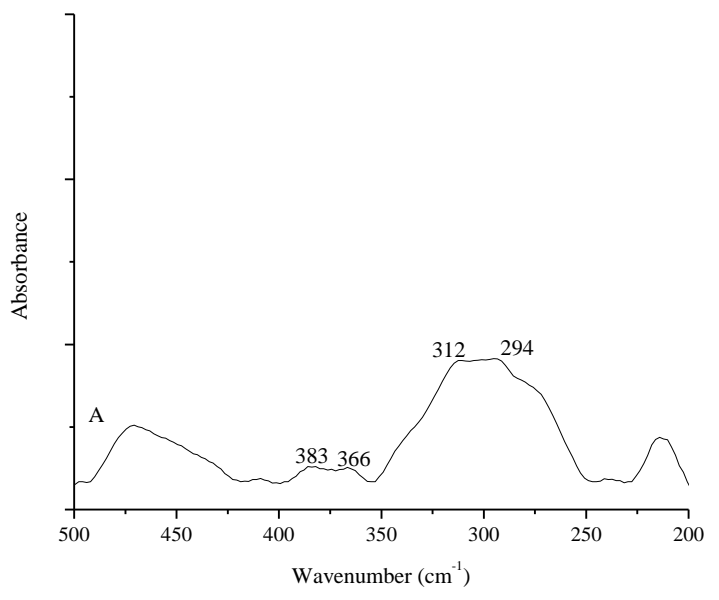

Figure 28 The far IR spectra of A- SG-(Cys-OMe $)_{2}-\mathrm{Fe}(\mathrm{III})-(\mathrm{H}-\mathrm{Cys}-\mathrm{OMe})_{2}$.

For the SG-(Cys-OMe) $)_{2}-\mathrm{Fe}(\mathrm{III}), \Delta=1625 \mathrm{~cm}^{-1}-1390 \mathrm{~cm}^{-1}=235 \mathrm{~cm}^{-1}$ suggesting the monodentate ligation of the carboxylate groups (Figure 27, trace C). Under ligand-excess conditions (Figure 27, trace D), the carbonyl oxygens do not take part in the complexation, since the positions of the bands $\left(1745,1734 \mathrm{~cm}^{-1}\right)$ do not move relative to the pristine amino acid. In the far IR range (Figure 28, trace A) the bands at 383 and $294 \mathrm{~cm}^{-1}$ correspond to the $\mathrm{Fe}(\mathrm{III})-\mathrm{N}_{\text {amino }}$ vibrations.

Using all these pieces of information structural proposals for the surface-bound complexes are offered as follows:

SG-Cys-OMe-Fe(III)

$\mathrm{S}_{\text {thiolateCyssurf }} \mathrm{O}_{\text {carboxylateCyssurf }} \mathrm{H}_{2} \mathrm{O}, \mathrm{H}_{2} \mathrm{O}, \mathrm{H}_{2} \mathrm{O}$,

SG-Cys-OMe-Fe(III)-H-Cys-OMe

$\mathrm{S}_{\text {thiolateCyssurf }} \mathrm{O}_{\text {carboxylateCysssurf }} \mathrm{S}_{\text {thiolateCys }} \mathrm{S}_{\text {thiolateCys }} \mathrm{H}_{2} \mathrm{O}$,

SG-(Cys-OMe $)_{2}-\mathrm{Fe}(\mathrm{III})$

$\mathrm{O}_{\text {carboxylate(Cys)2surf }} \mathrm{O}_{\text {carboxylate(Cys)2surf }} \mathrm{H}_{2} \mathrm{O}, \mathrm{H}_{2} \mathrm{O}, \mathrm{H}_{2} \mathrm{O}$,

SG-(Cys-OMe $)_{2}-\mathrm{Fe}(\mathrm{III})-(\mathrm{H}-\mathrm{Cys}-\mathrm{OMe})_{2}$

$\mathrm{O}_{\text {carboxylate(Cys)2surf }} \mathrm{O}_{\text {carboxylate(Cys)2surf }} \mathrm{N}_{\text {amino(Cys)2 }} \mathrm{N}_{\text {amino(Cys) } 2} \mathrm{H}_{2} \mathrm{O}$.

Figure 29, trace A depicts the difference spectrum of SG-His-OMe-Fe(III)-HTyr-OMe. The structure of SG-His-OMe-Fe(III) was determined above. It is clear that the addition of C-protected tyrosine rearranged the surface complex. The stretching vibration of the carbonyl band shifted to $1687 \mathrm{~cm}^{-1}$ from $1745 \mathrm{~cm}^{-1}$, indicating that the carbonyl oxygen appeared in the coordination sphere of the metal ion. 
For SG-(Tyr-OMe)-Fe(III)-(H-His-OMe) (Figure 29, trace B), the carbonyl oxygen of C-protected histidine took part in the complexation, since the position of the carbonyl band, which was found to be at $1761 \mathrm{~cm}^{-1}$ in the spectrum of the free histidine methylester, moved to $1743 \mathrm{~cm}^{-1}$.

Studying the mid IR difference spectra of SG-(His-OMe,Tyr-OMe)-Fe(III) (Figure 29, trace C), reveals that the carboxylate vibrations of amino acids cannot be separated, but one may assume that the coordination modes of the amino acid are the same as in the complexes with uniform amino acids as ligands.

As far as the spectrum of the anchored complex prepared under ligand-excess conditions is concerned (Figure 29, trace D), similarity with spectrum of the neat Cprotected histidine can be observed: the carbonyl band did not shift. There are no characteristic peaks of $\mathrm{C}$-protected tyrosine, indicating that from the added 1:1 molar mixture of the amino acids only the histidine methylester takes part in the complexation via the imidazole nitrogen.

The above-detailed observations may be concluded in the following coordination environments:

SG-His-OMe-Fe(III)-H-Tyr-OMe

$$
\mathrm{N}_{\text {imidazoleHissurf }} \mathrm{O}_{\text {carboxylateHissurf }} \mathrm{O}_{\text {carbonylTyr }} \mathrm{N}_{\text {aminoTyr }} \mathrm{H}_{2} \mathrm{O} \text {, }
$$

SG-Tyr-OMe-Fe(III)-H-His-OMe

$$
\mathrm{O}_{\text {carboxylateTyrsurf }} \mathrm{N}_{\text {amineTyrsurf }} \mathrm{O}_{\text {phenolateTyrsurf }} \mathrm{N}_{\text {imidazoleHis }} \mathrm{O}_{\text {carbonylHis, }}
$$

SG-His-OMe;Tyr-OMe-Fe(III)

$$
\mathrm{N}_{\text {imidazoleHissurf }} \mathrm{O}_{\text {carboxylateHissurf }} \mathrm{N}_{\text {amineTyrsurf }} \mathrm{O}_{\text {phenolateTyrsurf }} \mathrm{O}_{\text {carboxylateTyrsurf }} \text {, }
$$

SG-His-OMe;Tyr-OMe-Fe(III)-H-His-OMe;H-Tyr-OMe

$\mathrm{N}_{\text {imidazoleHissurf }} \mathrm{O}_{\text {carboxylateHissurf }} \mathrm{O}_{\text {carboxylateTyrsurf }} \mathrm{O}_{\text {phenolateTyrsurf }} \mathrm{N}_{\text {imidazoleHis }}$. 


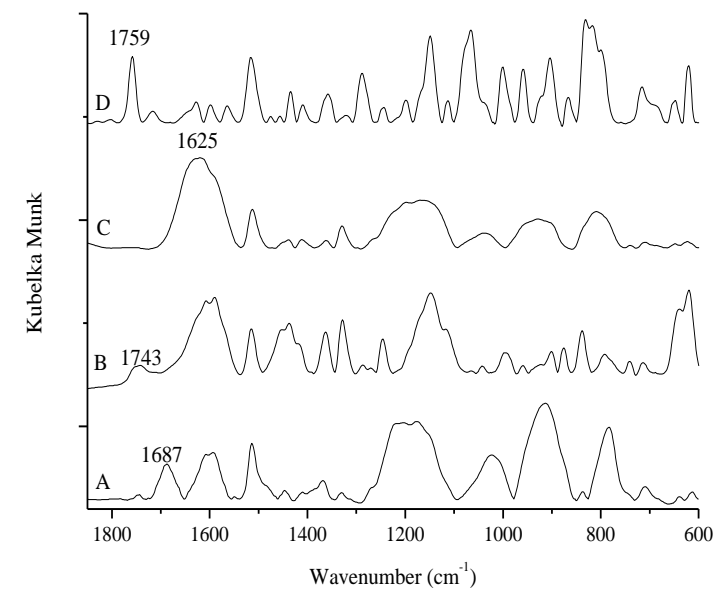

Figure 29 The IR spectra of A - SG-His-OMe-Fe(III)-H-Tyr-OMe, B - SG-Tyr-OMe-Fe(III)-H-His-OMe, C - SG-His-OMe;Tyr-OMe-Fe(III), D - SG-His-OMe;Tyr-OMe-Fe(III)-H-His-OMe;H-Tyr-OMe.

The spectrum of SG-His-OMe-Fe(III)-H-Cys-OMe (Figure 30, trace A) is very similar to that of the pristine cysteine methylester, while spectrum B resembles that of the unanchored histidine methylester (SG-Cys-OMe-Fe(III)-H-His-OMe). This means that the added amino acid ester rearranged the complex formed upon soaking the silica gel, containing the covalently bonded (other) amino acid in the Fe(III) salt solution. Analysis of the spectra reveals that the carbonyl oxygen of the added C-protected amino is not coordinated, since the position of the carbonyl band hardly changed relative to that of the free amino acid methylester. The absence of the $\mathrm{S}-\mathrm{H}$ vibration confirms that the thiolate sulphur participates in the complexation, as it was learnt from EXAFS measurements.

As far as SG-His-OMe;Cys-OMe-Fe(III) is concerned (Figure 30, trace C), the amino acids are proposed to coordinate the same way, when they were used separately, since their vibrations cannot be separated. Spectrum D indicates that histidine methylester is only coordinated from the 1:1 H-His-OMe, H-Cys-OMe mixture added in excess. It can also be learnt that its carbonyl oxygen is not a coordinating site, since its position did not shift on adding the mixture to the material prepared under ligand-poor conditions.

The proposed coordination modes are the followings:

SG-His-OMe-Fe(III)-H-Cys-OMe

$\mathrm{N}_{\text {imidazoleHissurf }} \mathrm{O}_{\text {carboxylateHissurf }} \mathrm{S}_{\text {thiolateCys }} \mathrm{S}_{\text {thiolateCys }} \mathrm{H}_{2} \mathrm{O}$, 
SG-Cys-OMe-Fe(III)-H-His-OMe

$\mathrm{S}_{\text {thiolateCyssurf }} \mathrm{O}_{\text {carboxylateCysssurf }} \mathrm{N}_{\text {imidazoleHis }} \mathrm{N}_{\text {imidazoleHis }} \mathrm{H}_{2} \mathrm{O}$,

SG-His-OMe;Cys-OMe-Fe(III)

$\mathrm{N}_{\text {imidazoleHissurf }} \mathrm{O}_{\text {carboxylateHissurf }} \mathrm{S}_{\text {thiolateCyssurf }} \mathrm{O}_{\text {carboxylateCysssurf }} \mathrm{H}_{2} \mathrm{O}$,

SG-His-OMe;Cys-OMe-Fe(III)-H-His-OMe;H-Cys-OMe

$\mathrm{N}_{\text {imidazoleHissurf }} \mathrm{O}_{\text {carboxylateHissurf }} \mathrm{S}_{\text {thiolateCyssurf }} \mathrm{O}_{\text {carboxylateCysssurf }} \mathrm{N}_{\text {imidazoleHis }}$.

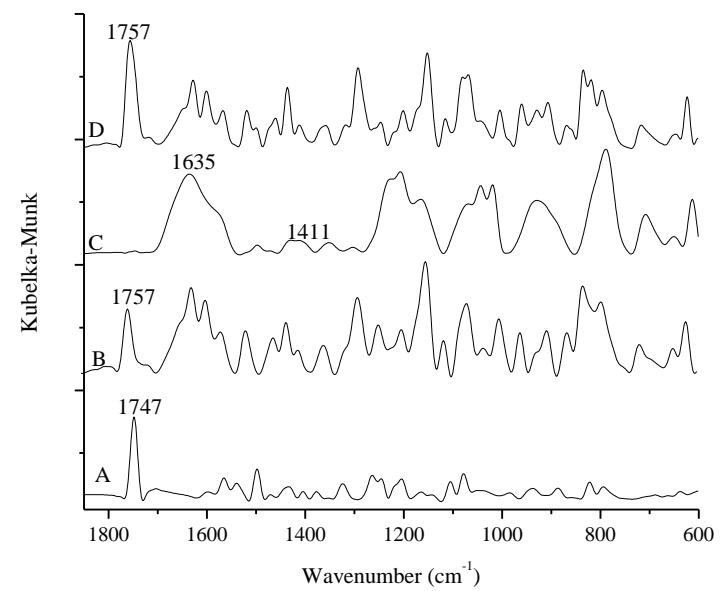

Figure 30 The IR spectra of A - SG-His-OMe-Fe(III)-H-Cys-OMe, B - SG-Cys-OMe-Fe(III)-H-His-OMe, C - SG-His-OMe;Cys-OMe-Fe(III), D - SG-His-OMe;Cys-OMe-Fe(III)-H-His-OMe;H-Cys-OMe.

SG-His-OMe-Fe(III) was rearranged by adding C-protected cystine in excess (Figure 31, trace A). The stretching vibration of the carbonyl bands $\left(1739 \mathrm{~cm}^{-1}\right)$ did not move relative to the free $\mathrm{C}$-protected cysteine; therefore, it can only coordinate with the amino nitrogens.

In Figure 31, trace B depicts the spectrum of SG-(Cys-OMe $)_{2}-\mathrm{Fe}(\mathrm{III})-\mathrm{H}-\mathrm{His}-$ OMe. The spectrum is very similar to that of the C-protected histidine - the carbonyl oxygen does not participate in the complexation.

In SG-His-OMe;(Cys-OMe) $)_{2}-\mathrm{Fe}(\mathrm{III})$, the anchored amino acids are again assumed to coordinate as they did alone. (Figure 31, trace C).

Under ligand-excess conditions (Figure 31, trace D), three unshifted carbonyl vibrations can be seen at 1760 (C-protected histidine), 1746 and $1734 \mathrm{~cm}^{-1}$ (C-protected cystine). Unfortunately, their far IR spectra are unusable, but on the basis of these observations and the accumulated knowledge described at the complexes formed with uniform ligands, the following structures may be proposed: 
SG-His-OMe-Fe(III)-(H-Cys-OMe $)_{2}$

$\mathrm{N}_{\text {imidazoleHissurf }} \mathrm{O}_{\text {carboxylateHissurf }} \mathrm{N}_{\text {amino(Cys) } 2} \mathrm{~N}_{\text {amino(Cys)2 }} \mathrm{H}_{2} \mathrm{O}$,

SG-(Cys-OMe $)_{2}-\mathrm{Fe}(\mathrm{III})-\mathrm{H}-\mathrm{His}-\mathrm{OMe}$

$\mathrm{O}_{\text {carboxylate(Cys)2surf }} \mathrm{O}_{\text {carboxylate(Cys)2surf }} \mathrm{N}_{\text {imidazoleHis }} \mathrm{N}_{\text {imidazoleHis }} \mathrm{H}_{2} \mathrm{O}$,

SG-His-OMe;(Cys-OMe) $)_{2}-\mathrm{Fe}(\mathrm{III})$

$\mathrm{N}_{\text {imidazoleHissurf }} \mathrm{O}_{\text {carboxylateHissurf }} \mathrm{O}_{\text {carboxylate(Cys)2surf }} \mathrm{O}_{\text {carboxylate(Cys)2surf }} \mathrm{H}_{2} \mathrm{O}$,

SG-His-OMe;(Cys-OMe $)_{2}-\mathrm{Fe}(\mathrm{III})-\mathrm{H}-\mathrm{His}-\mathrm{OMe} ;(\mathrm{H}-\mathrm{Cys}-\mathrm{OMe})_{2}$

$\mathrm{N}_{\text {imidazoleHissurf }} \mathrm{O}_{\text {carboxylateHissurf }} \mathrm{O}_{\text {carboxylate(Cys)2surf }} \mathrm{N}_{\text {imidazoleHis }} \mathrm{N}_{\text {amino(Cys)2 }}$.

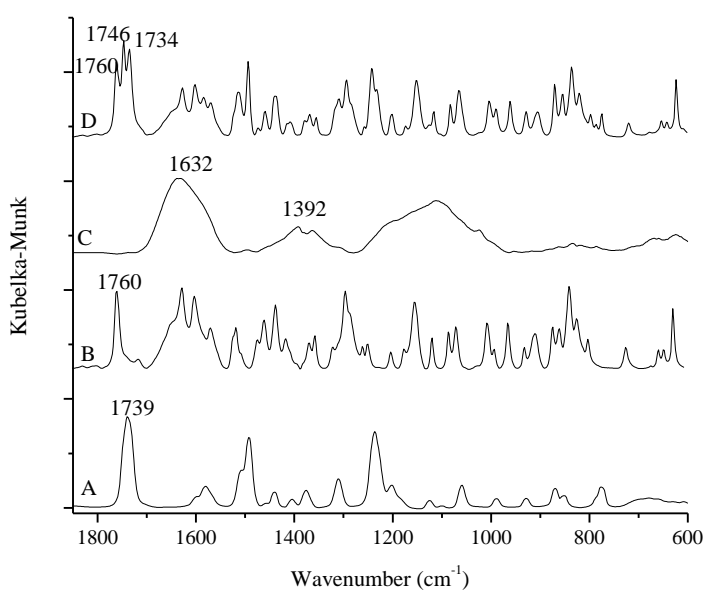

Figure 31 The IR spectra of A - SG-His-OMe-Fe(III)-(H-Cys-OMe $)_{2}$, B - SG-(Cys-OMe $)_{2}-\mathrm{Fe}(\mathrm{III})-\mathrm{H}-\mathrm{His}-\mathrm{OMe}, \mathrm{C}-\mathrm{SG}-\mathrm{His}-\mathrm{OMe}$;(Cys-OMe $)_{2}-\mathrm{Fe}(\mathrm{III})$, $\mathrm{D}$ - SG-His-OMe;(Cys-OMe $)_{2}-\mathrm{Fe}(\mathrm{III})-\mathrm{H}-\mathrm{His}-\mathrm{OMe} ;(\mathrm{H}-\mathrm{Cys}-\mathrm{OMe})_{2}$.

\subsubsection{Testing the superoxide dismutase activity}

All materials were active in catalysing the dismutation reaction of the superoxide radical anion. Catalytic activities differed widely though (Table 7).

Data reveal that there were catalysts with activity close to that of the $\mathrm{Cu}, \mathrm{ZnSOD}$ enzyme. The most active substances contain cysteine indicating the key role of cysteinelike structures in determining catalytic activity. They seem to have the optimum structures for promoting this reaction. SG-Tyr-OMe-Fe(III) was the second most active material, in which tyrosine coordinates as tridentate ligand, making the complex more strained. 
Table 7 The SOD activities of the surface grafted complexes. The best catalysts are highlighted in red.

\begin{tabular}{|c|c|}
\hline Materials & $\mathrm{IC}_{50}(\mu \mathrm{M})$ \\
\hline Cu,ZnSOD enzyme & 0.4 \\
\hline SG-His-OMe-Fe(III) & 57 \\
\hline SG-His-OMe-Fe(III)-H-His-OMe & 47 \\
\hline SG-Tyr-OMe-Fe(III) & 5 \\
\hline SG-Cys-OMe-Fe(III) & 6 \\
\hline SG-Cys-OMe-Fe(III)-H-Cys-OMe & 31 \\
\hline $\mathrm{SG}-(\mathrm{Cys}-\mathrm{OMe})_{2}-\mathrm{Fe}(\mathrm{III})$ & 36 \\
\hline $\mathrm{SG}-(\mathrm{Cys}-\mathrm{OMe})_{2}-\mathrm{Fe}(\mathrm{III})-\mathrm{H}-(\mathrm{Cys}-\mathrm{OMe})_{2}$ & 33 \\
\hline SG-His-OMe-M-Fe(III)-Tyr-OMe & 132 \\
\hline SG-Tyr-OMe-Fe(III)-H-His-OMe & 30 \\
\hline SG-His-OMe;Tyr-OMe-Fe(III) & 34 \\
\hline SG-His-OMe;Tyr-OMe-Fe(III)-H-His-OMe;H-Tyr-OMe & 78 \\
\hline SG-His-OMe-Fe(III)-H-Cys-OMe & 28 \\
\hline SG-Cys-OMe-Fe(III)-H-His-OMe & 25 \\
\hline SG-His-OMe;Cys-OMe-Fe(III) & 21 \\
\hline SG-His-OMe;Cys-OMe-Fe(III)-H-His-OMe;H-Cys-OMe & 4 \\
\hline SG-His-OMe-Fe(III)-(H-Cys-OMe $)_{2}$ & 24 \\
\hline $\mathrm{SG}-(\mathrm{Cys}-\mathrm{OMe})_{2}-\mathrm{Fe}(\mathrm{III})-\mathrm{H}-\mathrm{His}-\mathrm{OMe}$ & 32 \\
\hline SG-His-OMe;(Cys-OMe) $)_{2}-\mathrm{Fe}(\mathrm{III})$ & 31 \\
\hline SG-His-OMe; $(\text { Cys-OMe })_{2}-\mathrm{Fe}(\mathrm{III})-\mathrm{H}-\mathrm{His}-\mathrm{OMe} ;(\mathrm{H}-\mathrm{Cys}-\mathrm{OMe})_{2}$ & 28 \\
\hline
\end{tabular}

\subsubsection{Catalytic oxidation of cyclohexene}

The conversion and selectivity results of the immobilised catalysts on the oxidation of cyclohexene with peracetic acid in acetone are reported in Table 8 . 
Table 8 The conversion and selectivity results of the oxidation of cyclohexene after $3 \mathrm{~h}$. The best catalysts are highlighted in red.

\begin{tabular}{|c|c|c|c|c|c|}
\hline Catalyst & Conversion $(\%)$ & Epoxide (\%) & Alcohol (\%) & Ketone $(\%)$ & Diol (\%) \\
\hline- & 21 & 64 & 4 & 2 & 30 \\
\hline SG-His-OMe-Fe(III) & 47 & 89 & 1 & 3 & 7 \\
\hline SG-Tyr-OMe-Fe(III) & 45 & 94 & 2 & 1 & 3 \\
\hline SG-Cys-OMe-Fe(III) & 59 & 87 & 3 & 8 & 2 \\
\hline SG-Cys-OMe-Fe(III)-H-Cys-OMe & 56 & 99 & 1 & 0 & 0 \\
\hline $\mathrm{SG}-(\mathrm{Cys}-\mathrm{OMe})_{2}-\mathrm{Fe}(\mathrm{III})$ & 25 & 97 & 1 & 1 & 1 \\
\hline $\mathrm{SG}-(\mathrm{Cys}-\mathrm{OMe})_{2}-\mathrm{Fe}(\mathrm{III})-\mathrm{H}-(\mathrm{Cys}-\mathrm{OMe})_{2}$ & 10 & 95 & 2 & 1 & 2 \\
\hline SG-His-OMe-Fe(III)-H-Cys-OMe & 44 & 88 & 2 & 0 & 10 \\
\hline SG-Cys-OMe-Fe(III)-H-His-OMe & 65 & 85 & 2 & 9 & 4 \\
\hline SG-His-OMe;Cys-OMe-Fe(III) & 49 & 98 & 1 & 0 & 1 \\
\hline SG-His-OMe;Cys-OMe-Fe(III)-H-His-OMe;H-Cys-OMe & 32 & 97 & 1 & 1 & 1 \\
\hline
\end{tabular}


For the supported $\mathrm{Fe}(\mathrm{III})$ complexes $3 \mathrm{~h}$ reaction time and $2.5 \mathrm{mmol}$ peracetic acid were needed to obtain the highest epoxide selectivity. All the chosen immobilised complexes were catalytically active, and the major product of the reactions was the epoxide. SG-Cys-OMe-Fe(III)-H-Cys-OMe was the most selective (99\%) and the most active (56\% conversion) catalyst. In general cystine containing materials did not catalyse this reaction well, moreover, for $\mathrm{SG}-(\mathrm{Cys}-\mathrm{OMe})_{2}-\mathrm{Fe}(\mathrm{III})-\mathrm{H}-(\mathrm{Cys}-\mathrm{OMe})_{2}$ the observed conversion was lower than that of the homogeneous, uncatalysed reaction. Significant leaching of the catalyst was not observed, and the catalysts, highlighted in red in Table 8, could be reused twice.

\subsection{Silica-anchored Co(II) complexes}

\subsubsection{X-ray absorption measurements}

Co K-edge XANES spectra of some grafted Co(II) complexes are shown in Figure 32.

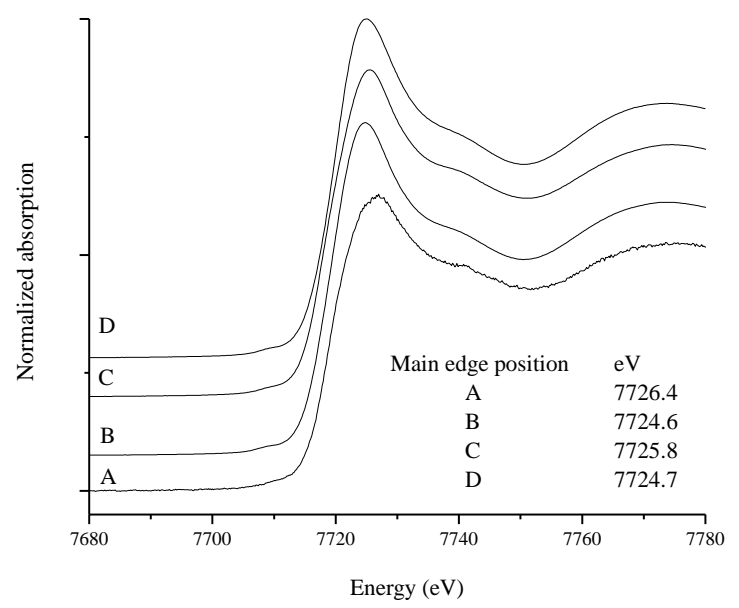

Figure 32 Co K-edge XANES spectra of A - SG-His-OMe-Co(II), $\mathrm{B}$ - SG-Cys-OMe-Co(II), C - SG-(Cys-OMe $)_{2}-\mathrm{Co}(\mathrm{II})$, D - SG-His-OMe-Co(II)-H-Cys-OMe immobilised complexes.

The $1 \mathrm{~s} \rightarrow 3 \mathrm{~d}$ pre-edge peak in the Co spectra around $7710 \mathrm{eV}$ is also sensitive to the symmetry and geometry of the complexes. The relatively small intensity indicates that the cobalt centres are centrosymmetric: octahedral or square planar. In a squareplanar arrangement, a large shoulder appears at $7715 \mathrm{eV}$, which is due to the $1 \mathrm{~s} \rightarrow 4 \mathrm{p}_{z}$ transition. An intense pre-edge peak suggests the loss of centrosymmetry, resulting from 
the formation of a five-coordinate complex [141]. The XANES spectra of the immobilised $\mathrm{Co}$ (II) complexes reveals that all of them are octahedral. The position of the main edge is at lower energies for SG-Cys-OMe-Co(II) and SG-His-OMe-Co(II)$\mathrm{H}$-Cys-OMe that may indicate the coordination of the sulphur atom of the thiolate group.

The Fourier-transformed EXAFS data (without phase correction) are displayed in Figure 33, and the results of the fitting are reported in Table 9.

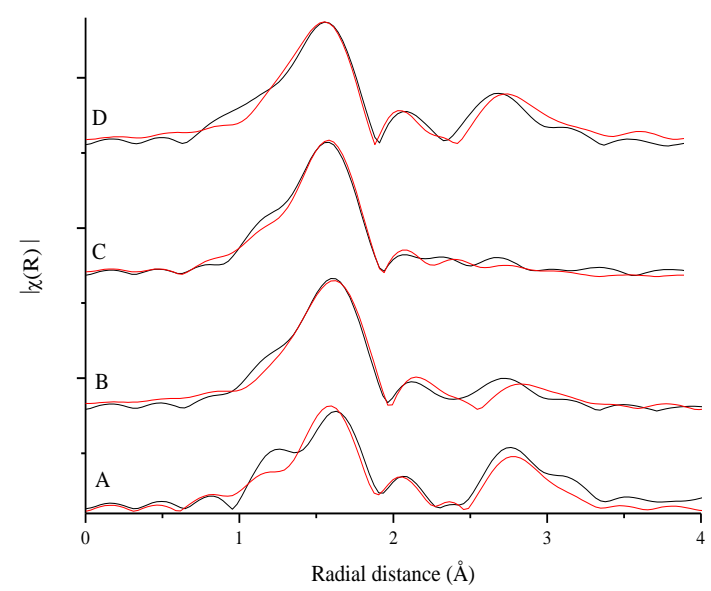

Figure 33 The Fourier-transformed EXAFS data (without phase correction) of A - SG-His-OMe-Co(II), B - SG-Cys-OMe-Co(II), C - SG-(Cys-OMe) ${ }_{2}-\mathrm{Co}(\mathrm{II})$, D - SG-His-OMe-Co(II)-H-Cys-OMe, red line - fitted, black line - experimental.

Table 9 Parameters deduced from the fitted EXAFS spectra $(\mathrm{N}$ - coordination number, $\mathrm{R}$ - bond length, $\sigma^{2}$ - Debye-Waller factor, $\Delta \mathrm{E}_{0}$ - energy shift, $\mathrm{R}$ factor - goodness of fit).

\begin{tabular}{lllllll}
\hline Sample & $\left(\mathrm{Co}^{2+}-\right) \mathrm{X}$ & $\mathrm{N}$ & $\mathrm{R}(\AA)$ & $\sigma^{2}\left(\AA^{2}\right)$ & $\Delta \mathrm{E}_{0}(\mathrm{eV})$ & $\mathrm{R}$ factor \\
\hline SG-His-OMe-Co(II) & $\mathrm{O} / \mathrm{N}$ & 6 & 2.05 & 0.0043 & -1.00 & 0.0494 \\
SG-Cys-OMe-Co(II) & $\mathrm{O} / \mathrm{N}$ & 4.8 & 2.08 & 0.0086 & 1.63 & 0.0241 \\
& $\mathrm{~S}$ & 1.2 & 2.61 & 0.0195 & & \\
& & & & & & \\
SG-(Cys-OMe) ${ }_{2}-\mathrm{Co}(\mathrm{II})$ & $\mathrm{O} / \mathrm{N}$ & 6 & 2.08 & 0.0069 & -0.26 & 0.0093 \\
SG-His-OMe-Co(II)-H- & $\mathrm{O} / \mathrm{N}$ & 4.7 & 2.04 & 0.0089 & 1.84 & 0.0191 \\
Cys-OMe & $\mathrm{S}$ & 1.3 & 2.57 & 0.0217 & & \\
\hline
\end{tabular}

The EXAFS measurements showed that six oxygen/nitrogen atoms were coordinated to the $\mathrm{Co}(\mathrm{II})$ ion in SG-His-OMe-Co(II) and SG-(Cys-OMe) $)_{2}-\mathrm{Co}(\mathrm{II})$, 
where the $\mathrm{Co}(\mathrm{II})-\mathrm{O} / \mathrm{N}$ bond lengths were fitted to be $2.05 \AA$ and $2.08 \AA$, respectively. For SG-Cys-OMe-Co(II) and SG-His-OMe-Co(II)-H-Cys-OMe the first coordination shell contains oxygen/nitrogen atoms and sulphur atoms as well. The $\mathrm{Co}(\mathrm{II})-\mathrm{O} / \mathrm{N}$ distances are $2.08 \AA$ and $2.04 \AA$, while the $\mathrm{Co}(\mathrm{II})-\mathrm{S}$ distances are $2.61 \AA$ and $2.57 \AA$, respectively. We can conclude that the sulphur atom of cysteine is in the coordination sphere of the Co(II) ion when the amino acid is covalently grafted and when it is nonanchored to the surface of the support as well.

\subsubsection{FT-IR spectroscopy}

Analysis of the spectrum of SG-His-OMe-Co(II) reveals that under ligand-poor conditions (Figure 34, trace A), the carboxylate group is coordinated to the centre ion as monodentate ligand, since $\Delta$ increased from $170 \mathrm{~cm}^{-1}$ to $212 \mathrm{~cm}^{-1}$. In the far IR range the vibration at $256 \mathrm{~cm}^{-1}$ corresponds to the $\mathrm{Co}(\mathrm{II})-\mathrm{N}_{\text {imidazole }}$ bond (Fig. 35).

The added histidine methylester (Figure 34, trace B) changes the spectrum of the former complex. This means that ligand excess results in the rearrangement of the surface complex. The carbonyl oxygen of the added histidine methylester does not take part in complexation, the position of its vibration $\left(1760 \mathrm{~cm}^{-1}\right)$ is close to that of the pristine ester. It is very probable that the coordination occurs via the imidazole nitrogen.

The spectra of SG-Tyr-OMe-Co(II) and SG-Tyr-OMe-Co(II)-H-Tyr-OMe are very similar to each other, indicating that the added C-protected tyrosine is not coordinated. $\Delta=161 \mathrm{~cm}^{-1}$, which suggests monodentate coordination mode for the carboxylate group. The phenolate $\mathrm{C}-\mathrm{O}^{-}$vibration shifted to $1260 \mathrm{~cm}^{-1}$ upon complexation. 


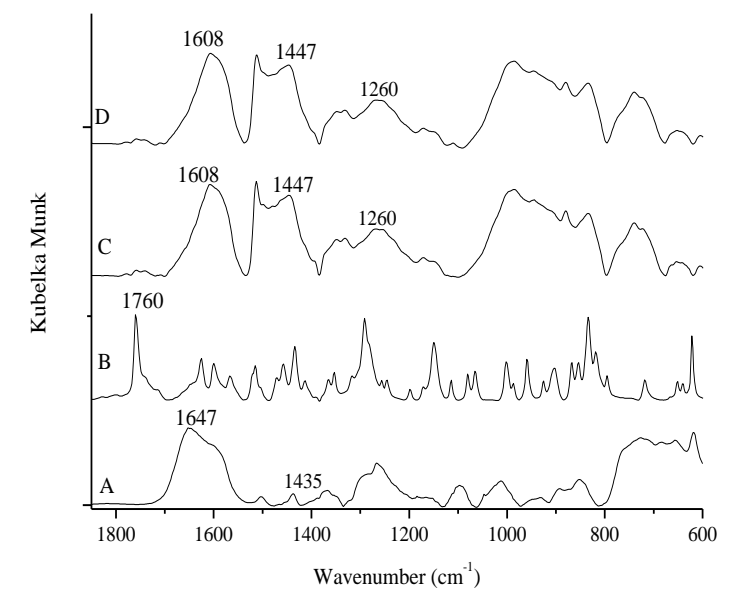

Figure 34 The IR spectra of A - SG-His-OMe-Co(II), B - SG-His-OMe-Co(II)-H-His-OMe, C - SG-Tyr-OMe-Co(II), D - SG-Tyr-OMe-Co(II)-H-Tyr-OMe.

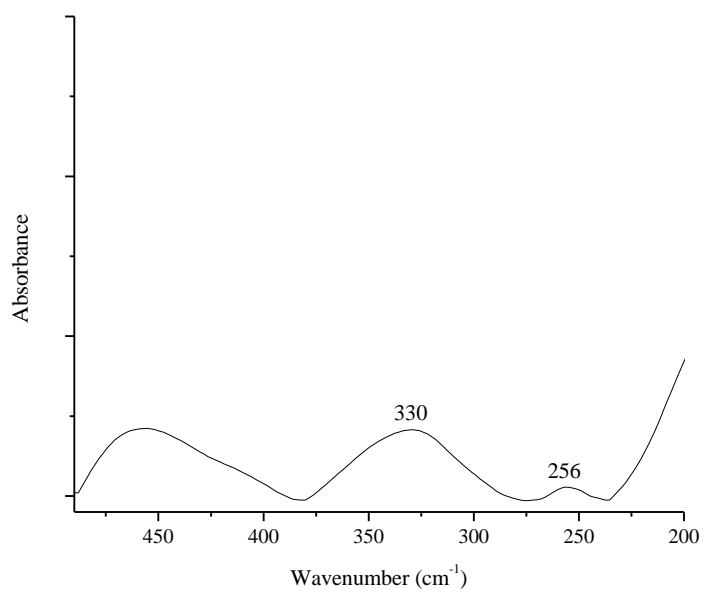

Figure 35 The far IR spectrum of SG-His-OMe-Co(II).

On the basis of the above results and chemical considerations, structural proposals for the surface-bound complexes are offered as follows:

\section{SG-His-OMe-Co(II)}

$\mathrm{N}_{\text {imidazoleHissurf }} \mathrm{O}_{\text {carboxylateHissurf }} \mathrm{H}_{2} \mathrm{O}, \mathrm{H}_{2} \mathrm{O}, \mathrm{H}_{2} \mathrm{O}, \mathrm{H}_{2} \mathrm{O}$,

SG-His-OMe-Co(II)-H-His-OMe

$\mathrm{N}_{\text {imidazoleHissurf }} \mathrm{O}_{\text {carboxylateHissurf }} \mathrm{N}_{\text {imidazoleHis }}, \mathrm{N}_{\text {imidazoleHis }} \mathrm{H}_{2} \mathrm{O}, \mathrm{H}_{2} \mathrm{O}$,

SG-Tyr-OMe-Co(II)

$\mathrm{O}_{\text {carboxylateTyrsurf }} \mathrm{O}_{\text {phenolateTyrsurf }}, \mathrm{H}_{2} \mathrm{O}, \mathrm{H}_{2} \mathrm{O}, \mathrm{H}_{2} \mathrm{O}, \mathrm{H}_{2} \mathrm{O}$. 
In the spectrum of SG-Cys-OMe-Co(II) (Figure 36, trace A), $\Delta$ slightly increased (from $190 \mathrm{~cm}^{-1}$ to $200 \mathrm{~cm}^{-1}$ ), indicating that the carboxylate group was coordinated to the metal ion as monodentate ligand. There is no $\mathrm{S}-\mathrm{H}$ vibration around $2500 \mathrm{~cm}^{-1}$; thus, the thiolate sulphur takes part in the complexation. As far as SG-Cys-OMe-Co(II)-HCys-OMe is concerned (Figure 36, trace B), the ligand-poor complex rearranged, the added C-protected cysteine coordinated via its sulphur atom, the carbonyl oxygen was not coordinated, since its stretching vibration did not move significantly.

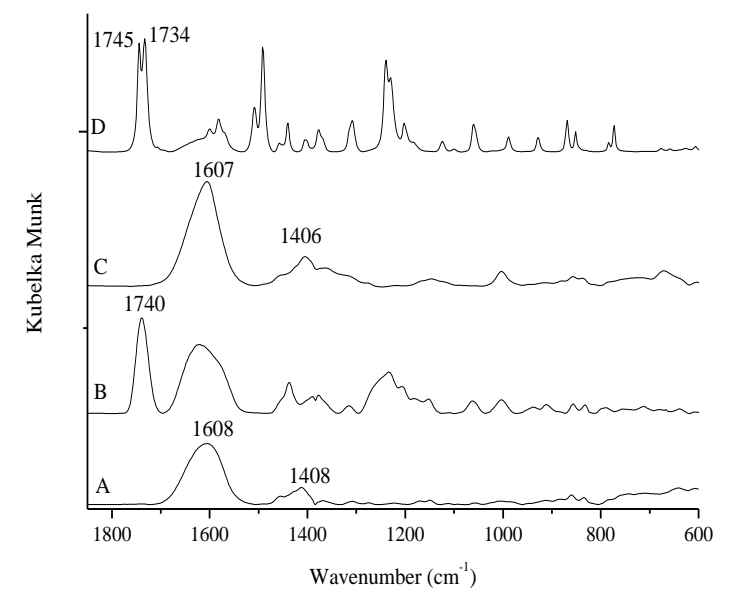

Figure 36 The IR spectra of A - SG-Cys-OMe-Co(II), B - SG-Cys-OMe-Co(II)-H-Cys-OMe, C - SG-(Cys-OMe $)_{2}-\mathrm{Co}(\mathrm{II})$, $\mathrm{D}-\mathrm{SG}-(\mathrm{Cys}-\mathrm{OMe})_{2}-\mathrm{Co}(\mathrm{II})-(\mathrm{H}-\mathrm{Cys}-\mathrm{OMe})_{2}$.

The increase in $\Delta$ for SG-(Cys-OMe) ${ }_{2}-\mathrm{Co}$ (II) (Figure 36, trace $\mathrm{C}$ ), confirms the coordination of the carboxylate oxygen. Adding C-protected cystine rearranged the ligand-poor complex (Figure 36, trace D), the carbonyl oxygens did not participate in the complexation, since the position of the bands $\left(1745,1734 \mathrm{~cm}^{-1}\right)$ did not move relative to the pristine amino acid. The only way for coordination to occur is via the amino nitrogens.

The proposed coordination environments are as follows:

SG-Cys-OMe-Co(II)

$\mathrm{S}_{\text {thiolateCyssurf }} \mathrm{O}_{\text {carboxylateCysssurf }} \mathrm{H}_{2} \mathrm{O}, \mathrm{H}_{2} \mathrm{O}, \mathrm{H}_{2} \mathrm{O}, \mathrm{H}_{2} \mathrm{O}$,

SG-Cys-OMe-Co(II)-H-Cys-OMe

$\mathrm{S}_{\text {thiolateCyssurf }} \mathrm{O}_{\text {carboxylateCysssurf }} \mathrm{S}_{\text {thiolateCys }} \mathrm{S}_{\text {thiolateCys }} \mathrm{H}_{2} \mathrm{O}, \mathrm{H}_{2} \mathrm{O}$,

$\mathrm{SG}-(\mathrm{Cys}-\mathrm{OMe})_{2}-\mathrm{Co}(\mathrm{II})$

$\mathrm{O}_{\text {carboxylate(Cys)2surf }} \mathrm{O}_{\text {carboxylate(Cys)2surf }} \mathrm{H}_{2} \mathrm{O}, \mathrm{H}_{2} \mathrm{O}, \mathrm{H}_{2} \mathrm{O}, \mathrm{H}_{2} \mathrm{O}$, 
SG-(Cys-OMe $)_{2}-\mathrm{Co}(\mathrm{II})-(\mathrm{H}-\mathrm{Cys}-\mathrm{OMe})_{2}$

$\mathrm{O}_{\text {carboxylate(Cys)2surf }} \mathrm{O}_{\text {carboxylate(Cys)2surf }} \mathrm{N}_{\text {amino(Cys) } 2} \mathrm{~N}_{\text {amino(Cys)2 }} \mathrm{H}_{2} \mathrm{O}, \mathrm{H}_{2} \mathrm{O}$.

Traces A (SG-His-OMe-Co(II)-H-Cys-OMe) and B (SG-Cys-OMe-Co(II)-HHis-OMe ) in Figure 37, predominantly show the features of the added amino acid esters. Their carbonyl frequencies in the anchored complexes practically remain at the position of the pristine esters. Trace C (SG-His-OMe;Cys-OMe-Co(II)) shows the mixture of the anchored amino acids, indicating the coordination of carboxylate oxygens in both amino acids of the 1:1 mixture. Under ligand-excess conditions (trace D), the surface complex rearranges but only the histidine methylester coordinates from the $1: 1$ mixture.

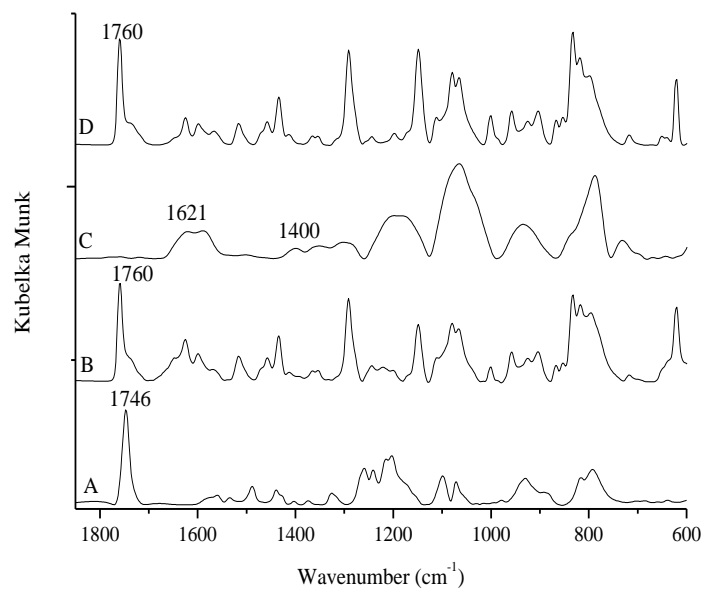

Figure 37 The IR spectra of A - SG-His-OMe-Co(II)-H-Cys-OMe, B - SG-Cys-OMe-Co(II)-H-His-OMe, C - SG-His-OMe;Cys-OMe-Co(II), D - SG-His-OMe;Cys-OMe-Co(II)-H-His-OMe; H-Cys-OMe.

The following structures for the covalently immobilised complexes can be proposed:

SG-His-OMe-Co(II)-H-Cys-OMe

$\mathrm{N}_{\text {imidazoleHissurf }} \mathrm{O}_{\text {carboxylateHissurf }} \mathrm{S}_{\text {thiolateCys }} \mathrm{S}_{\text {thiolateCys }} \mathrm{H}_{2} \mathrm{O}, \mathrm{H}_{2} \mathrm{O}$,

SG-Cys-OMe-Co(II)-H-His-OMe

$\mathrm{S}_{\text {thiolateCyssurf }} \mathrm{O}_{\text {carboxylateCysssurf }} \mathrm{N}_{\text {imidazoleHis }} \mathrm{N}_{\text {imidazoleHis }} \mathrm{H}_{2} \mathrm{O}, \mathrm{H}_{2} \mathrm{O}$,

SG-His-OMe;Cys-OMe-Co(II)

$\mathrm{N}_{\text {imidazoleHissurf }} \mathrm{O}_{\text {carboxylateHissurf }} \mathrm{S}_{\text {thiolateCyssurf }} \mathrm{O}_{\text {carboxylateCysssurf }} \mathrm{H}_{2} \mathrm{O}, \mathrm{H}_{2} \mathrm{O}$,

SG-His-OMe;Cys-OMe-Co(II)-H-His-OMe;H-Cys-OMe

$\mathrm{N}_{\text {imidazoleHissurf }} \mathrm{O}_{\text {carboxylateHissurf }} \mathrm{S}_{\text {thiolateCyssurf }} \mathrm{O}_{\text {carboxylateCysssurf }} \mathrm{N}_{\text {imidazoleHis }} \mathrm{H}_{2} \mathrm{O}$. 
In Figure 38, trace $\mathrm{A}$ shows the spectrum of SG-His-OMe-Co(II)-(H-Cys$\mathrm{OMe})_{2}$. C-protected cystine can only coordinate with its amino nitrogens, since the stretching vibration of the carbonyl bands $\left(1745,1734 \mathrm{~cm}^{-1}\right)$ did not shift. The carbonyl oxygen is not coordinated in SG-(Cys-OMe $)_{2}-\mathrm{Co}(\mathrm{II})-\mathrm{H}-\mathrm{His}-\mathrm{OMe}$ (Figure 38, trace $\mathrm{B}$ ): its vibration is not shifted.

When the amino acids are anchored in 1:1 mixture, forming SG-His-OMe;(Cys$\mathrm{OMe})_{2}-\mathrm{Co}$ (II) (Figure 38, trace C), the vibrations of the carboxylate groups cannot be deconvoluted, that is they are assumed to coordinate the same way as if they were used separately. The spectrum of the complex prepared under ligand-excess conditions (Figure 38, trace D), is very similar to that of the ligand-poor complex, a very tiny amount of C-protected cystine may coordinate, since its carbonyl vibrations appear at 1744 and $1735 \mathrm{~cm}^{-1}$ with low intensity.

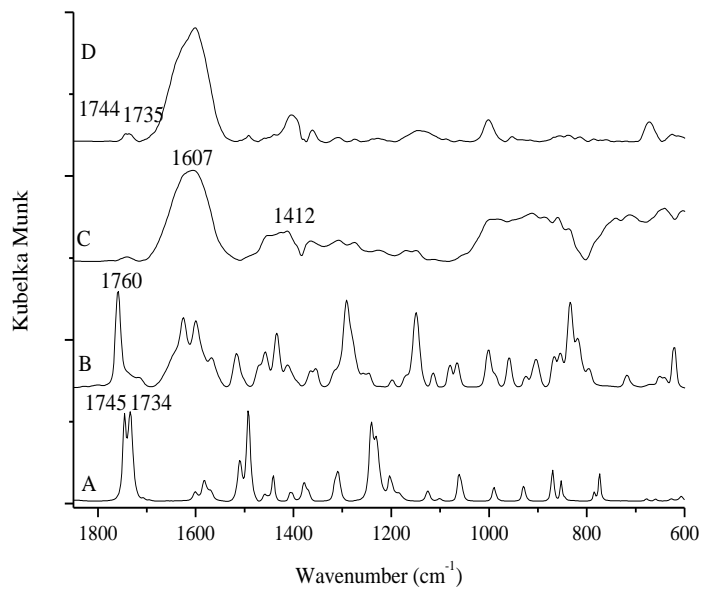

Figure 38 The IR spectra of A - SG-His-OMe-Co(II)-(H-Cys-OMe $)_{2}$, B - SG-(Cys-OMe) $)_{2}-\mathrm{Co}(\mathrm{II})-\mathrm{H}-\mathrm{His}-\mathrm{OMe}, \mathrm{C}-\mathrm{SG}-\mathrm{His}-\mathrm{OMe} ;(\mathrm{Cys}-\mathrm{OMe})_{2}-\mathrm{Co}(\mathrm{II})$, $\mathrm{D}$ - SG-His-OMe;(Cys-OMe $)_{2}-\mathrm{Co}(\mathrm{II})-\mathrm{H}-\mathrm{His}-\mathrm{OMe} ;(\mathrm{H}-\mathrm{Cys}-\mathrm{OMe})_{2}$.

These observations boil down to the following structural proposals:

SG-His-OMe-Co(II)-(H-Cys-OMe $)_{2}$

$\mathrm{N}_{\text {imidazoleHissurf }} \mathrm{O}_{\text {carboxylateHissurf }} \mathrm{N}_{\text {amino(Cys) } 2} \mathrm{~N}_{\text {amino(Cys) } 2} \mathrm{H}_{2} \mathrm{O}, \mathrm{H}_{2} \mathrm{O}$,

SG-(Cys-OMe $)_{2}-\mathrm{Co}(\mathrm{II})-\mathrm{H}-\mathrm{His}-\mathrm{OMe}$

$\mathrm{O}_{\text {carboxylate(Cys)2surf }} \mathrm{O}_{\text {carboxylate(Cys)2surf }} \mathrm{N}_{\text {imidazoleHis }} \mathrm{N}_{\text {imidazoleHis }} \mathrm{H}_{2} \mathrm{O}, \mathrm{H}_{2} \mathrm{O}$,

SG-His-OMe;(Cys-OMe) $)_{2}-\mathrm{Co}(\mathrm{II})$

$\mathrm{N}_{\text {imidazoleHissurf }} \mathrm{O}_{\text {carboxylateHissurf }} \mathrm{O}_{\text {carboxylate(Cys)2surf }} \mathrm{O}_{\text {carboxylate(Cys)2surf }} \mathrm{H}_{2} \mathrm{O}, \mathrm{H}_{2} \mathrm{O}$,

SG-His-OMe;(Cys-OMe) ${ }_{2}-\mathrm{Co}(\mathrm{II})-\mathrm{H}-\mathrm{His}-\mathrm{OMe} ;(\mathrm{H}-\mathrm{Cys}-\mathrm{OMe})_{2}$

$\mathrm{N}_{\text {imidazoleHissurf }} \mathrm{O}_{\text {carboxylateHissurf }} \mathrm{O}_{\text {carboxylate(Cys)2surf }} \mathrm{N}_{\text {amino(Cys)2 } 2} \mathrm{H}_{2} \mathrm{O}, \mathrm{H}_{2} \mathrm{O}$. 


\subsubsection{Testing the superoxide dismutase activity}

All materials could catalyse the dismutation the superoxide radical anion. Catalytic activities differed widely though (Table 10). In general, surface-anchored complexes prepared under ligand-excess conditions are more active than the others. It seems that the more coordinating group replace water molecules the more the catalytic activity is. There is an exception, since SG-His-OMe;Cys-OMe-Co(II) is the most active complex. Immobilised Co(II) complexes are less active than the Mn(II)- and $\mathrm{Fe}(\mathrm{III})$-containing complexes.

Table 10 The SOD activities of the surface grafted complexes. The best catalysts are highlighted in red.

\begin{tabular}{lc}
\hline Materials & $\mathrm{IC}_{50}(\mu \mathrm{M})$ \\
\hline Cu,ZnSOD enzyme & 0.4 \\
SG-His-OMe-Co(II) & 340 \\
SG-His-OMe-Co(II)-H-His-OMe & 50 \\
SG-Tyr-OMe-Co(II) & 151 \\
SG-Cys-OMe-Co(II) & 273 \\
SG-Cys-OMe-Co(II)-H-Cys-OMe & 84 \\
SG-(Cys-OMe) ${ }_{2}-\mathrm{Co}(\mathrm{II})$ & 149 \\
SG-(Cys-OMe) ${ }_{2}-\mathrm{Co}(\mathrm{II})-\mathrm{H}-(\mathrm{Cys}-\mathrm{OMe})_{2}$ & 99 \\
SG-His-OMe-Co(II)-H-Cys-OMe & 50 \\
SG-Cys-OMe-Co(II)-H-His-OMe & 80 \\
SG-His-OMe;Cys-OMe-Co(II) & 35 \\
SG-His-OMe;Cys-OMe-Co(II)-H-His-OMe;H-Cys-OMe & 47 \\
SG-His-OMe-Co(II)-(H-Cys-OMe) ${ }_{2}$ & 44 \\
SG-(Cys-OMe) ${ }_{2}-\mathrm{Co}(\mathrm{II})-H-H i s-O M e$ & 58 \\
SG-His-OMe;(Cys-OMe) ${ }_{2}-\mathrm{Co}(\mathrm{II})$ & 61 \\
SG-His-OMe;(Cys-OMe) ${ }_{2}-\mathrm{Co}(\mathrm{II})-\mathrm{H}-\mathrm{His}-\mathrm{OMe}(\mathrm{H}-\mathrm{Cys}-\mathrm{OMe})_{2}$ & 59 \\
\hline
\end{tabular}

\subsection{Silica-anchored $\mathrm{Ni}(\mathrm{II})$ complexes}

\subsubsection{Analytical measurements}

The results of the Kjeldahl method and the ICP-MS measurements are displayed in Table 11. 
Table 11 Amino acid and $\mathrm{Ni}^{2+}$ content of the samples obtained from Kjeldahl type Ndetermination and ICP-MS measurements.

\begin{tabular}{lcc}
\hline Sample & $\begin{array}{c}\text { Amino acid content } \\
(\mathrm{mmol} / \mathrm{g})\end{array}$ & $\begin{array}{c}\mathrm{Ni}^{2+} \text { content } \\
(\mathrm{mmol} / \mathrm{g})\end{array}$ \\
\hline SG-His-OMe-Ni(II) & 0.576 & 0.320 \\
SG-His-OMe-Ni(II)-H-His-OMe & 2.296 & 0.345 \\
SG-Cys-OMe-Ni(II) & 0.554 & \\
SG-Cys-OMe-Ni(II)-H-Cys-OMe & 1.091 & 0.384 \\
SG-(Cys-OMe $)_{2}-\mathrm{Ni}(\mathrm{II})$ & 0.505 & \\
SG-(Cys-OMe $)_{2}-\mathrm{Ni}(\mathrm{II})-\mathrm{H}-(\mathrm{Cys}-\mathrm{OMe})_{2}$ & 0.664 & \\
\hline
\end{tabular}

Covalent anchoring of the amino acids was successful in all cases. The conversion of the immobilisation is ranged from $72-82 \%$. Under ligand-poor conditions the metal ion to amino acid ratio is $1: 1.8$ for $\mathrm{SG}-\mathrm{His}-\mathrm{OMe}-\mathrm{Ni}(\mathrm{II}), 1: 1.6$ for $\mathrm{SG}-\mathrm{Cys}-\mathrm{OMe}-\mathrm{Ni}$ (II) and $1: 1.3$ for $\mathrm{SG}-(\mathrm{Cys}-\mathrm{OMe})_{2}-\mathrm{Ni}(\mathrm{II})$. It means that the complexes formed on the surface are not uniform, there are complexes having 1:1 as well as 1:2 metal to ligand ratios. Under ligand-excess conditions, for SG-His-OMe-Ni(II)-H-His-OMe, this ratio is 1:7.2, suggesting that there are non-coordinating histidine molecules on the surface of the silica gel. For SG-Cys-OMe-Ni(II)-H-Cys-OMe the ratio is 1:3.2, while it is only 1:1.7 for SG-(Cys-OMe $)_{2}-\mathrm{Ni}(\mathrm{II})-\mathrm{H}-(\mathrm{Cys}-\mathrm{OMe})_{2}$, indicating that cystine molecules can saturate the coordination sphere of nickel ions more effectively, since they have more coordinating groups.

\subsubsection{UV-Vis diffuse reflectance spectroscopy}

The solid-state electronic spectra of all the immobilised $\mathrm{Ni}$ (II) complexes exhibit two broad bands at around 700 and $400 \mathrm{~nm}$ assigned to the ${ }^{3} \mathrm{~A}_{2 \mathrm{~g}}(\mathrm{~F}) \rightarrow{ }^{3} \mathrm{~T}_{1 \mathrm{~g}}(\mathrm{~F})(\mathrm{v} 2)$ and ${ }^{3} \mathrm{~A}_{2 \mathrm{~g}}(\mathrm{~F}) \rightarrow{ }^{3} \mathrm{~T}_{1 \mathrm{~g}}(\mathrm{P})$ (v3) transitions, respectively, which are typical for the hexacoordinated (octahedral) geometry. Exemplary spectra of the ligand-poor complexes formed with uniform amino acid are depicted in Figure 39. 


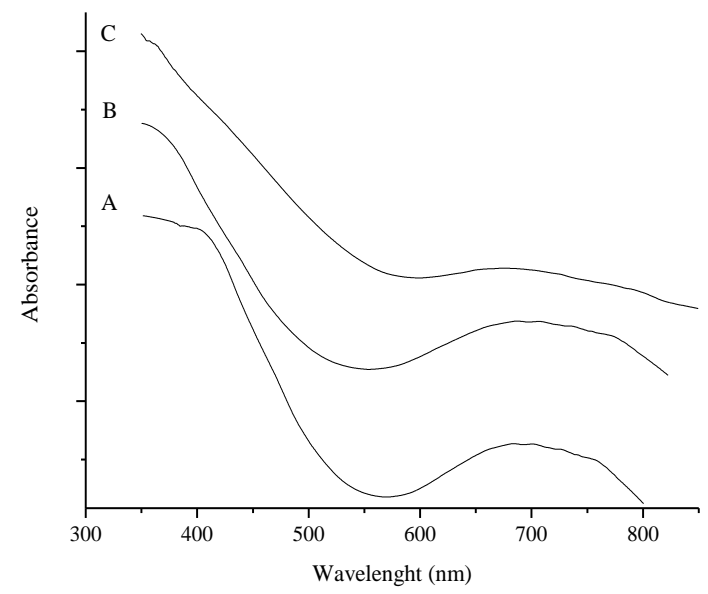

Figure 39 The UV-Vis diffuse reflectance spectra of A - SG-His-OMe-Ni(II), B - SG-Cys-OMe-Ni(II), C - SG-(Cys-OMe $)_{2}-\mathrm{Ni}(\mathrm{II})$.

\subsubsection{X-ray absorption measurements}

Ni K-edge XAS spectra were recorded for four complexes. The XANES spectra of the materials are displayed in Figure 40. The spectra are roughly superimposable, indicating local structure of $\mathrm{Ni}$ (II) being more or less independent of the type of coordinating ligand. A very small pre-edge peak around $8332 \mathrm{eV}$ corresponding to $1 \mathrm{~s} \rightarrow 3 \mathrm{~d}$ transition, the main absorption edge around $8350 \mathrm{eV}$, assigned to the $1 \mathrm{~s} \rightarrow 4 \mathrm{p}$ transition, and significant oscillation in the $8360-8430 \mathrm{eV}$ range can be observed. In square pyramidal and tetrahedral complexes, the pre-edge is more intense, while for square planar geometry, the splitting of the main edge peak can be observed due to the $1 \mathrm{~s} \rightarrow 4 \mathrm{p}_{\mathrm{z}}$ and the $1 \mathrm{~s} \rightarrow 4 \mathrm{p}_{\mathrm{x}, \mathrm{y}}$ transitions [142]. Accordingly, these results suggest, that the $\mathrm{Ni}(\mathrm{II})$ ion in the immobilised complexes is in an octahedral coordination environment. This result is in accordance with the diffuse reflectance observations. The Ni K-edge position is shifted towards lower energies for SG-Cys-OMe-Ni(II) and SG-His-OMe$\mathrm{Ni}(\mathrm{II})-\mathrm{H}-\mathrm{Cys}-\mathrm{OMe}$ relative to the other two grafted complexes; it may indicate the coordination of the thiolate group. 


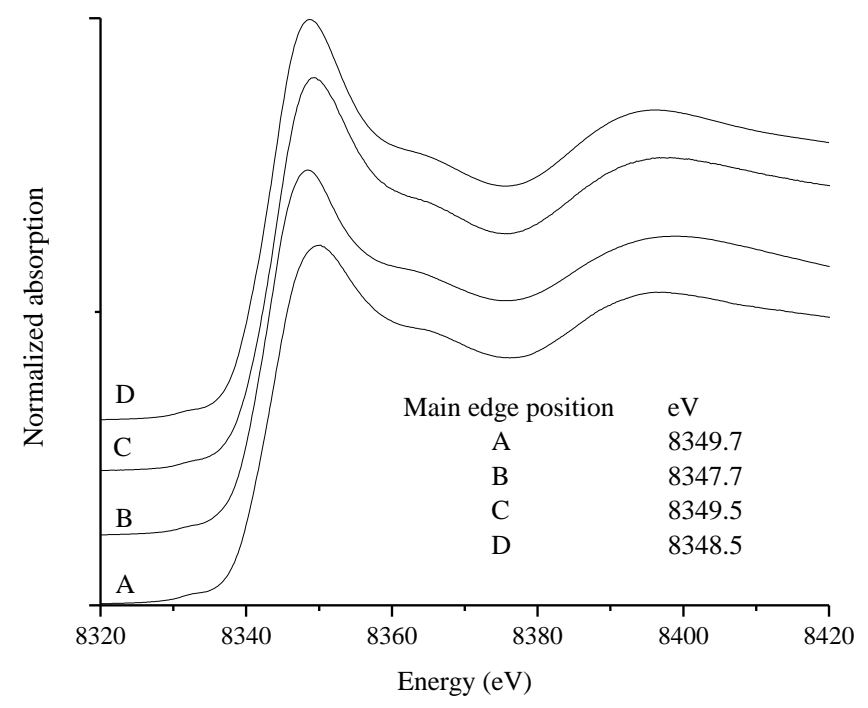

Figure 40 The Ni K-edge XANES spectra of A - SG-His-OMe-Ni(II),

$\mathrm{B}$ - SG-Cys-OMe-Ni(II), C - SG-(Cys-OMe) $)_{2}-\mathrm{Ni}(\mathrm{II})$,

$\mathrm{D}$ - SG-His-OMe-Ni(II)-H-Cys-OMe.

The Fourier-transformed EXAFS data (without phase correction) are displayed in Figure 41, and the results of the fitting are shown in Table 12. For SG-His-OMe-Ni(II), the EXAFS analysis showed that the first coordination shell contained six oxygen/nitrogen atoms, where the $\mathrm{Ni}(\mathrm{II})-\mathrm{O} / \mathrm{N}$ bond distance was found to be $2.07 \AA$. This value is close to that obtained from XAFS measurements for the octahedral $\left[\mathrm{Ni}\left(\mathrm{H}_{2} \mathrm{O}\right)_{6}\right]^{2+}$ complex (it was $2.05 \AA$ ), where $\mathrm{Ni}(\mathrm{II})$ was coordinated by six $\mathrm{O}$ atoms [131]. The EXAFS measurement indicated that six oxygen/nitrogen atoms formed the first coordination sphere of $\mathrm{SG}-(\mathrm{Cys}-\mathrm{OMe})_{2}-\mathrm{Ni}(\mathrm{II})$ as well with a $\mathrm{Ni}(\mathrm{II})-\mathrm{O} / \mathrm{N}$ bond length of $2.07 \AA$. For SG-Cys-OMe-Ni(II), two different interatomic distances can be separated in the first shell. The first one is related to the $\mathrm{Ni}(\mathrm{II})-\mathrm{O} / \mathrm{N}$ distance $(\mathrm{R}=2.12$ $\AA$ ) with a coordination number of 4.5 , while the second peak corresponds to a $\mathrm{Ni}(\mathrm{II})-\mathrm{S}$ distance of $2.43 \AA$, and a coordination number of 1.5 . 


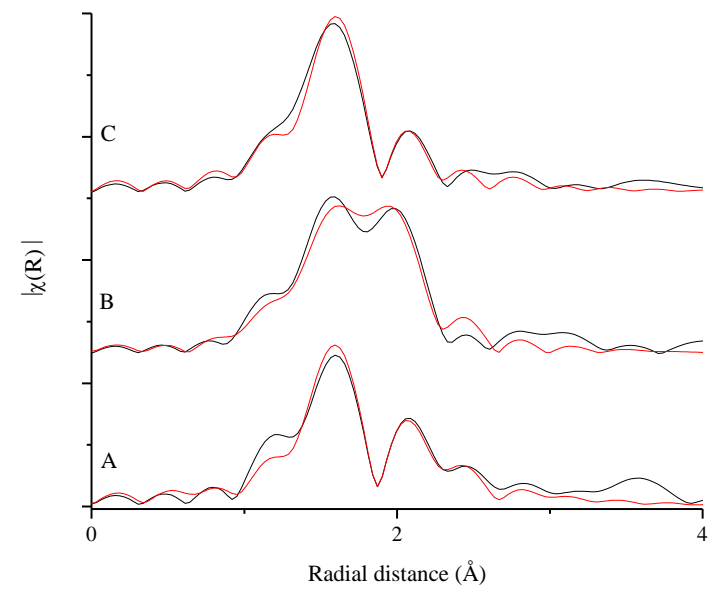

Figure 41 The Fourier-transformed EXAFS data (without phase correction) of A - SG-His-OMe-Ni(II), B - SG-(Cys-OMe) $)_{2}-\mathrm{Ni}(\mathrm{II}), \mathrm{C}-\mathrm{SG}-\mathrm{Cys}-\mathrm{OMe}-\mathrm{Ni}(\mathrm{II})$, red line - fitted, black line - experimental.

Table 12 Parameters deduced from the fitted EXAFS spectra ( $\mathrm{N}$ - coordination number, $\mathrm{R}$ - bond length, $\sigma^{2}$ - Debye-Waller factor, $\Delta \mathrm{E}_{0}$ - energy shift, $\mathrm{R}$ factor - goodness of fit).

\begin{tabular}{lllllll}
\hline Sample & $\left(\mathrm{Ni}^{2+}-\right) \mathrm{X}$ & $\mathrm{N}$ & $\mathrm{R}(\AA)$ & $\sigma^{2}\left(\AA^{2}\right)$ & $\Delta \mathrm{E}_{0}(\mathrm{eV})$ & $\mathrm{R}$ factor \\
\hline SG-His-OMe-Ni(II) & $\mathrm{O} / \mathrm{N}$ & 6 & 2.07 & 0.0048 & 0.61 & 0.0312 \\
SG-Cys-OMe-Ni(II) & $\mathrm{O} / \mathrm{N}$ & 4.5 & 2.12 & 0.0106 & 0.85 & 0.0157 \\
& $\mathrm{~S}$ & 1.5 & 2.43 & 0.0035 & & \\
& & & & & & \\
SG-(Cys-OMe) $)_{2}-\mathrm{Ni}(\mathrm{II})$ & $\mathrm{O} / \mathrm{N}$ & 6 & 2.07 & 0.0045 & 0.37 & 0.0182 \\
\hline
\end{tabular}

\subsubsection{FT-IR spectroscopy}

$\Delta$ is found to be $207 \mathrm{~cm}^{-1}\left[\Delta=1610 \mathrm{~cm}^{-1}-1403 \mathrm{~cm}^{-1}\right.$ ] for the SG-His-OMe$\mathrm{Ni}(\mathrm{II})$, (Figure 42, trace A). This difference indicates that the carboxylate group is involved in the coordination as monodentate ligand. In the far IR spectrum of the complex (Figure 43, trace A), the vibration at $259 \mathrm{~cm}^{-1}$ confirms the coordination of the imidazole nitrogen, the band at $353 \mathrm{~cm}^{-1}$ belongs to the $\mathrm{Ni}-\mathrm{O}_{\text {carboxylate }}$ vibration, while the bands above $400 \mathrm{~cm}^{-1}$ can be assigned as ligand and $\mathrm{Ni}-$ coordinated water vibrations. 


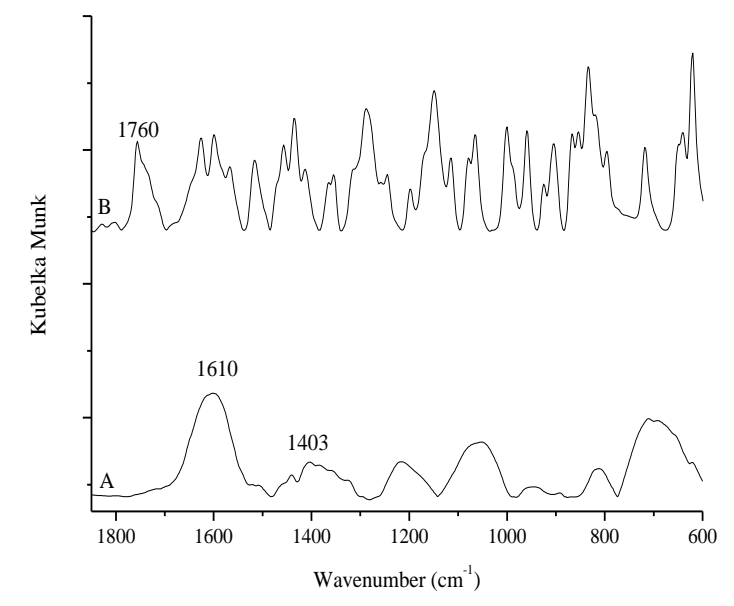

Figure 42 The IR spectra of A - SG-His-OMe-Ni(II), B - SG-His-OMe-Ni(II)-H-His-OMe.

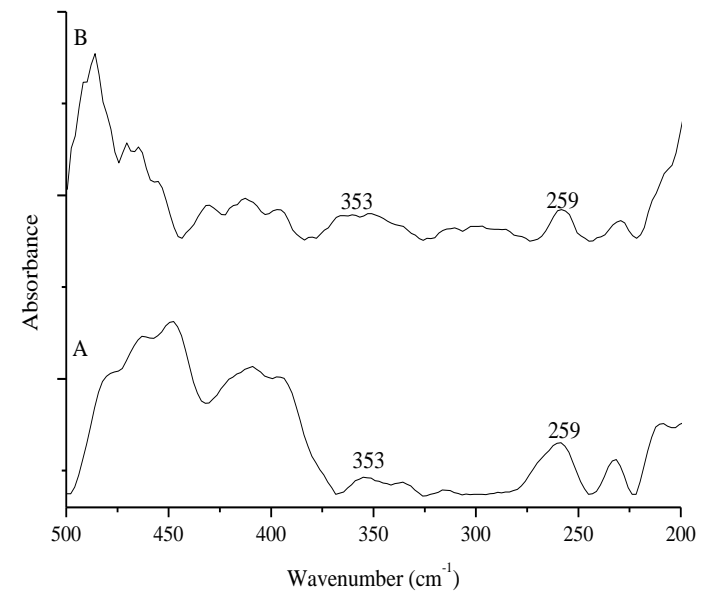

Figure 43 The far IR spectra of A - SG-His-OMe-Ni(II), B - SG-His-OMe-Ni(II)-H-His-OMe.

The difference spectrum of SG-His-OMe-Ni(II)-H-His-OMe (Figure 42, trace B) is very similar to the spectrum of C-protected histidine; the carbonyl band is split, indicating that the carbonyl oxygen appears in the coordination sphere of the metal ion, but there are non-coordinating amino acids as well. This observation is supported by the analytical measurements (see the $\mathrm{N}$ and $\mathrm{Ni}(\mathrm{II})$ contents in Table 11). The vibration for the $\mathrm{Ni}(\mathrm{II})-\mathrm{N}_{\text {imidazole }}$ bond is observed at $259 \mathrm{~cm}^{-1}$, the bands above $400 \mathrm{~cm}^{-1}$ can be assigned as ligand and coordinated water vibrations (Figure 43, trace B).

Putting together all the information, structural proposals for the surface-bound complexes are offered as follows: 
SG-His-OMe-Ni(II)

$\mathrm{N}_{\text {imidazoleHissurf }} \mathrm{O}_{\text {carboxylateHissurf }} \mathrm{H}_{2} \mathrm{O}, \mathrm{H}_{2} \mathrm{O}, \mathrm{H}_{2} \mathrm{O}, \mathrm{H}_{2} \mathrm{O}$,

SG-His-OMe-Ni(II)-H-His-OMe

$\mathrm{N}_{\text {imidazoleHissurf }} \mathrm{O}_{\text {carboxylateHissurf }} \mathrm{O}_{\text {carbonylHis }} \mathrm{N}_{\text {imidazoleHis }} \mathrm{H}_{2} \mathrm{O}, \mathrm{H}_{2} \mathrm{O}$.

As far as SG-Cys-OMe-Ni(II) is concerned (Figure 44, trace A), $\Delta=1606 \mathrm{~cm}^{-1}-$ $1409 \mathrm{~cm}^{-1}=197 \mathrm{~cm}^{-1}$ indicating monodentate ligation of the carboxylate group. In the far IR range, the band at $355 \mathrm{~cm}^{-1}$ confirms the complexation of the carboxylate oxygen. Under ligand-excess conditions (trace B), the carbonyl band is not coordinated to the nickel ion, since the position of the band does not shift relative to the pristine amino acid. The lack of the $\mathrm{S}-\mathrm{H}$ vibration proves that the thiolate group takes part in the complexation, as it was also learnt from the XAS measurement.

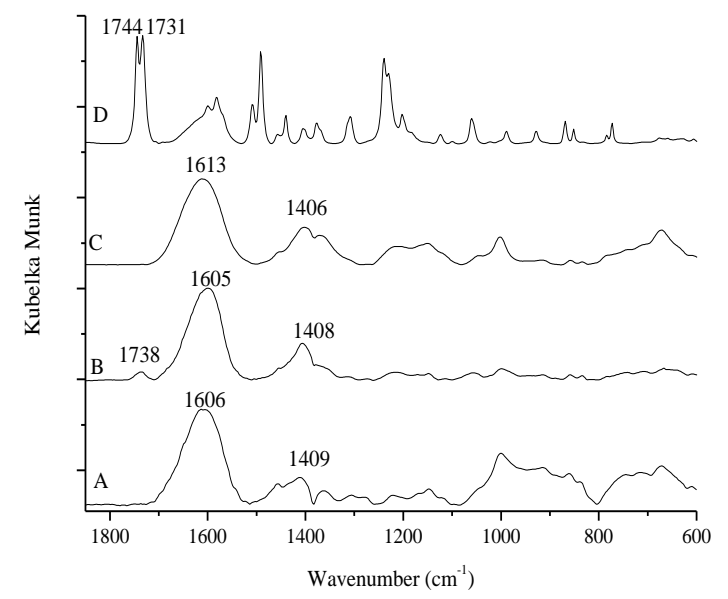

Figure 44 The IR spectra of A - SG-Cys-OMe-Ni(II), B - SG-Cys-OMe-Ni(II)-H-Cys-OMe, C - SG-(Cys-OMe $)_{2}-\mathrm{Ni}(\mathrm{II})$, $\mathrm{D}-\mathrm{SG}-(\mathrm{Cys}-\mathrm{OMe})_{2}-\mathrm{Ni}(\mathrm{II})-(\mathrm{H}-\mathrm{Cys}-\mathrm{OMe})_{2}$.

For SG-(Cys-OMe) $)_{2}-\mathrm{Ni}(\mathrm{II})$ (Figure 44, trace C), the carboxylate group was involved in the coordination as monodentate ligand, since $\Delta$ increased from $185 \mathrm{~cm}^{-1}$ to $207 \mathrm{~cm}^{-1}$. In the far IR range the peak at $354 \mathrm{~cm}^{-1}$ corresponds to the $\mathrm{Ni}-\mathrm{O}_{\text {carboxylate }}$ vibration and a new band appeared at $373 \mathrm{~cm}^{-1}$ due to the coordination of amino nitrogen. Adding C-protected cystine in excess (trace D) resulted in the rearrangement of the surface-grafted ligand-poor complex. The carbonyl oxygens are not coordinated, since the stretching vibrations of the carbonyl bands $\left(1746\right.$ and $\left.1734 \mathrm{~cm}^{-1}\right)$ did not shift 
to lower wavenumbers. This is the reason why the added C-protected cystine molecules are coordinated with their amino nitrogens.

Structural proposals for the surface-bound complexes are offered as follows:

SG-Cys-OMe-Ni(II)

$\mathrm{S}_{\text {thiolateCyssurf }} \mathrm{O}_{\text {carboxylateCysssurf }} \mathrm{S}_{\text {thiolateCyssurf }} \mathrm{O}_{\text {carboxylateCysssurf }}, \mathrm{H}_{2} \mathrm{O}, \mathrm{H}_{2} \mathrm{O}$,

SG-Cys-OMe-Ni(II)-H-Cys-OMe

$\mathrm{S}_{\text {thiolateCyssurf }} \mathrm{O}_{\text {carboxylateCysssurf }} \mathrm{S}_{\text {thiolateCys }} \mathrm{S}_{\text {thiolateCys }} \mathrm{H}_{2} \mathrm{O}, \mathrm{H}_{2} \mathrm{O}$,

$\mathrm{SG}-(\mathrm{Cys}-\mathrm{OMe})_{2}-\mathrm{Ni}(\mathrm{II})$

$\mathrm{O}_{\text {carboxylate(Cys)2surf }} \mathrm{O}_{\text {carboxylate(Cys)2surf }} \mathrm{N}_{\text {amino(Cys)2surf }}, \mathrm{H}_{2} \mathrm{O}, \mathrm{H}_{2} \mathrm{O}, \mathrm{H}_{2} \mathrm{O}$,

SG-(Cys-OMe $)_{2}-\mathrm{Ni}(\mathrm{II})-(\mathrm{H}-\mathrm{Cys}-\mathrm{OMe})_{2}$

$\mathrm{O}_{\text {carboxylate(Cys)2surf }} \mathrm{O}_{\text {carboxylate(Cys)2surf }} \mathrm{N}_{\text {amino(Cys)2surf }} \mathrm{N}_{\text {amino(Cys)2 }} \mathrm{N}_{\text {amino(Cys) }} \mathrm{H}_{2} \mathrm{O}$.

The spectrum of SG-His-OMe-Ni(II)-H-Cys-OMe (Figure 46, trace A) is very similar to that of the pristine cysteine methylester, while spectrum B (SG-Cys-OMe$\mathrm{Ni}(\mathrm{II})-\mathrm{H}-\mathrm{His}-\mathrm{OMe}$ ) resembles that of the unanchored histidine methylester. This means that the added amino acid ester rearranged the complex prepared under ligand-poor conditions. Analysis of the spectra reveals that the carbonyl oxygen of the added Cprotected amino is not coordinated, since the position of the carbonyl band hardly changed relative to the free amino acid methylester. The absence of the $\mathrm{S}-\mathrm{H}$ vibration confirms that the thiolate sulphur participates in the complexation.

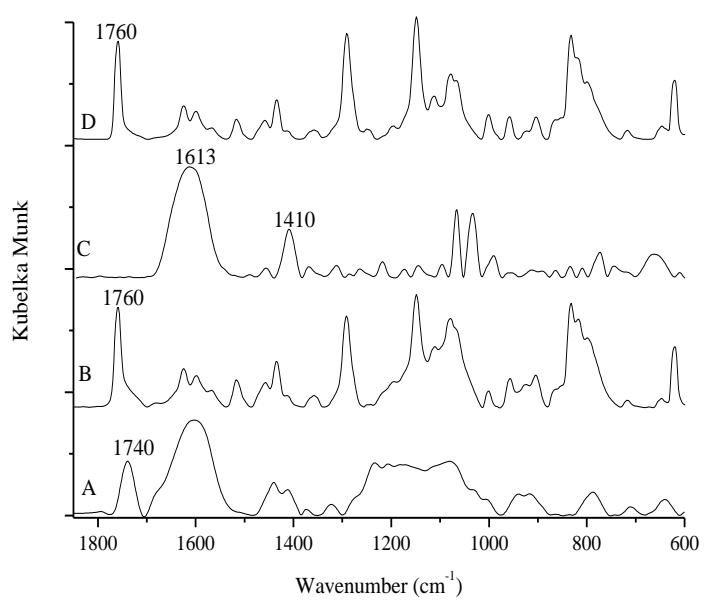

Figure 45 The IR spectra of A - SG-His-OMe-Ni(II)-H-Cys-OMe, B - SG-Cys-OMe-Ni(II)-H-His-OMe, C - SG-His-OMe;Cys-OMe-Ni(II), D - SG-His-OMe;Cys-OMe-Ni(II)-H-His-OMe;H-Cys-OMe. 
As far as SG-His-OMe;Cys-OMe-Ni(II) is concerned (Figure 45, trace C), the amino acids are proposed to coordinate the same way as if they were used separately. Spectrum D indicates that histidine methylester coordinates only from the 1:1 H-HisOMe, H-Cys-OMe mixture. It can also be learnt that its carbonyl oxygen is not a coordinating site, since its position did not shift on adding the mixture to the material prepared under ligand-poor conditions.

SG-His-OMe-Ni(II)-H-Cys-OMe

$\mathrm{N}_{\text {imidazoleHissurf }} \mathrm{O}_{\text {carboxylateHissurf }} \mathrm{S}_{\text {thiolateCys }} \mathrm{S}_{\text {thiolateCys }} \mathrm{H}_{2} \mathrm{O}, \mathrm{H}_{2} \mathrm{O}$,

SG-Cys-OMe-Ni(II)-H-His-OMe

$\mathrm{S}_{\text {thiolateCyssurf }} \mathrm{O}_{\text {carboxylateCysssurf }} \mathrm{N}_{\text {imidazoleHis }} \mathrm{N}_{\text {imidazoleHis }} \mathrm{H}_{2} \mathrm{O}, \mathrm{H}_{2} \mathrm{O}$,

SG-His-OMe;Cys-OMe-Ni(II)

$\mathrm{N}_{\text {imidazoleHissurf }} \mathrm{O}_{\text {carboxylateHissurf }} \mathrm{S}_{\text {thiolateCyssurf }} \mathrm{O}_{\text {carboxylateCysssurf }} \mathrm{H}_{2} \mathrm{O}, \mathrm{H}_{2} \mathrm{O}$,

SG-His-OMe;Cys-OMe-Ni(II)-H-His-OMe;H-Cys-OMe

$\mathrm{N}_{\text {imidazoleHissurf }} \mathrm{O}_{\text {carboxylateHissurf }} \mathrm{S}_{\text {thiolateCyssurf }} \mathrm{O}_{\text {carboxylateCysssurf }} \mathrm{N}_{\text {imidazoleHis }} \mathrm{H}_{2} \mathrm{O}$.

The addition of C-protected cystine in excess to $\mathrm{SG}-\mathrm{His}-\mathrm{OMe}-\mathrm{Ni}$ (II) rearranged the complex (Figure 46, trace A). The stretching vibration of the carbonyl bands did not move relative to the free $\mathrm{C}$-protected cysteine; therefore, it can only coordinate with the amino nitrogens.

In Figure 46, trace B shows the spectrum of SG-(Cys-OMe $)_{2}-\mathrm{Ni}(\mathrm{II})-\mathrm{H}-\mathrm{His}-\mathrm{OMe}$. The spectrum is very similar to that of the C-protected histidine; the carbonyl oxygen does not participate in the complexation.

In SG-His-OMe;(Cys-OMe $)_{2}-\mathrm{Ni}(\mathrm{II})$, the anchored amino acids coordinate as they did separately (Figure 46, trace C). Under ligand-excess conditions (Figure 46, trace D) only the unshifted vibrations of C-protected cystine can be seen, indicating that from the $1: 1$ mixture, it is only coordinated with the amino nitrogens. 


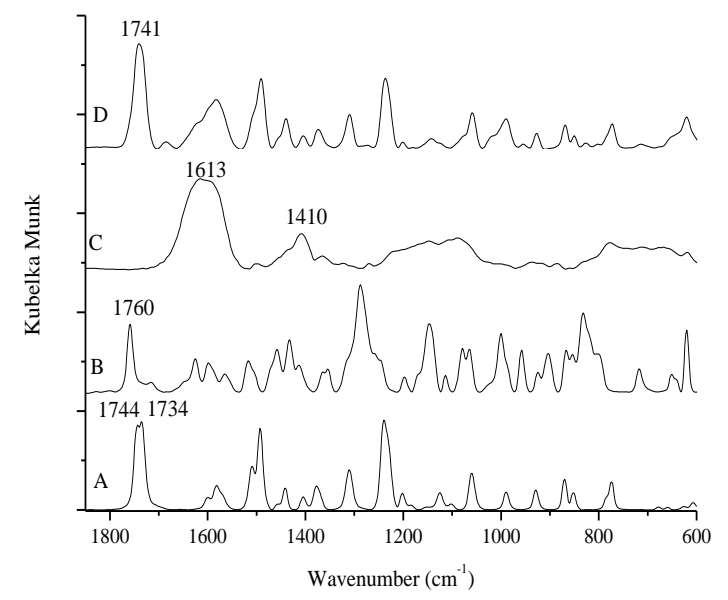

Figure 46 The IR spectra of A - SG-His-OMe-Ni(II)-(H-Cys-OMe $)_{2}$, $\mathrm{B}$ - SG-(Cys-OMe $)_{2}-\mathrm{Ni}(\mathrm{II})-\mathrm{H}-\mathrm{His}-\mathrm{OMe}, \mathrm{C}-\mathrm{SG}-\mathrm{His}-\mathrm{OMe}$;(Cys-OMe $)_{2}-\mathrm{Ni}(\mathrm{II})$, $\mathrm{D}$ - SG-His-OMe;(Cys-OMe $)_{2}-\mathrm{Ni}(\mathrm{II})-\mathrm{H}-\mathrm{His}-\mathrm{OMe} ;(\mathrm{H}-\mathrm{Cys}-\mathrm{OMe})_{2}$.

The following structures can be proposed for the anchored complexes:

SG-His-OMe-Ni(II)-(H-Cys-OMe $)_{2}$

$\mathrm{N}_{\text {imidazoleHissurf }} \mathrm{O}_{\text {carboxylateHissurf }} \mathrm{N}_{\text {amino(Cys) } 2} \mathrm{~N}_{\text {amino(Cys) } 2} \mathrm{H}_{2} \mathrm{O}, \mathrm{H}_{2} \mathrm{O}$,

$\mathrm{SG}-(\mathrm{Cys}-\mathrm{OMe})_{2}-\mathrm{Ni}(\mathrm{II})-\mathrm{H}-\mathrm{His}-\mathrm{OMe}$

$\mathrm{O}_{\text {carboxylate(Cys)2surf }} \mathrm{O}_{\text {carboxylate(Cys)2surf }} \mathrm{N}_{\text {amino(Cys)2surf }} \mathrm{N}_{\text {imidazoleHis }} \mathrm{N}_{\text {imidazoleHis }} \mathrm{H}_{2} \mathrm{O}$,

SG-His-OMe;(Cys-OMe $)_{2}-\mathrm{Ni}(\mathrm{II})$

$\mathrm{N}_{\text {imidazoleHissurf }} \mathrm{O}_{\text {carboxylateHissurf }} \mathrm{O}_{\text {carboxylate(Cys)2surf }} \mathrm{O}_{\text {carboxylate(Cys)2surf }} \mathrm{N}_{\text {amino(Cys)2surf }} \mathrm{H}_{2} \mathrm{O}$,

SG-His-OMe;(Cys-OMe) $)_{2}-\mathrm{Ni}(\mathrm{II})-\mathrm{H}-\mathrm{His}-\mathrm{OMe} ;(\mathrm{H}-\mathrm{Cys}-\mathrm{OMe})_{2}$

$\mathrm{N}_{\text {imidazoleHissurf }} \mathrm{O}_{\text {carboxylateHissurf }} \mathrm{O}_{\text {carboxylate(Cys)2surf }} \mathrm{N}_{\text {amino(Cys)2surf }} \mathrm{N}_{\text {amino(Cys)2 }} \mathrm{H}_{2} \mathrm{O}$.

\subsubsection{Testing the superoxide dismutase activity}

All materials were active in catalysing the dismutation reaction of the superoxide radical anion. Catalytic activities differed widely here, too (Table 13).

The most active material was SG-His-OMe-Ni(II) complex. Generally, the anchored $\mathrm{Ni}$ (II) complexes were more active than the $\mathrm{Cu}$ (II) and $\mathrm{Co}(\mathrm{II})$ complexes, but less active than the $\mathrm{Fe}(\mathrm{III})$ and $\mathrm{Mn}(\mathrm{II})$ complexes. 
Table 13 The SOD activities of the surface grafted complexes. The best catalyst is highlighted in red.

\begin{tabular}{lc}
\hline Materials & $\mathrm{IC}_{50}(\mu \mathrm{M})$ \\
\hline Cu,ZnSOD enzyme & 0.4 \\
SG-His-OMe-Ni(II) & 10 \\
SG-His-OMe-Ni(II)-H-His-OMe & 59 \\
SG-Cys-OMe-Ni(II) & 61 \\
SG-Cys-OMe-Ni(II)-H-Cys-OMe & 170 \\
SG-(Cys-OMe) ${ }_{2}-\mathrm{Ni}(\mathrm{II})$ & 79 \\
SG-(Cys-OMe) ${ }_{2}-\mathrm{Ni}(\mathrm{II})-\mathrm{H}-(\mathrm{Cys}-\mathrm{OMe})_{2}$ & 91 \\
SG-His-OMe-Ni(II)-H-Cys-OMe & 53 \\
SG-Cys-OMe-Ni(II)-H-His-OMe & 58 \\
SG-His-OMe;Cys-OMe-Ni(II) & 52 \\
SG-His-OMe;Cys-OMe-Ni(II)-H-His-OMe;H-Cys-OMe & 51 \\
SG-His-OMe-Ni(II)-(H-Cys-OMe) ${ }_{2}$ & 56 \\
SG-(Cys-OMe) ${ }_{2}-\mathrm{Ni}(\mathrm{II})-\mathrm{H}-\mathrm{His}-\mathrm{OMe}$ & 54 \\
SG-His-OMe;(Cys-OMe) ${ }_{2}-\mathrm{Ni}(\mathrm{II})$ & 51 \\
SG-His-OMe;(Cys-OMe) ${ }_{2}-\mathrm{Ni}(\mathrm{II})-\mathrm{H}-\mathrm{His}-\mathrm{OMe}$;(H-Cys-OMe) ${ }_{2}$ & 58 \\
\hline
\end{tabular}

\subsubsection{Catalytic oxidation of cyclohexene}

The conversion and selectivity results of the immobilised catalysts on the oxidation of cyclohexene with peracetic acid in acetone are reported in Table 14. 
Table 14 The conversion and selectivity results of the oxidation of cyclohexene after $3 \mathrm{~h}$.

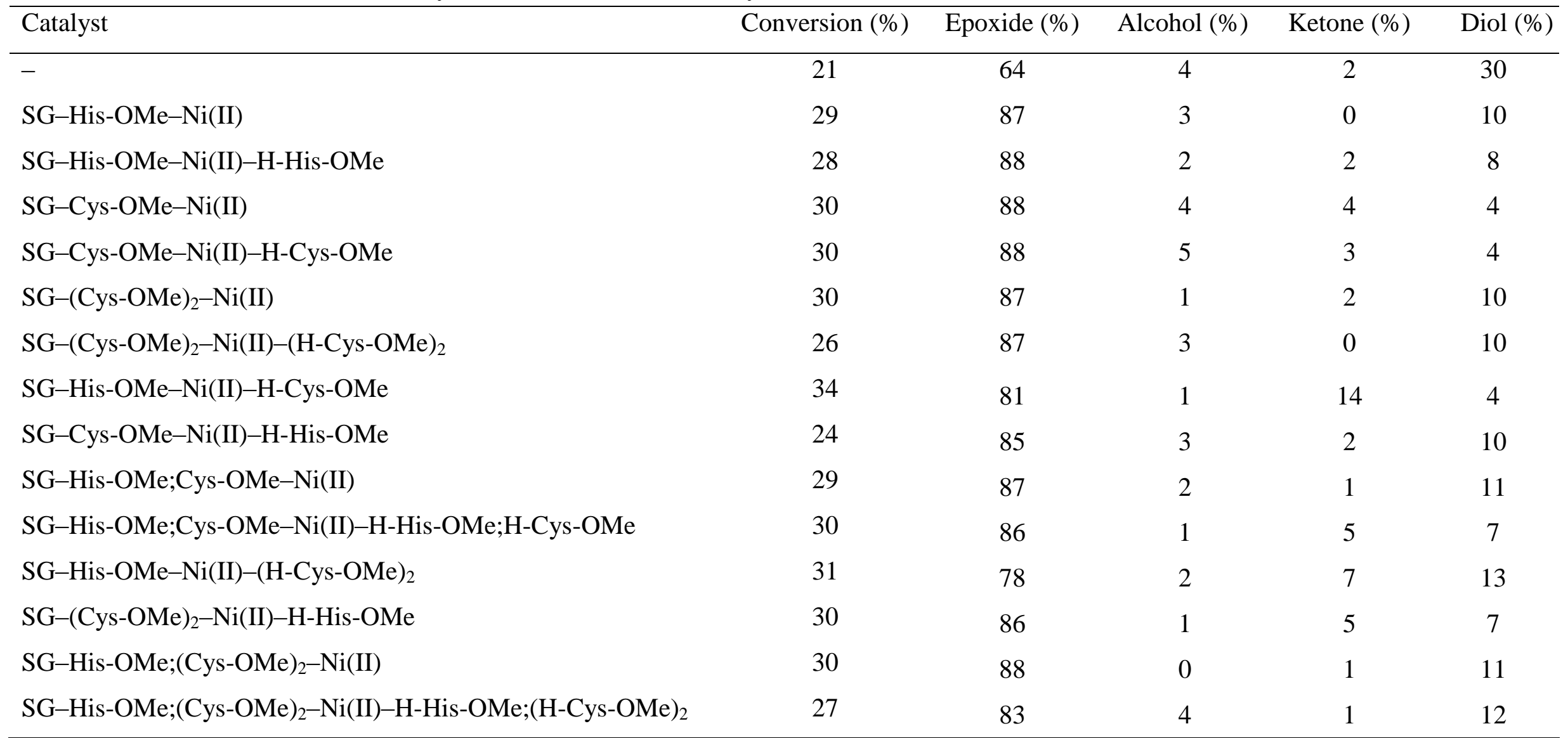


All the chosen immobilised complexes were catalytically active; however, the conversion levels reached were higher than that of the uncatalysed reaction only to a small extent. Nevertheless, selectivities shifted significantly towards epoxide formation due to the presence of the anchored complex. The conversions and the selectivities of the catalysed oxidation reactions are very similar to each other, indicating that they are independent of the type of the coordinating atoms.

\subsection{Silica-anchored $\mathrm{Cu}(\mathrm{II})$ complexes}

\subsubsection{Analytical measurements}

The results of the Kjeldahl method and the ICP-MS measurements for the immobilised $\mathrm{Cu}(\mathrm{II})$-complexes containing uniform amino acids as ligands are shown in Table 15 .

Table 15 Amino acid and $\mathrm{Cu}^{2+}$ content of the samples obtained from Kjeldahl type Ndetermination and ICP-MS measurements.

\begin{tabular}{lcc}
\hline Sample & $\begin{array}{c}\text { Amino acid content } \\
(\mathrm{mmol} / \mathrm{g})\end{array}$ & $\begin{array}{c}\mathrm{Cu}^{2+} \text { content } \\
(\mathrm{mmol} / \mathrm{g})\end{array}$ \\
\hline SG-His-OMe-Cu(II) & 0.438 & 0.378 \\
SG-His-OMe-Cu(II)-H-His-OMe & 2.130 & \\
SG-(Cys-OMe $)_{2}-\mathrm{Cu}(\mathrm{II})$ & 0.431 & 0.386 \\
SG-(Cys-OMe $)_{2}-\mathrm{Cu}(\mathrm{II})-\mathrm{H}-(\mathrm{Cys}-\mathrm{OMe})_{2}$ & 0.926 & \\
\hline
\end{tabular}

The conversion of the grafting is ranged from 61 to $69 \%$. As it was expected, mixture of various complexes was formed. Under ligand-poor conditions mostly 1:1 and 1:2 metal ion to amino acid ratios, while under ligand-excess conditions mainly 1:2 and 1:3 complexes can be envisaged.

\subsubsection{X-ray absorption measurements}

$\mathrm{Cu}$ K-edge XAS spectra were recorded for three complexes, one of them did not contain sulphur atom, while the other two did. Comparing their spectra helps to 
determine whether the sulphur atom is coordinated to the central ion. The XANES spectra of the materials are displayed in Figure 47.

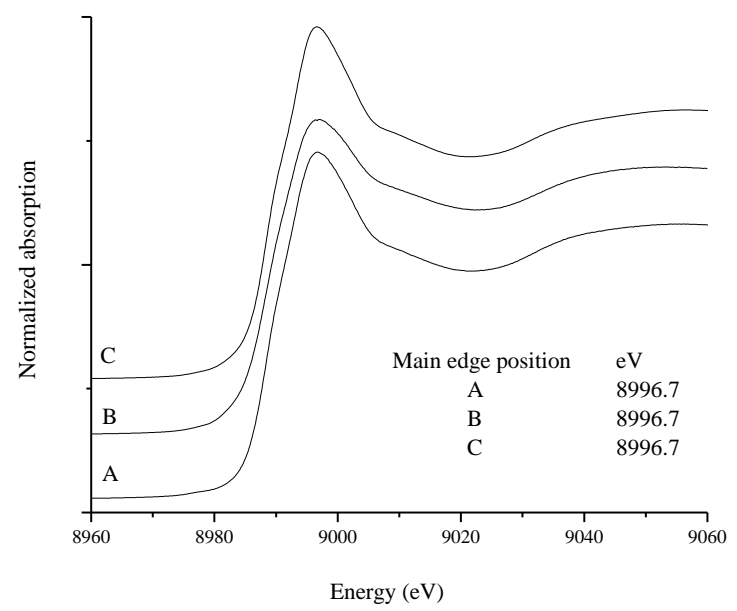

Figure $47 \mathrm{Cu}$ K-edge XANES spectra of A - SG-His-OMe-Cu(II), $\mathrm{B}$ - SG-Cys-OMe-Cu(II), C - SG-(Cys-OMe $)_{2}-\mathrm{Cu}(\mathrm{II})$.

The pre-edge feature, corresponding to $1 \mathrm{~s} \rightarrow 3 \mathrm{~d}$ transition, indicates that the anchored $\mathrm{Cu}(\mathrm{II})$ complexes are octahedral.

The Fourier-transformed EXAFS data (without phase correction) are shown in Figure 48, and the results of the fitting are reported in Table 16.

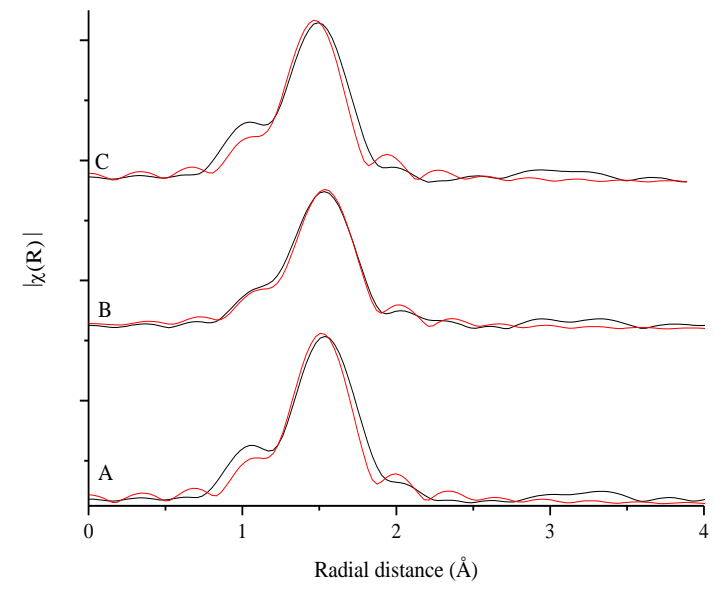

Figure 48 The Fourier transformed EXAFS data (without phase correction) of A - SG-His-OMe-Cu(II), B - SG-Cys-OMe-Cu(II), C - SG-(Cys-OMe) ${ }_{2}-\mathrm{Cu}(\mathrm{II})$, red line - fitted, black line - experimental. 
Table 16 Parameters deduced from the fitted EXAFS spectra $(\mathrm{N}$ - coordination number, $\mathrm{R}$ - bond length, $\sigma^{2}$ - Debye-Waller factor, $\Delta \mathrm{E}_{0}$ - energy shift, $\mathrm{R}$ factor - goodness of fit).

\begin{tabular}{lllllll}
\hline Sample & $\left(\mathrm{Cu}^{2+}-\right) \mathrm{X}$ & $\mathrm{N}$ & $\mathrm{R}(\AA)$ & $\sigma^{2}\left(\AA^{2}\right)$ & $\Delta \mathrm{E}_{0}(\mathrm{eV})$ & $\mathrm{R}$ factor \\
\hline SG-His-OMe-Cu(II) & $\mathrm{O} / \mathrm{N}$ & 6 & 1.94 & 0.0030 & 0.94 & 0.0256 \\
SG-Cys-OMe-Cu(II) & $\mathrm{O} / \mathrm{N}$ & 6 & 1.94 & 0.0034 & 1.10 & 0.0102 \\
$\mathrm{SG}-(\mathrm{Cys}-\mathrm{OMe})_{2}-\mathrm{Cu}(\mathrm{II})$ & $\mathrm{O} / \mathrm{N}$ & 6 & 1.94 & 0.0035 & 1.11 & 0.0284 \\
\hline
\end{tabular}

The EXAFS measurement revealed that in all cases six oxygen/nitrogen atoms were in the first coordination sphere. The $\mathrm{Cu}(\mathrm{II})-\mathrm{O} / \mathrm{N}$ bond distances are $1.94 \AA$ and the Debye-Waller factors are around $0.0033 \AA^{2}$. It indicates that the coordination environment of the complexes is similar. In SG-Cys-OMe-Cu(II) the thiolate sulphur is not coordinated, which may indicate the oxidation of cysteine molecules to cystine.

\subsubsection{FT-IR spectroscopy}

In the difference spectrum of SG-His-OMe-Cu(II), $\Delta=229 \mathrm{~cm}^{-1}$, suggesting that the carboxylate group acts as monodentate ligand (Figure 49, trace A). Adding Cprotected histidine in excess (Figure 49, trace B) resulted in the rearrangement of the surface-grafted ligand-poor complex. This spectrum is very similar to that of the pristine C-protected histidine, the carbonyl band $\left(1761 \mathrm{~cm}^{-1}\right)$ did not move, meaning that the carbonyl oxygen is not coordinated to the centre ion. In both cases the $\mathrm{Cu}$ (II)- $\mathrm{N}_{\text {imidazole }}$ vibration appeared at $261 \mathrm{~cm}^{-1}$ in the far IR range, indicating the coordination of the imidazole nitrogen (Figure 50, traces $\mathrm{A}$ and $\mathrm{B}$ ). 


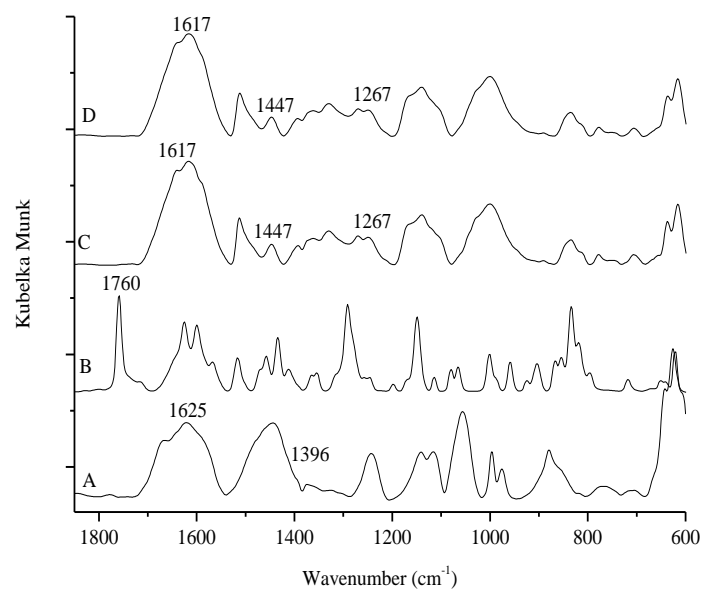

Figure 49 The IR spectra of A - SG-His-OMe-Cu(II), B - SG-His-OMe-Cu(II)-H-His-OMe, C - SG-Tyr-OMe-Cu(II), D - SG-Tyr-OMe-Cu(II)-H-Tyr-OMe.

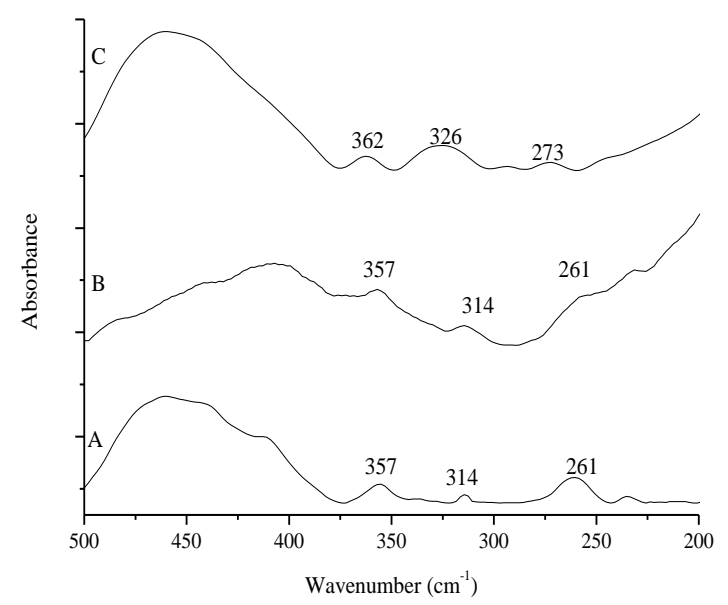

Figure 50 The far IR spectra of A - SG-His-OMe- $\mathrm{Cu}$ (II), B - SG-His-OMe-Cu(II)-H-His-OMe, C - SG-Tyr-OMe-Cu(II).

$\Delta=170 \mathrm{~cm}^{-1}$ for SG-Tyr-OMe-Cu(II) (Figure 49 , trace C), while it is $151 \mathrm{~cm}^{-1}$ for SG-Tyr-OMe, indicating that the carboxylate group appears in the coordination sphere of the metal ion as monodentate ligand. The phenolate oxygen is coordinated to the centre ion, since its vibration moved to $1267 \mathrm{~cm}^{-1}$ from $1280 \mathrm{~cm}^{-1}$. In the far IR range (Figure 50, trace $\mathrm{C}$ ), the bands at 362 and $273 \mathrm{~cm}^{-1}$ may suggest that the nitrogen of the amine is a coordinating group. The added H-Tyr-OMe (Figure 49, trace D) does not participate in the complexation, since the spectrum of the complex prepared under ligand-excess conditions is the same as it was observed for the complex synthesised under ligand-poor conditions. 
Putting together all the pieces of information, structural proposals for the surfacebound complexes are offered as follows:

SG-His-OMe-Cu(II)

$\mathrm{N}_{\text {imidazoleHissurf }} \mathrm{O}_{\text {carboxylateHissurf }} \mathrm{H}_{2} \mathrm{O}, \mathrm{H}_{2} \mathrm{O}, \mathrm{H}_{2} \mathrm{O}, \mathrm{H}_{2} \mathrm{O}$,

SG-His-OMe-Cu(II)-H-His-OMe

$\mathrm{N}_{\text {imidazoleHissurf }} \mathrm{O}_{\text {carboxylateHissurf }} \mathrm{N}_{\text {imidazoleHis }}, \mathrm{N}_{\text {imidazoleHis }} \mathrm{H}_{2} \mathrm{O}, \mathrm{H}_{2} \mathrm{O}$,

SG-Tyr-OMe-Cu(II)

$\mathrm{O}_{\text {carboxylateTyrsurf }} \mathrm{O}_{\text {phenolateTyrsurf }} \mathrm{N}_{\text {amineTyrsurf }} \mathrm{H}_{2} \mathrm{O}, \mathrm{H}_{2} \mathrm{O}, \mathrm{H}_{2} \mathrm{O}$.

The spectrum of SG-Cys-OMe-Cu(II) (Figure 51, trace A) is the same as that of $\mathrm{SG}-(\mathrm{Cys}-\mathrm{OMe})_{2}-\mathrm{Cu}$ (II) (Figure 51, trace B), indicating that the anchored cysteine molecules were oxidised to cystine in the presence of $\mathrm{Cu}(\mathrm{II})$, as was also suggested by EXAFS data. $\Delta=1601 \mathrm{~cm}^{-1}-1410 \mathrm{~cm}^{-1}=191 \mathrm{~cm}^{-1}$, which is very close to the value of the bidentate bridging mode, nevertheless, according to EXAFS data, monodentate ligation of the carboxylate group is more probable. Under ligand-excess conditions (Figure 51, trace C), the carbonyl oxygens are not involved in the complexation, since the positions of the band $\left(1744 \mathrm{~cm}^{-1}\right)$ are not shifted significantly. This means that the added C-protected cystine is coordinated via its amino nitrogens.

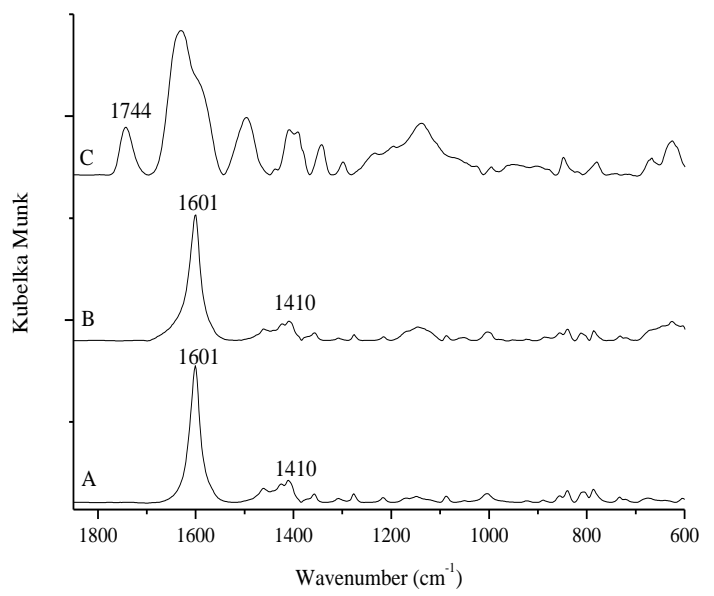

Figure 51 The IR spectra of A - SG-Cys-OMe-Cu(II), $\mathrm{B}-\mathrm{SG}-(\mathrm{Cys}-\mathrm{OMe})_{2}-\mathrm{Cu}(\mathrm{II})$, $\mathrm{D}-\mathrm{SG}-(\mathrm{Cys}-\mathrm{OMe})_{2}-\mathrm{Cu}(\mathrm{II})-(\mathrm{H}-\mathrm{Cys}-\mathrm{OMe})_{2}$.

The proposed coordination modes are the followings:

$\mathrm{SG}-(\mathrm{Cys}-\mathrm{OMe})_{2}-\mathrm{Cu}(\mathrm{II})$

$\mathrm{O}_{\text {carboxylate(Cys)2surf }} \mathrm{O}_{\text {carboxylate(Cys)2surf }} \mathrm{H}_{2} \mathrm{O}, \mathrm{H}_{2} \mathrm{O}, \mathrm{H}_{2} \mathrm{O}, \mathrm{H}_{2} \mathrm{O}$, 
SG-(Cys-OMe $)_{2}-\mathrm{Cu}(\mathrm{II})-(\mathrm{H}-\mathrm{Cys}-\mathrm{OMe})_{2}$

$\mathrm{O}_{\text {carboxylate(Cys)2surf }} \mathrm{O}_{\text {carboxylate(Cys)2surf }} \mathrm{N}_{\text {amino(Cys) } 2} \mathrm{~N}_{\text {amino(Cys)2 }} \mathrm{H}_{2} \mathrm{O}, \mathrm{H}_{2} \mathrm{O}$.

In Figure 52, trace A shows the spectrum of SG-His-OMe-Cu(II)-(H-Cys$\mathrm{OMe})_{2}$. The added C-protected cystine to $\mathrm{SG}-\mathrm{His}-\mathrm{OMe}-\mathrm{Cu}(\mathrm{II})$ rearranged the surface complex. The stretching vibration of the carbonyl bands $\left(1742 \mathrm{~cm}^{-1}\right)$ is equal to that of the free C-protected cystine, indicating that it was coordinated with the amino nitrogens. For SG-(Cys-OMe $)_{2}-\mathrm{Cu}(\mathrm{II})-\mathrm{H}-\mathrm{His}-\mathrm{OMe}$ (Figure 52, trace $\mathrm{B}$ ) the position of the carbonyl vibration is shifted by $20 \mathrm{~cm}^{-1}$ to $1741 \mathrm{~cm}^{-1}$, i.e., the carbonyl oxygen takes part in the complexation. In SG-His-OMe;(Cys-OMe $)_{2}-\mathrm{Cu}(\mathrm{II})$ the anchored amino acids are proposed to coordinate with their carboxylate groups and the imidazole nitrogen of histidine (Figure 51, trace C). Under ligand-excess conditions (Figure 51, trace D), the spectrum is very similar to the spectrum of C-protected histidine, no vibrations are seen corresponding to $\mathrm{C}$-protected cystine. It means that only histidine methylester is coordinated from the $1: 1$ mixture. The vibration at $1744 \mathrm{~cm}^{-1}$ can be attributed to the shifted carbonyl band of C-protected histidine.

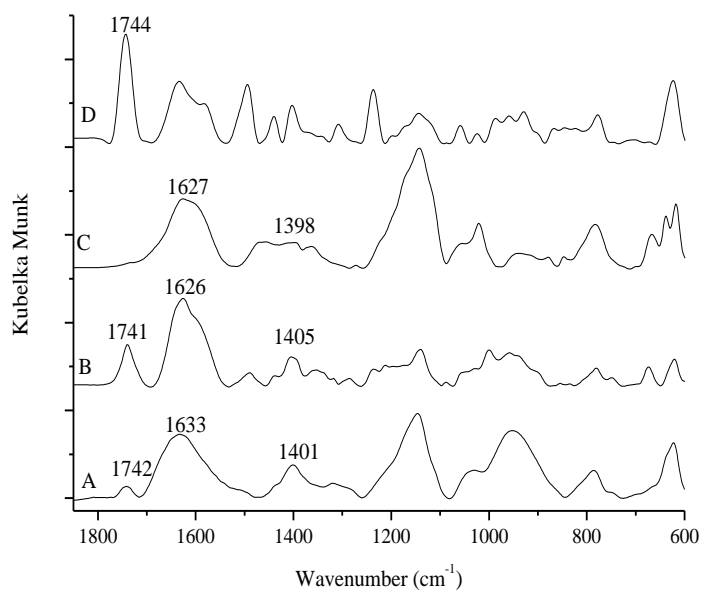

Figure 51 The IR spectra of A - SG-His-OMe-Cu(II)-(H-Cys-OMe $)_{2}$, $\mathrm{B}$ - SG-(Cys-OMe $)_{2}-\mathrm{Cu}(\mathrm{II})-\mathrm{H}-\mathrm{His}-\mathrm{OMe}, \mathrm{C}-\mathrm{SG}-\mathrm{His}-\mathrm{OMe}$;(Cys-OMe $)_{2}-\mathrm{Cu}(\mathrm{II})$, $\mathrm{D}$ - SG-His-OMe;(Cys-OMe $)_{2}-\mathrm{Cu}(\mathrm{II})-\mathrm{H}-\mathrm{His}-\mathrm{OMe} ;(\mathrm{H}-\mathrm{Cys}-\mathrm{OMe})_{2}$.

On the basis of the observations and the accumulated knowledge described at the complexes formed with uniform ligands, the following structures for the covalently immobilised complexes may be proposed:

SG-His-OMe-Cu(II)-(H-Cys-OMe $)_{2}$

$\mathrm{N}_{\text {imidazoleHissurf }} \mathrm{O}_{\text {carboxylateHissurf }} \mathrm{N}_{\text {amino(Cys) } 2} \mathrm{~N}_{\text {amino(Cys) } 2} \mathrm{H}_{2} \mathrm{O}, \mathrm{H}_{2} \mathrm{O}$, 
SG-(Cys-OMe $)_{2}-\mathrm{Cu}(\mathrm{II})-\mathrm{H}-\mathrm{His}-\mathrm{OMe}$

$\mathrm{O}_{\text {carboxylate(Cys)2surf }} \mathrm{O}_{\text {carboxylate(Cys)2surf }} \mathrm{N}_{\text {imidazoleHis }} \mathrm{O}_{\text {carbonylHis }} \mathrm{H}_{2} \mathrm{O}, \mathrm{H}_{2} \mathrm{O}$,

SG-His-OMe;(Cys-OMe $)_{2}-\mathrm{Cu}(\mathrm{II})$

$\mathrm{N}_{\text {imidazoleHissurf }} \mathrm{O}_{\text {carboxylateHissurf }} \mathrm{O}_{\text {carboxylate(Cys)2surf }} \mathrm{O}_{\text {carboxylate(Cys)2surf }} \mathrm{H}_{2} \mathrm{O}, \mathrm{H}_{2} \mathrm{O}$,

SG-His-OMe;(Cys-OMe $)_{2}-\mathrm{Cu}(\mathrm{II})-\mathrm{H}-\mathrm{His}-\mathrm{OMe} ;(\mathrm{H}-\mathrm{Cys}-\mathrm{OMe})_{2}$

$\mathrm{N}_{\text {imidazoleHissurf }} \mathrm{O}_{\text {carboxylateHissurf }} \mathrm{O}_{\text {carboxylate(Cys)2surf }} \mathrm{N}_{\text {imidazoleHis }} \mathrm{O}_{\text {carbonylHis }} \mathrm{H}_{2} \mathrm{O}$.

\subsubsection{Testing the superoxide dismutase activity}

All materials displayed catalytic activity, i.e., could catalyse the dismutation of the superoxide radical anion. Catalytic activities are not as good as it was found for $\mathrm{Mn}(\mathrm{II})$ and $\mathrm{Fe}(\mathrm{III})$ complexes (Table 17). The SOD activities of the best catalysts are minimum two magnitudes lower than that of the native enzyme. The most active anchored complex is SG-His-OMe;(Cys-OMe $)_{2}-\mathrm{Cu}(\mathrm{II})$.

Table 17 The SOD activities of the surface grafted complexes. The best catalyst is highlighted in red.

\begin{tabular}{lc}
\hline Materials & $\mathrm{IC}_{50}(\mu \mathrm{M})$ \\
\hline Cu,ZnSOD enzyme & 0.4 \\
SG-His-OMe-Cu(II) & 81 \\
SG-His-OMe-Cu(II)-H-His-OMe & 65 \\
SG-Tyr-OMe-Cu(II) & 60 \\
SG-(Cys-OMe $)_{2}-\mathrm{Cu}(\mathrm{II})$ & 92 \\
SG-(Cys-OMe $)_{2}-\mathrm{Cu}(\mathrm{II})-\mathrm{H}-(\mathrm{Cys}-\mathrm{OMe})_{2}$ & 82 \\
SG-His-OMe-Cu(II)-(H-Cys-OMe $)_{2}$ & 66 \\
SG-(Cys-OMe $)_{2}-\mathrm{Cu}(\mathrm{II})-\mathrm{H}-\mathrm{His}-\mathrm{OMe}$ & 177 \\
SG-His-OMe;(Cys-OMe $)_{2}-\mathrm{Cu}(\mathrm{II})$ & 41 \\
SG-His-OMe;(Cys-OMe $)_{2}-\mathrm{Cu}(\mathrm{II})-\mathrm{H}-\mathrm{His}-\mathrm{OMe} ;(\mathrm{H}-\mathrm{Cys}-\mathrm{OMe})_{2}$ & 132 \\
\hline
\end{tabular}

\subsubsection{Catalytic oxidation of cyclohexene}

The conversion and selectivity results of the immobilised catalysts in the oxidation of cyclohexene with peracetic acid in acetone are reported in Table 18. 
Table 18 The conversion and selectivity results of the oxidation of cyclohexene after $3 \mathrm{~h}$.

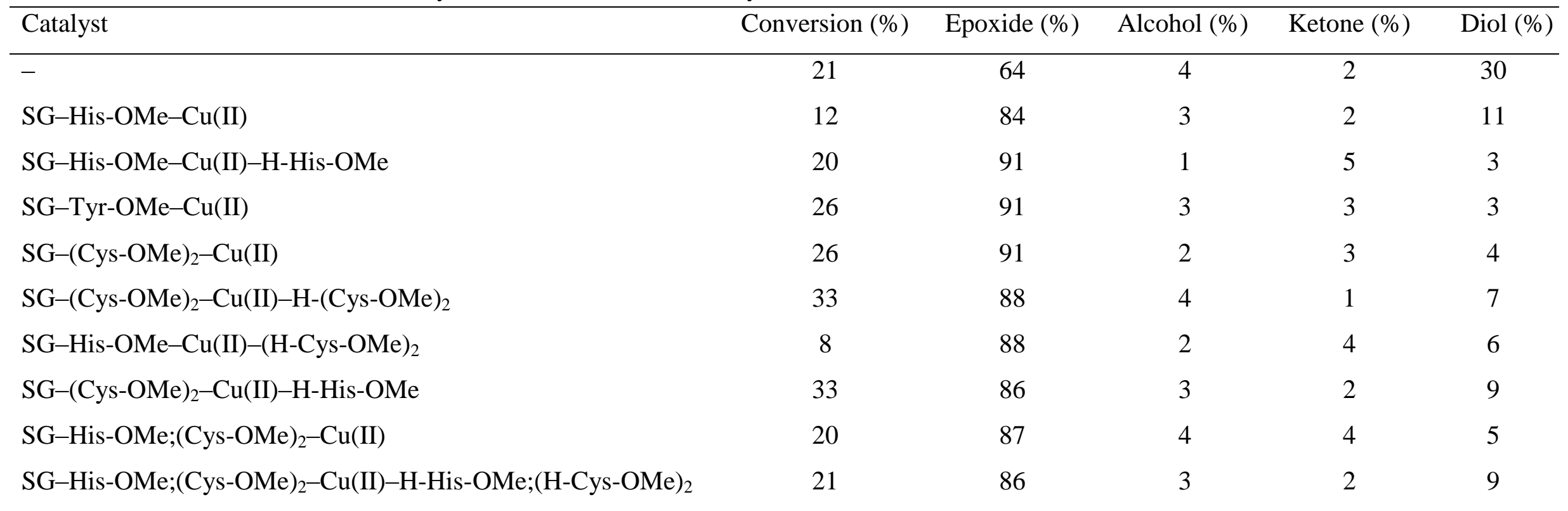


The conversion of the reactions are very low, in most cases it is around that of the uncatalysed reaction or even lower than that. Nevertheless, there is significant improvement in epoxide selectivities, they are always above $80 \%$, in some cases they are even more than $90 \%$. 


\section{Conclusions}

Many SOD-mimicking surface-anchored Mn(II)-, Fe(III)-, Co(II)-, Ni(II)- and $\mathrm{Cu}$ (II)-amino acid complexes were successfully constructed. It was possible to prepare the covalently anchored complexes with uniform and mixed ligands as well. Covalent anchoring gave good control over the mode of immobilisation.

Analytical measurements revealed that 1:1, 1:2 and 1:3 mixtures of complexes were formed on the surface of the support.

The coordination numbers and coordinating sites could be identified with the combination of XAS, EPR, UV-Vis DRS measurements, mid and far IR spectroscopies and chemical considerations. It was proven that the surface-grafted $\mathrm{Mn}(\mathrm{II}), \mathrm{Co}(\mathrm{II})$, $\mathrm{Ni}(\mathrm{II})$ and $\mathrm{Cu}$ (II) complexes were octahedral, while the $\mathrm{Fe}(\mathrm{III})$ complexes were square pyramidal. The major coordinating sites were proposed to be the carboxylate oxygen, the imidazole nitrogen, the phenolate oxygen and sulphur atom of the thiolate group. The other coordination sites depended on the conditions of the synthesis and the structures of the molecules. In all cases water molecules saturated the coordination sphere. In most cases under ligand-excess conditions the surface-anchored ligand-poor complexes were rearranged.

All the covalently anchored complexes were active in a SOD test reaction: they could catalyse the dismutation reaction of the superoxide radical anion. Catalytic activities differed widely though. In general they increased in the following order: $\mathrm{Cu}(\mathrm{II})<\mathrm{Ni}(\mathrm{II}) \sim \mathrm{Co}(\mathrm{II})<\mathrm{Mn}$ (II) $<\mathrm{Fe}$ (III). The activity of some $\mathrm{Fe}$ (III) complexes was only one magnitude lower that of the native $\mathrm{Cu}, \mathrm{ZnSOD}$ enzyme.

The applied SOD mimicking complexes displayed catalytic activity in the oxidation of cyclohexene and all of them were selective to cyclohexene oxide formation. There was no leaching of the ligands or the complex either during the reaction. Some of the best catalysts were reused two times without significant loss in the catalytic activity and selectivity. The activities and selectivities were depended on the applied metal ion and were not depended on the coordinating groups. The efficiency of the catalyst increased in the following order: $\mathrm{Cu}$ (II) $<\mathrm{Ni}$ (II) $<<\mathrm{Mn}(\mathrm{II})<\mathrm{Fe}$ (III). This order was the same as it was in the SOD test reaction in general. The mechanism of the reaction was not investigated but the bigger difference between $\mathrm{Cu}(\mathrm{II}) / \mathrm{Ni}$ (II) and $\mathrm{Mn}(\mathrm{II}) / \mathrm{Fe}$ (III) suggested different mechanism for the oxidation. One of the coordinated water molecule is supposed to be replaced by the peroxidic oxygen donor oxidant, 
forming a (hydro)peroxo-metal species in both cases. For $\mathrm{Cu}$ (II) and $\mathrm{Ni}$ (II) complexes, this adduct may epoxidise cyclohexene directly, while for $\mathrm{Mn}$ (II) and $\mathrm{Fe}(\mathrm{III})$ complexes the $\mathrm{O}-\mathrm{O}$ bond may be cleaved heterolytically to form high-valent metal-oxo species as an active intermediate, which is responsible for the epoxidation.

Immobilisation of transition metal-amino acid complexes is a viable route for preparing efficient electron transfer catalysts since there are very active and selective catalysts that can be easily recovered and recycled. They show the promise of becoming efficient catalysts in fine chemical industry. 


\section{References}

[1] P.C. Champe, R.A. Harvey, D.R. Ferrier, In: Lippincott's illustrated reviews: biochemistry, 3rd ed., Lippincott Williams \& Wilkins, Baltimore and Philadelphia, 2005, pp. 53-56.

[2] R.H. Garrett, C.M. Grisham, In: Biochemistry, 4th ed., Brooks/Cole, Boston, 2010, pp. 409-410.

[3] E. Fischer, Ber. Chem. Ges. Berl. 27 (1894) 2985.

[4] D.E. Koshland, Proc. Natl. Acad. Sci. 44 (1958) 98.

[5] Enzyme Nomenclature, Academic Press, San Diego, 1992.

[6] I. Fridovich, J. Biol. Chem. 272 (1997) 18515.

[7] A.-F. Miller, D.L. Sorkin, Comments Mol. Cell. Biophys. 9 (1997) 1.

[8] J.A. Tainer, E.D. Getzoff, J.S. Richardson, D.C. Richardson, Nature 306 (1983) 284.

[9] A.-F. Miller, Wiley, Chichester, 2001, pp. 668-682.

[10] G.E.O. Borgstahl, H.E. Parge, M.J. Hickey, W.F. Beyer Jr., R.A. Hallewell, J.A. Tainer, Cell 71 (1992) 107.

[11] H.D. Youn, E.J. Kim, J.H. Roe, Y.C. Hah, S.O. Kang, Biochem. J. 318 (1996) 889.

[12] A. Battistoni, G. Rotilio, FEBS Letters 374 (1995) 199.

[13] Y. Bourne, S.M. Redford, H.M. Steinmann, J.R. Lepock, J.A. Tainer, E.D. Getzoff, Proc. Natl. Acad. Sci. USA 93 (1996) 12774.

[14] Y.L. Chen, S. Park, R.W. Thornburg, L.B. Tabatabai, A. Kintanar, Biochem. 34 (1995) 12265.

[15] J.A. Tainer, E.D. Getzoff, K.M. Beem, J.S. Richardson, D.C. Richardson, J. Mol. Biol. 160 (1982) 181.

[16] K. Djinovic, G. Gatti, A. Coda, L. Antolini, G. Pelosi, A. Desideri, M. Falconi, F. Marmocchi, G. Rotilio, M. Bolognesi, J. Mol. Biol. 225 (1992) 791.

[17] L.M. Murphy, R.W. Strange, S.S. Hasnain, Structure 5 (1997) 371.

[18] M.E. McAdam, E.M. Fielden, F. Lavelle, L. Calabrese, D. Cocco, G. Rotilio, Biochem. J. 167 (1977) 271.

[19] W.C. Stallings, K.A. Pattridge, R.K. Strong, M.L. Ludwig, J. Biol. Chem. 259 (1984) 10695.

[20] M.L. Ludwig, A.L. Metzger, K.A. Pattridge, W.C. Stallings, J. Mol. Biol. 219 (1991) 335.

[21] M.S. Lath, M.M. Dixon, K.A. Pattridge, W.C. Stallings, J.A. Fee, M.L. Ludwig, Biochem. 34 (1995) 1646.

[22] W.-G. Han, T. Lovell, L. Noodleman, Inorg. Chem. 41 (2002) 205.

[23] A.-F. Miller, F. Padmakumar, D. Sorkin, A. Karapetian, C.K. Vance, J. Inorg. Biochem. 93 (2003) 71.

[24] B. Palenic, B. Brahamsha, F.W. Larimer, M. Land, L. Hauser, P. Chain, J. Lamerdin, W. Regala, E.E. Allen, J. McCarren, I. Paulsen, A. Dufresne, F. Partensky, E.A. Webb, J. Waterbury, Nature 424 (2003) 1037.

[25] S.B. Choudhury, J.W. Lee, G. Davidson, Y.I. Yim, K. Bose, M.L. Sharma, S.O. Kang, D.E. Cabelli, M.J. Maroney, Biochem. 38 (1999) 3744.

[26] D.P. Barondeau, C.J. Kassmann, C.K. Bruns, J.A. Tainer, E.D. Getzoff, Biochem. 43 (2004) 8038.

[27] J. Wuerges, J.-W. Lee, Y.-I. Yim, H.-S. Yim, S.-O. Kang, K.D. Carugo, Proc. Natl. Acad. Sci. 101 (2004) 8569. 
[28] I. Pálinkó, In: Inorganic Biochemistry: Research Progress, Nova Science Publishers Inc., 2008, pp. 281-303.

[29] D.P. Riley, Chem. Rev. 99 (1999) 2573.

[30] R.F. Pasternack, B. Halliwell, J. Am. Chem. Soc. 101 (1979) 1026.

[31] R. Herchel, Z. Sindelár, Z. Trávnícek, R. Zboril, J. Vanco, Dalton Trans. 44 (2009) 9870.

[32] G.-F. Liu, M. Filipovic, F.W. Heinemann, I. Ivanovic-Burmazovic, Inorg. Chem. 46 (2007) 8825.

[33] S. Miriyala, I. Spasojevic, A. Tovmasyan, D. Salvemini, Z. Vujaskovic, D. St. Clair, I. Batinic-Haberle, Biochim. Biophys. Acta 1822 (2012) 794.

[34] I. Szilágyi, I. Labádi, K. Hernádi, I. Pálinkó, N.V. Nagy, L. Korecz, A. Rockenbauer, Z. Kele, T. Kiss, J. Inorg. Biochem. 99 (2005) 1619.

[35] A. Barik, B. Mishra, A. Kunwar, R.M. Kadam, L. Shen, S. Dutta, S. Padhye, A.K. Satpati, H.-Y. Zhang, K.I. Priyadarsini, Eur. J. Med. Chem. 42 (2007) 431.

[36] M. Devereux, D. O'Shea, M. O'Connor, H. Grehan, G. Connor, M. McCann, G. Rosair, F. Lyng, A. Kellett, M. Walsh, D. Egan, B. Thati, Polyhedron 26 (2007) 4073.

[37] J.S. Pap, B. Kripli, V. Bányai, M. Giorgi, L. Korecz, T. Gajda, D. Árus, J. Kaizer, G. Speier, Inorg. Chim. Acta 376 (2011) 158.

[38] A.E.-M.M. Ramadan, J. Mol. Struct. 1015 (2012) 56.

[39] R.N. Patel, S. Kumar, K.B. Pandeya, J. Inorg. Biochem. 89 (2002) 61.

[40] T. Piacham, C. Isarankura-Na-Ayudhya, C. Nantasenamat, S. Yainoy, L. Ye, L. Bülow, V. Prachayasittikul, Biochem. Biophys. Res. Commun. 341 (2006) 925.

[41] K.M. Koeller, C.H. Wong, Nature 409 (2001) 232.

[42] U. Hanefeld, L. Gardossi, E. Magner, Chem.Soc.Rev. 38 (2009) 453.

[43] U.T. Bornscheuer, Angew. Chem. Int. Ed. 42 (2003) 3336.

[44] D.J. Xuereb, R. Raja, Catal. Sci. Technol. 1 (2011) 517.

[45] J.A. Labinger, J. Mol. Catal. A: Chem. 220 (2004) 27.

[46] M. Luechinger, A. Kienhöfer, G.D. Pirngruber, Chem. Mater. 18 (2006) 1330.

[47] K. Suzuki, P.D. Oldenburg, L. Que Jr., Angew. Chem., Int. Ed. 47 (2008) 1887.

[48] B.M. Weckhuysen, J. Am. Chem. Soc. 128 (2006) 3208.

[49] N. End, K.-U. Schöning, Top. Curr. Chem. 242 (2004) 273.

[50] N. Miletic, A. Nastasovic, K. Loos, Bioresour. Technol. 115 (2012) 126.

[51] L. Betancor, H.R. Luckarift, Trends Biotechnol. 26 (2008) 566.

[52] G. Bayramoğlu, M. Yılmaz, A.Ü. Şenel, M.Y. Arıca, Biochem. Eng. J. 40 (2008) 262.

[53] C.-H. Lee, T.-S. Lin, C.-Y. Mou, Nano Today 4 (2009) 165.

[54] S. Akgöl, Y. Kaçar, S. Özkara, H. Yavuz, A. Denizli, M.Y. Arica, J. Mol. Catal. B: Enzym. 15 (2001) 197.

[55] I.U. Castro, F. Stüber, A. Fabregat, J. Font, A. Fortuny, C. Bengoa, J. Hazard. Mater. 163 (2009) 809.

[56] S.T. Castaman, S. Nakagaki, R.R. Ribeiroa, K.J. Ciuffi, S.M. Drechsel, J. Mol. Catal. A: Chem. 300 (2009) 89.

[57] I. Szilágyi, I. Labádi, K. Hernadi, I. Pálinkó, T. Kiss, J. Mol. Struct. 744-747 (2005) 495.

[58] J. Lalonde, A. Margolin, In: Enzyme Catalysis in Organic Chemistry, 2nd ed., Wiley-VCH, Weinheim, 2008, pp. 163-184.

[59] M. Fraile, I. Garci, A. Mayoral, Chem. Rev. 109 (2009) 360.

[60] R. Torres, C. Ortiz, B.C.C. Pessela, J.M. Palomo, C. Mateo, J.M. Guisan, R. Fernandez-Lafuente, Enzyme Microb. Technol. 39 (2006) 167. 
[61] M. Fuentes, J.V. Maguise, B.C. Pessela, O. Abian, R. Fernandez-Lafuente, C. Mateo, J.M. Guisan, Biotechnol. Progr. 1 (2004) 284.

[62] C. Lei, T.A. Soares, Y. Shin, J. Liu, E.J. Ackerman, Nanotech 19 (2008) 125102.

[63] C. Lei, Y. Shin, J.K. Magnuson, G. Fryxell, L.L. Lasure, D.C. Elliot, Nanotech 17 (2006) 5531.

[64] F. Farzaneh, M. Majidian, M. Ghandi, J. Mol. Catal. A: Chem. 148 (1999) 227.

[65] B.M. Weckhuysen, A.A. Verberckmoes, L. Fu, R.A. Schoonheydt, J. Phys. Chem. 100 (1996) 9456.

[66] F. Farzaneh, S. Sadeghi, L. Turkian, M. Ghandi, J. Mol. Catal. A: Chem. 132 (1998) 255.

[67] J.G. Mesu, T. Visser, A.M. Beale, F. Soulimani, B.M. Weckhuysen, Chem.Eur. J. 12 (2006) 7167.

[68] F. Farzaneh, S. Sohrabi, M. Ghiasi, M. Ghandi, V. Mehdi Ghandi, J. Porous Mater. 20 (2013) 267.

[69] I. Szilágyi, I. Labádi, K. Hernádi, I. Pálinkó, I. Fekete, L. Korecz, A. Rockenbauer, T. Kiss., New J. Chem. 29 (2005) 740.

[70] N.H. Gutmann, L. Spiccia, T.W. Turney, J. Mater. Chem. 10 (2000) 1219.

[71] M. Halma, K.A.D. de Freitas Castro, C. Taviot-Gueho, V. Prévot, C. Forano, F. Wypych, S. Nakagaki, J. Catal. 257 (2008) 233.

[72] T.C.O. Mac Leod, M.N. Kopylovich, M.F.C. Guedes da Silva, K.T. Mahmudov, A.J.L. Pombeiro, Appl. Catal., A (2012) 15.

[73] Y.-C. Fang, H.-C. Lin, I.-J. Hsu, T.-S. Lin, C.-Y. Mou, J. Phys. Chem. C 115 (2011) 20639.

[74] A. Baso, L.D. Martin, C. Ebert, L. Gardossi, P. Linda, F. Sibilla, Tetrahedron Lett. 44 (2003) 5889.

[75] H.H.P. Yiu, P.A. Wright, J. Mater. Chem. 15 (2005) 3690.

[76] C. Ispas, I. Sokolov, S. Andreescu, Anal. Bioanal. Chem. 393 (2009) 543.

[77] Ö. Alptekin, S.S. Tükel, D. Yildirim, D. Alagöz, J. Mol. Catal. B: Enzym. 64 (2010) 177.

[78] C. Song, L. Sheng, X. Zhang, Appl. Microbiol. Biotechnol. 1 (2012) 123.

[79] V.B. Valodkar, G.L. Tembe, M. Ravindranathan, R.N. Ram, H.S. Rama, J. Mol. Catal. A: Chem. 208 (2004) 21.

[80] S.M. Islam, M. Mobarok, P. Mondal, A.S. Roy, N. Salam, D. Hossain, S. Mondal, Transition Met. Chem. 37 (2012) 97.

[81] I. Szilágyi, O. Berkesi, M. Sipiczki, L. Korecz, A. Rockenbauer, I. Pálinkó, Catal. Lett. 127 (2009) 239.

[82] J.M. Thomas, R. Raja, Acc. Chem. Res. 41 (2008) 708.

[83] C. Vartzouma, E. Evaggellou, Y. Sanakis, N. Hadjiliadis, M. Louloudi, J. Mol. Catal. A: Chem. 263 (2007) 77.

[84] D. Zois, C. Vartzouma, Y. Deligiannakis, N. Hadjiliadis, L. Casella, E. Monzani, M. Louloudi, J. Mol. Catal. A: Chem. 261 (2007) 306.

[85] G.D. Pirngruber, L. Frunz, M. Lüchinger, Phys. Chem. Chem. Phys. 11 (2009) 2928.

[86] D. Tang, W. Zhang, Y. Zhang, Z.-A. Qiao, Y. Liu, Q. Huo, J. Colloid Interface Sci. 356 (2011) 262.

[87] R.K. Sharma, D. Rawat, Inorg. Chem. Commun. 17 (2012) 58.

[88] D. Avnir, T. Coradin, O. Lev, J. Livage, J. Mater. Chem. 16 (2006) 1013.

[89] M.T. Reetz, P. Tielmann, W. Wiesenhöfer, W. Könen, A. Zonta, Adv. Synth. Catal. 345 (2003) 717. 
[90] F. Axthelm, O. Casse, W.H. Koppenol, T. Nauser, W. Meier, C.G. Palivan, J. Phys. Chem. B 112 (2008) 8211.

[91] D.E. De Vos, R.F. Parton, B.M. Weckhuysen, R.A. Jacobs, J. Incl. Phen. Mpl. Recogn. Chem. 21 (1995) 185.

[92] E.F. Murphy, L. Schmid, T. Bürgi, M. Maciejewski, A. Baiker, Chem. Mater. 13 (2001) 1296.

[93] R.A. Sheldon, Adv. Synth. Catal. 349 (2007) 1289.

[94] F. D'Agnillo, T.M. Chang, Artif. Cells, Blood Substitues, Immobilization Biotechnol. 5 (1993) 609.

[95] Y. Zhang, J. Zhao, L. He, D. Zhao, S. Zhang, Mic. Mes. Mater. 94 (2006) 159.

[96] J. Gao, Y. Chen, B. Han, Z. Feng, C. Li, N. Zhou, Z. Gao, J. Mol. Catal., A 210 (2004) 197.

[97] S. Samantaray, K. Parida, Catal. Commun. 6 (2005) 578.

[98] S. Bhattacharjee, J.A. Anderson, J. Mol. Catal., A 249 (2006) 103.

[99] J. Jiang, K. Ma, Y. Zheng, S. Cai, R. Li, J. Ma, Appl. Clay Sci. 45 (2009) 117.

[100] R. Noyori, M. Aoki, K. Sato, Chem. Commun. (2003) 1977.

[101] T. Punniyamurthy, L. Rout, Coord. Chem. Rev. 252 (2008) 134.

[102] H. Shi, Z. Zhang, Y. Wang, J. Mol. Catal., A 238 (2005) 13.

[103] K.-P. Ho, W.-L. Wong, K.-M. Lam, C.-P. Lai, T.H. Chan, K.-Y. Wong, Chem. Eur. J. 14 (2008) 7988.

[104] A. Decker, E.I. Solomon, Curr. Opin. Chem. Biol. 9 (2005) 152.

[105] P. Chutia, S. Kato, T. Kojima, S. Satokawa, Polyhedron 28 (2009) 370.

[106] A. Serafimidou, A. Stamatis, M. Louloudi, Catal. Commun. 9 (2008) 35.

[107] A. Stamatis, P. Doutsi, K.C. Christoforidis, Y. Deligiannakis, M. Louloudi, J. Mol. Catal., A 297 (2009) 44.

[108] T.J. Terry, T.D.P. Stack, J. Am. Chem. Soc. 130 (2008) 4945.

[109] J. Tang, Y. Zu, W. Hou, L. Wang, J. Wang, M. Jia, W. Zhang, W.R. Thiel, J. Mol. Catal., A 335 (2012) 201.

[110] G. Bilis, K.C. Christoforidis, Y. Deligiannakis, M. Louloudi, Catal. Today 157 (2010) 101.

[111] S. Khare, R. Chokhare, J. Mol. Catal., A 344 (2011) 83.

[112] H. Sohrabi, M. Esmeeli, F. Farzaneh, M. Ghandi, J. Incl. Phenom. Macromol. 54 (2006) 23.

[113] S.M. Islam, P. Mondal, S. Mukherjee, A.S. Roy, A. Bhaumik, Polym. Adv. Technol. 22 (2011) 933.

[114] B.M. Weckhuysen, A.A. Verberckmoes, I.P. Vannijvel, J.A. Pelgrims, P.L. Buskens, P.A. Jacobs, R.A. Schoonheydt, Angew. Chem. Int. Ed. Engl. 34 (1995) 2652.

[115] N. Malumbazo, S.F. Mapoline, J. Mol. Catal., A 312 (2009) 70.

[116] I. Kuzniarska-Biernacka, K. Biernacki, A.L. Magalhaes, A.M. Fonseca, I.C. Neves, J. Catal. 278 (2011) 102.

[117] G. Olason, D.C. Sherrington, React. Funct. Polym. 42 (1999) 163.

[118] M. Salavati-Niasari, M. Hassani-Kabutarkhani, F. Davar, Catal. Commun. 7 (2006) 955.

[119] A.B.P. Lever, In: Inorganic Electronic Spectroscopy, 2nd ed., Elsevier, Amsterdam, 1984.

[120] A. Rockenbauer, L. Korecz, Appl. Magn. Reson. 10 (1996) 29.

[121] P.F. Rapheal, E. Manoj, M.R. Prathapachandra Kurup, Polyhedron 26 (2007) 5088. 
[122] S. Carlson, M. Clausen, L. Gridneva, B. Sommarin, C.J. Svensson, J. Synchrotron Radiat. 13 (2006) 359.

[123] B. Ravel, M. Newville, J. Synchrotron Radiat. 12 (2005) 537.

[124] J.J. Rehr, J.M. DeLeon, S.I. Zabinsky, R.C. Albers, J. Am. Chem. Soc. 113 (1991) 5135.

[125] S.K. Papageorgiou, E.P. Kouvelos, E.P. Favvas, A.A. Sapadilis, G.E. Romanos, F.K. Katsaros, Carbohydr. Res. 345 (2010) 469.

[126] S.A. Abdel-Latif, H.B. Hassib, Y.M. Issa, Spectrochim. Acta, Part A 67 (2007) 950.

[127] T. Miura, T. Satoh, H. Takeuchi, Biochim. Biophys. Acta 1384 (1998) 171.

[128] C. Beauchamp, I. Fridovich, Anal. Biochem. 44 (1971) 276.

[129] S.F. Parker, K. Shankland, J.C. Sprunt, U.A. Javasooriva, Spectrochim. Acta, A 53 (1997) 2333.

[130] J.J. Klaassen, I.D. Darkhalil, J.R. Durig, http://hdl.handle.net/1811/52414 (last visit: 23.06.2013).

[131] G.W. Rayner Canham, A.B.P. Lever, Can. J. Chem. 50 (1972) 3866.

[132] B.C. Cornilesen, K. Nakamoto, J. Inorg. Nucl. Chem. 36 (1974) 2467.

[133] L.A. Cosby, Vibrational Assignments for Malonic Acid: Kinetics of Thermal Decarboxylation and Reactions of Malonic Acid in Alkali Halides, PhD Dissertation, West Virginia University, Morgantown, United States, 1969, pp. 22.

[134] S.K. Misra, Physica B Condens. Matter 44 (1994) 276.

[135] Y. Tao, J.E. Shokes, W.C. McGregor, R.A. Scott, R.C. Holz, J. Inorg. Biochem. 111 (2012) 157.

[136] E. Montarges-Pelletier, V. Chardot, G. Echevarria, L.J. Michot, A. Bauer, J.-L. Morel, Phytochem. 69 (2008) 1695.

[137] D.R. Fernando, T. Mizuno, I.E. Woodrow, A.J.M. Baker, R.N. Collins, New Phytol. 188 (2010) 1014.

[138] D.E. De Vos, B.F. Sels, P.A. Jacobs, Cattech 6 (2002) 14.

[139] Y. Wang, Q. Zhang, T. Shishido, K. Takehira, J. Catal. 2009 (2002) 186.

[140] J.L. DuBois, P. Mukherjee, T.D.P. Stack, B. Hedman, E.I. Solomon, K.O. Hodgson, J. Am. Chem. Soc. 122 (2000) 5775.

[141] K.M. Padden, J.F. Krebs, C.E. MacBeth, R.C. Scarrow, A.S. Borovic, J. Am. Chem. Soc. 123 (2001) 1072.

[142] G.J. Colpas, M.J. Maroney, C. Bagyinka, M. Kumar, W.S. Willis, S.L. Suib, N. Baidya, P.K. Mascharak, Inorg. Chem. 30 (1991) 920. 


\section{Magyar nyelvü összefoglaló (Hungarian summary)}

Munkám során sikeresen állítottam elő hordozón rögzített, SOD enzimutánzó, Mn(II)-, Fe(III)-, Co(II)-, Ni(II)- és Cu(II)-aminosav komplexeket. Egyfajta és vegyes ligandumot tartalmazó komplexeket alakítottam ki kovalens kötéssel klórpropilezett szilikagélen.

Az analitikai mérések alapján megállapítottam, hogy a felületen vegyes összetételü, 1:1, 1:2 és 1:3 arányú komplexek helyezkednek el.

A koordinációs számokat és a koordinálódó csoportokat XAS, ESR, UV-Vis DRS, közép és távoli IR spektroszkópia alkalmazásával és kémiai meggondolások alapján határoztam meg. Bebizonyítottam, hogy a Mn(II)-, Co(II)-, Ni(II)- és Cu(II)tartalmú felületi komplexek oktaéderesek, míg a Fe(III)-tartalmúak négyzetesen piramisosak. A karboxilátoxigén, az imidazolnitrogén, a fenolátoxigén és a tiolátkén minden esetben részt vesz a komplexképzésben, az aminonitrogén és a karboniloxigén koordinációja függ az alkalmazott körülményektől. A koordinációs szférát minden esetben vízmolekulák telítik. A legtöbb esetben a ligandumban gazdag körülmények alkalmazásának hatására megváltozik a ligandumban szegény felületi komplex szerkezete.

Minden immobilizált komplex mutatott SOD aktivitást, azaz katalizálta a szuperoxid gyökanionok dizmutációját az alkalmazott tesztreakcióban. A katalitikus aktivitások széles körben változtak. Általánosságban elmondható, hogy a következő sorrendben nőttek az aktivitások: $\mathrm{Cu}$ (II) < Ni(II) Co(II) < $\mathrm{Mn}$ (II) < Fe(III). Néhány felületi $\mathrm{Fe}(\mathrm{III})$ komplex esetén sikerült egy nagyságrendre megközelíteni a Cu,ZnSOD enzim aktivitását.

Az alkalmazott SOD enzimutánzó rögzített komplexek katalizálták a ciklohexén oxidációját, epoxidszelektivitást mutatva. A reakció során nem oldódott le a komplex a felületről. A legjobb katalizátorokat sikerült kétszer újrafelhasználni, jelentős aktivitás és szelektivitásvesztés nélkül. Az aktivitás és szelektivitás értékek függtek az alkalmazott fémiontól, viszont függetlenek voltak a koordinálódó csoportoktól. A katalizátorok hatékonysága a következő sorrendben nőtt: $\mathrm{Cu}(\mathrm{II})<\mathrm{Ni}$ (II) $<<\mathrm{Mn}(\mathrm{II})<$ Fe(III). Általánosságban elmondható, hogy ez a sorrend megegyezik a SOD tesztreakcióban tapasztaltakkal. A reakció mechanizmusát ugyan nem vizsgáltam, de a $\mathrm{Cu}(\mathrm{II}) / \mathrm{Ni}(\mathrm{II})$ és $\mathrm{Mn}(\mathrm{II}) / \mathrm{Fe}(\mathrm{III})$ komplexek aktivitása közti nagyobb különbség arra utalhat, hogy a reakció mechanizmusa eltérő. Valószínüleg mindkét esetben az 
oxidálószer egy koordinálódó vízmolekula helyére lép be, (hidro)peroxo intermediert képezve. A $\mathrm{Cu}(\mathrm{II})$ és $\mathrm{Ni}(\mathrm{II})$ komplexek esetén ez a komplex közvetlenül oxidálhatja a ciklohexént, míg a Mn(II)- and Fe(III)-tartalmú komplexek esetén az O-O kötés heterolitikusan hasadhat és az így keletkező fém-oxo komplex vehet rész az epoxidációban.

Redox-aktív átmeneti fémion-aminosav komplexek immobilizálásával aktív, szelektív és újrafelhasználható katalizátorokat állítottam elö, melyek alkalmasak lehetnek finomkemikáliák ipari előállítására. 


\section{Acknowledgements}

Firstly, let me gratefully acknowledge the immense support and help of Dr. István Pálinkó and Dr. Pál Sipos. My grateful thanks go to them for both the theoretical and practical encouragement and teaching that I have received from them during the years I have spent in their unique research group.

Let me also gratefully acknowledge the efforts of Dr. János T. Kiss and Dr. Ottó Berkesi for their valuable insights and suggestions regarding FT-IR spectroscopy. I wish to express my sincere thanks to Dr. Nóra May, Dr. Imre Dékány and Sebők Dániel for their measurements.

Many thanks go to all members of the Department of Inorganic and Analytical Chemistry and the Material and Solution Structure Research Group.

I thank to all who helped me in any aspects in- and outside of the University of Szeged.

Many thanks to my family and friends for the tremendous support they gave me.

Finally, I would like to acknowledge the most important person in my life - my husband. He has been a constant source of strength and inspiration. 